\title{
NTP TECHNICAL REPORT ON THE TOXICITY STUDIES OF \\ 5-AMINO-O-CRESOL \\ (CASRN 2835-95-2) \\ ADMINISTERED Dermally tO \\ F344/NTAC RATS AND \\ B6C3Fl/N MICE
}

NTP TOX 89

NOVEMBER 2015 


\section{NTP Technical Report on the Toxicity Studies of 5-Amino-o-cresol (CASRN 2835-95-2) Administered Dermally to F344/NTac Rats and B6C3F1/N Mice}

Toxicity Report 89

November 2015

National Toxicology Program

Public Health Service

U.S. Department of Health and Human Services

ISSN: 2378-8992

Research Triangle Park, North Carolina, USA 


\section{Foreword}

The National Toxicology Program (NTP) is an interagency program within the Public Health Service (PHS) of the Department of Health and Human Services (HHS) and is headquartered at the National Institute of Environmental Health Sciences of the National Institutes of Health (NIEHS/NIH). Three agencies contribute resources to the program: NIEHS/NIH, the National Institute for Occupational Safety and Health of the Centers for Disease Control and Prevention (NIOSH/CDC), and the National Center for Toxicological Research of the Food and Drug Administration (NCTR/FDA). Established in 1978, NTP is charged with coordinating toxicological testing activities, strengthening the science base in toxicology, developing and validating improved testing methods, and providing information about potentially toxic substances to health regulatory and research agencies, scientific and medical communities, and the public.

The Toxicity Study Report series began in 1991. The studies described in the Toxicity Study Report series are designed and conducted to characterize and evaluate the toxicologic potential of selected substances in laboratory animals (usually two species, rats and mice). Substances selected for NTP toxicity studies are chosen primarily on the basis of human exposure, level of production, and chemical structure. The interpretive conclusions presented in the Toxicity Study Reports are based only on the results of these NTP studies. Extrapolation of these results to other species, including characterization of hazards and risks to humans, requires analyses beyond the intent of these reports. Selection per se is not an indicator of a substance's toxic potential. NTP conducts its studies in compliance with its laboratory health and safety guidelines and FDA Good Laboratory Practice Regulations and must meet or exceed all applicable federal, state, and local health and safety regulations. Animal care and use are in accordance with the Public Health Service Policy on Humane Care and Use of Animals. Studies are subjected to retrospective quality assurance audits before being presented for public review.

NTP Toxicity Study Reports are indexed in National Center for Biotechnology Information (NCBI) Bookshelf and are available free of charge electronically on the NTP website (http://ntp.niehs.nih.gov). Toxicity data are available through NTP's Chemical Effects in Biological Systems (CEBS) database: https://www.niehs.nih.gov/research/resources/databases/index.cfm. 


\section{Table of Contents}

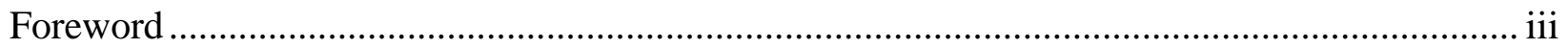

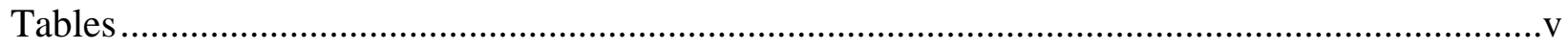

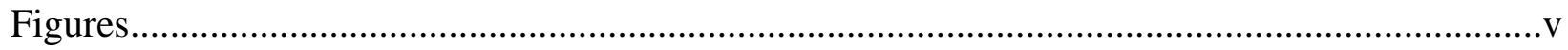

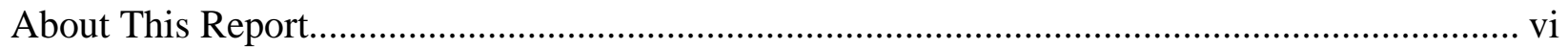

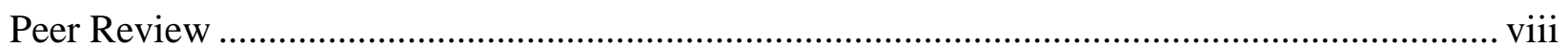

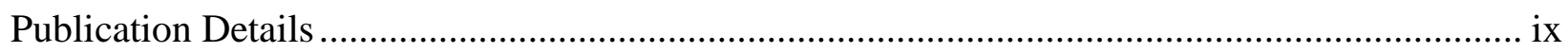

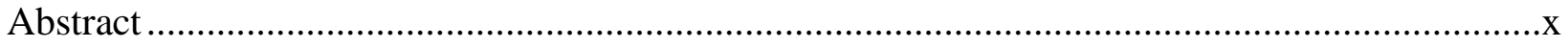

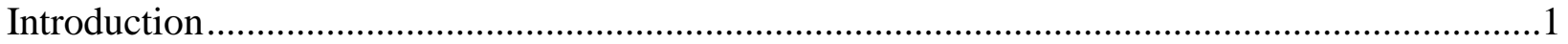

Chemical and Physical Properties ..................................................................................

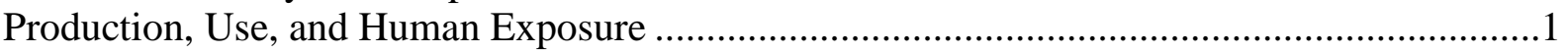

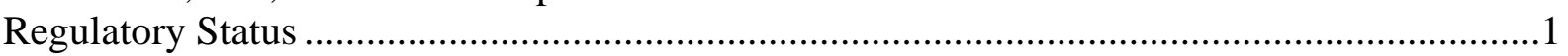

Absorption, Distribution, Metabolism, and Excretion ...........................................................

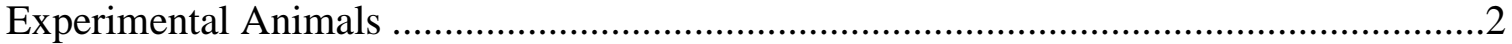

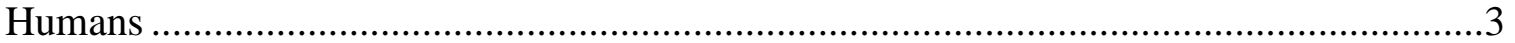

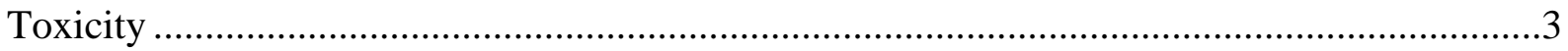

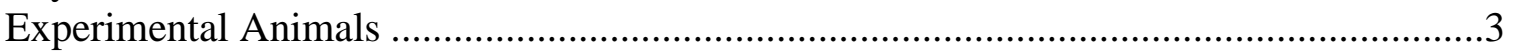

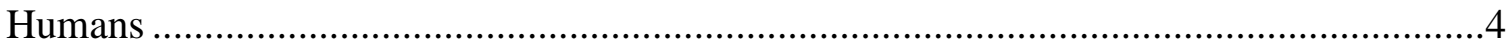

Reproductive and Developmental Toxicity ......................................................................

Experimental Animals ..........................................................................................

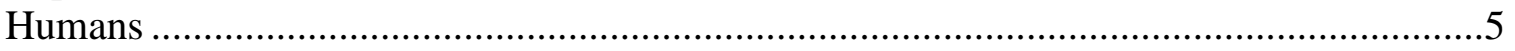

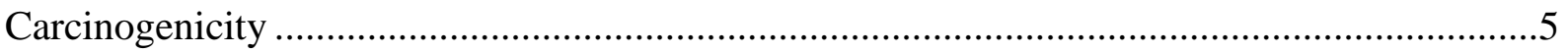

Experimental Animals ..........................................................................................

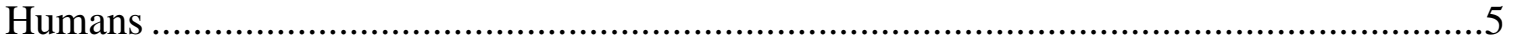

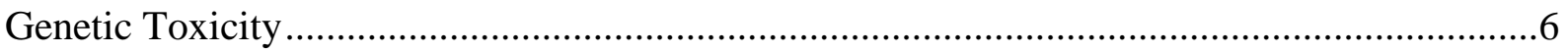

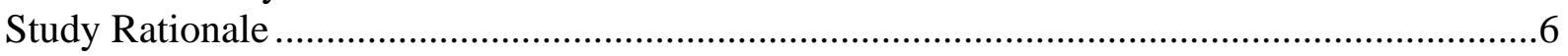

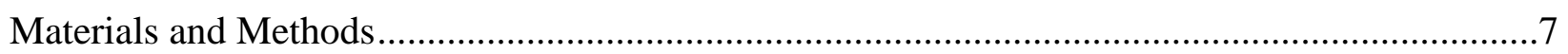

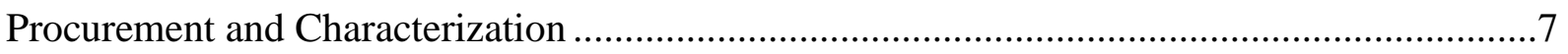

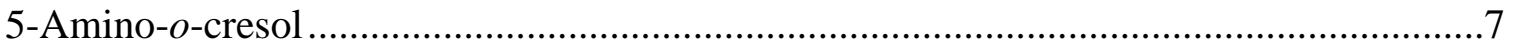

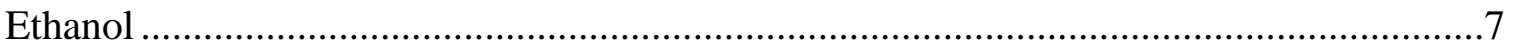

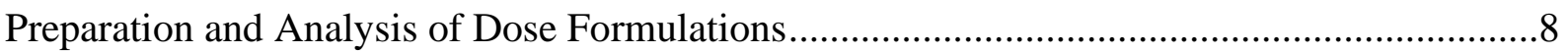

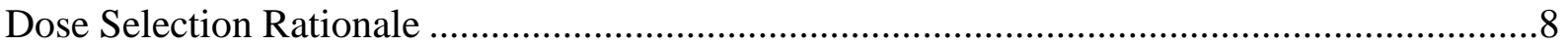

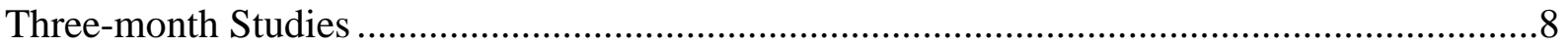

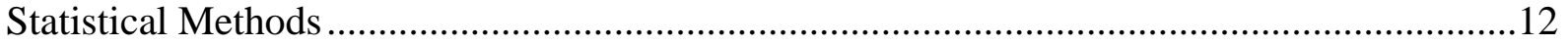

Calculation and Analysis of Lesion Incidences ...........................................................12

Analysis of Continuous Variables ............................................................................12

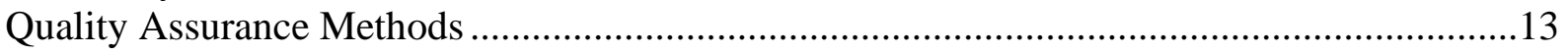

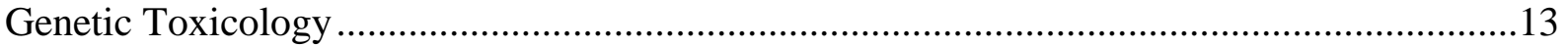

Salmonella typhimurium Mutagenicity Test Protocol .......................................................13

Mouse Peripheral Blood and Bone Marrow Micronucleus Test Protocols ........................13

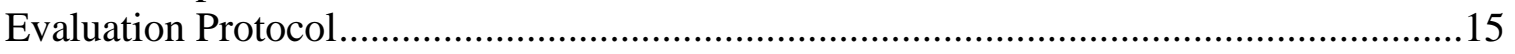




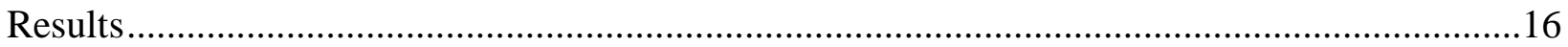

Three-month Study in Rats .....................................................................................16

Three-month Study in Mice ……………….............................................................19

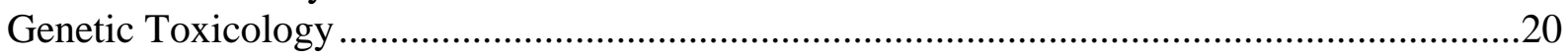

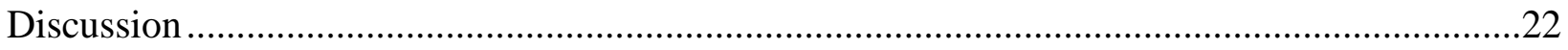

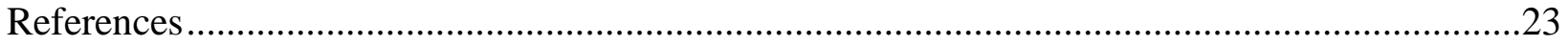

Appendix A. Summary of Lesions in Rats and Mice …………............................................ A-1

Appendix B. Clinical Pathology Results …………………................................................

Appendix C. Organ Weights and Organ-Weight-to-Body-Weight Ratios ......................................

Appendix D. Reproductive Tissue Evaluations and Estrous Cycle Characterization ................ D-1

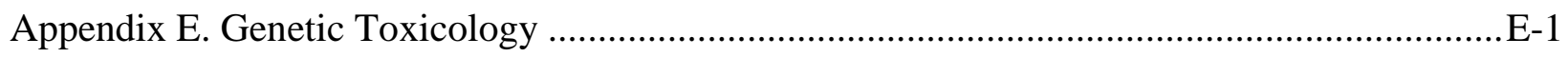

Appendix F. Chemical Characterization and Dose Formulation Studies .....................................F-1

Appendix G. Ingredients, Nutrient Composition, and Contaminant Levels in NTP-2000 Rat and Mouse Ration .................................................................................

Appendix H. Sentinel Animal Program .......................................................................... H-1

\section{Tables}

Table 1. Experimental Design and Materials and Methods in the Studies of 5-Amino-ocresol.....

Table 2. Survival and Body Weights of Rats in the Three-month Dermal Study of 5-Amino-o-cresol

Table 3. Survival and Body Weights of Mice in the Three-month Dermal Study of 5-Amino-o-cresol

\section{Figures}

Figure 1. 5-Amino-o-cresol (CASRN 2835-95-2; Chemical Formula: $\mathrm{C}_{7} \mathrm{H}_{9} \mathrm{NO}$;

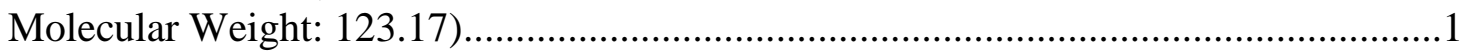

Figure 2. Urinary Metabolites of 5-Amino- $\mathrm{o}$-cresol in Rats.......................................................... 3

Figure 3. Growth Curves for Rats Administered 5-Amino-o-cresol Dermally for Three Months.....................................................................................................

Figure 4. Growth Curves for Mice Administered 5-Amino-o-cresol Dermally for Three Months

This report has been reformatted to meet new NTP publishing requirements; its content has not changed. 


\section{About This Report}

National Toxicology Program ${ }^{1}$

${ }^{1}$ Division of the National Toxicology Program, National Institute of Environmental Health Sciences, Research Triangle Park, North Carolina, USA

\section{Collaborators}

J.K. Dunnick, A.E. Brix, B. Atkinson, C.R. Blystone, C.A. Colleton, P.M. Foster, M.R. Hejtmancik, M.J. Hooth, A.P. King-Herbert, G.E. Kissling, D.E. Malarkey, B.S. McIntyre, B.J.T. Muir, S. Newbigging, T.A. Peace, J.C. Peckham, J.M. Sanders, M.D. Stout, G.S. Travlos, M.K. Vallant, S. Waidyanatha, N.J. Walker, Y. Wang, K.L. Witt

Division of the National Toxicology Program, National Institute of Environmental Health Sciences, Research Triangle Park, North Carolina, USA

Evaluated and interpreted results and reported findings

J.K. Dunnick, Ph.D., Study Scientist

C.R. Blystone, Ph.D.

P.M. Foster, Ph.D.

M.J. Hooth, Ph.D.

A.P. King-Herbert, D.V.M.

G.E. Kissling, Ph.D.

D.E. Malarkey, D.V.M., Ph.D.

B.S. McIntyre, Ph.D.

J.M. Sanders, Ph.D.

M.D. Stout, Ph.D.

G.S. Travlos, D.V.M.

M.K. Vallant, M.S., MT

S. Waidyanatha, Ph.D.

N.J. Walker, Ph.D.

K.L. Witt, M.S.

Battelle Columbus Operations, Columbus, Ohio, USA

Conducted studies and evaluated pathology findings

M.R. Hejtmancik, Ph.D., Principal Investigator

C.A. Colleton, D.V.M.

T.A. Peace, D.V.M.

Experimental Pathology Laboratories, Inc., Research Triangle Park, North Carolina, USA

Evaluated and interpreted results and reported findings

A.E. Brix, D.V.M., Ph.D., Study Pathologist

Conducted pathology review

J.C. Peckham, D.V.M., Ph.D. 
ILS, Inc., Research Triangle Park, North Carolina, USA

Coordinated NTP Pathology Working Group (February 14, 2008)

S. Newbigging, D.V.M., D.V.Sc.

Bridge Global Pharmaceutical Services, Inc., Gaithersburg, Maryland, USA

Provided SMVCE analysis

B.J.T. Muir, Ph.D., Principal Investigator

B. Atkinson, M.Sc.

Y. Wang, M.S.

\section{Contributors}

NTP Pathology Working Group, National Institute of Environmental Health Sciences, Research Triangle Park, North Carolina, USA

Participated in NTP Pathology Working Group (February 14, 2008)

S.A. Elmore, D.V.M. National Toxicology Program

J.C. Peckham, D.V.M, Ph.D., Experimental Pathology Laboratories, Inc.

Experimental Pathology Laboratories, Inc., Research Triangle Park, North Carolina, USA

Supervised pathology review

M.H. Hamlin, II, D.V.M., Principal Investigator

Dynamac Corporation, Research Triangle Park, North Carolina, USA

Prepared quality assessment audits

S. Brecher, Ph.D., Principal Investigator

S. Iyer, B.S.

V.S. Tharakan, D.V.M.

SRA International, Inc., Research Triangle Park, North Carolina, USA

Provided statistical analyses

R.W. Morris, Ph.D., Principal Investigator

L.J. Betz, M.S.

S.F. Harris, B.S.

Biotechnical Services, Inc., Little Rock, Arkansas, USA

Prepared Toxicity Study Report

S.R. Gunnels, M.A., Principal Investigator

L.M. Harper, B.S.

J.I. Irving, M.A.P.

T.S. Kumpe, M.A.

D.C. Serbus, Ph.D. 


\section{Peer Review}

The draft NTP Technical Report on the Toxicity Studies of 5-Amino-o-cresol (CASRN 2835-95-2) Administered Dermally to F344/NTac Rats and B6C3F1/N Mice was evaluated by the reviewers listed below. These reviewers served as independent scientists, not as representatives of any institution, company, or governmental agency. In this capacity, reviewers determined if the design and conditions of these NTP studies were appropriate and ensured that this NTP Toxicity Study Report presented the experimental results and conclusions fully and clearly.

\section{Peer Reviewers}

Donna F. Kusewitt, D.V.M., Ph.D.

University of Texas

Smithville, Texas, USA

Lena A. Nylander-French, Ph.D.

University of North Carolina at Chapel Hill

Chapel Hill, North Carolina, USA 


\section{Publication Details}

Publisher: National Toxicology Program

Publishing Location: Research Triangle Park, NC

ISSN: 2378-8992

DOI: https://doi.org/10.22427/NTP-TOX-89

Report Series: NTP Toxicity Report Series

Report Series Number: 89

Official citation: National Toxicology Program (NTP). 2015. NTP technical report on the toxicity studies of 5-amino-o-cresol (CASRN 2835-95-2) administered dermally to F344/NTac rats and B6C3F1/N mice. Research Triangle Park, NC: National Toxicology Program. Toxicity Report 89. 


\section{Abstract}

5-Amino-o-cresol is used as an oxidative dye coupler (secondary intermediate) or oxidative (permanent) in hair dye formulations. It was nominated for study by the National Cancer Institute because it is a widely used genotoxic hair dye component for which no cancer studies have been reported. Male and female F344/NTac rats and B6C3F1/N mice were administered 5amino-o-cresol (greater than $99 \%$ pure) dermally for 3 months. Genetic toxicology studies were conducted in Salmonella typhimurium, peripheral blood erythrocytes of male and female mice, and bone marrow of male mice.

Groups of 10 male and 10 female core study rats were dermally administered $0,2,4,8$, 16, or $32 \mathrm{mg} 5$-amino- $O$-cresol/kg body weight in 95\% ethanol, 5 days per week for 14 weeks; additional groups of 10 male and 10 female clinical pathology study rats were administered the same doses for 23 days. Groups of 10 male and 10 female mice were administered 0, 8, 16, 32, 64 , or $128 \mathrm{mg} / \mathrm{kg}$ for 14 weeks.

All rats survived to the end of the study. Mean body weights of all dosed groups of rats were similar to those of the vehicle control groups. There were no biologically significant differences between dosed and vehicle control groups in hematology or clinical chemistry parameters or in organ weights. Administration of 8,16 , or $32 \mathrm{mg} / \mathrm{kg}$ did not result in significant changes/differences in reproductive organ histopathology, sperm parameters of male rats, or the estrous cyclicity of female rats when compared to the vehicle controls. There were no gross or microscopic lesions that were considered biologically relevant or treatment related.

All male mice survived to the end of the study; one $32 \mathrm{mg} / \mathrm{kg}$ female mouse died spontaneously on day 73. Mean body weights of all dosed groups of mice were similar to those of the vehicle control groups. There were no statistically significant differences between dosed and vehicle control groups in hematology parameters or in organ weights. Administration of 32, 64, or $128 \mathrm{mg} / \mathrm{kg}$ did not result in significant changes/differences in reproductive organ histopathology, sperm parameters of male mice, or the estrous cyclicity of female mice when compared to the vehicle controls. There were no gross or microscopic lesions that were considered treatment related.

5-Amino-o-cresol was tested for mutagenicity in four strains of S. typhimurium (TA97, TA98, TA100, and TA1535) with and without $10 \%$ induced rat or hamster liver S9 enzymes; it was strongly positive in TA97, TA98, and TA100 in the presence of either species of S9. No mutagenicity was observed for 5-amino- $O$-cresol in strain TA1535, with or without S9. The strongest mutagenic response (based on fold-increase and the lowest effective dose) was seen in strain TA98, which mutates via frame shifting. In vivo, no increases in micronucleated erythrocytes were observed in peripheral blood of male or female B6C3F1/N mice in the current study. Likewise, no significant dose-related increases in the frequencies of micronucleated reticulocytes were seen in peripheral blood or bone marrow of male $\mathrm{B} 6 \mathrm{C} 3 \mathrm{~F} 1 / \mathrm{N}$ mice administered 50 to $400 \mathrm{mg} / \mathrm{kg} 5$-amino- $O$-cresol by gavage once daily for 3 days. No significant changes were seen in the percentage of reticulocytes in any of the micronucleus studies, suggesting that 5-amino- $O$-cresol did not induce bone marrow toxicity.

Synonyms: 4-Amino-2-hydroxy-1-methylbenzene; 4-amino-2-hydroxytoluene; 3-amino-6methylphenol; 5-amino-2-methylphenol; 2-hydroxy-4-aminotoluene; 3-hydroxy-4-methylaniline; 2-hydroxy-p-toluidine; 2-methyl-5-aminophenol; 6-methyl-3-aminophenol 


\section{Introduction}

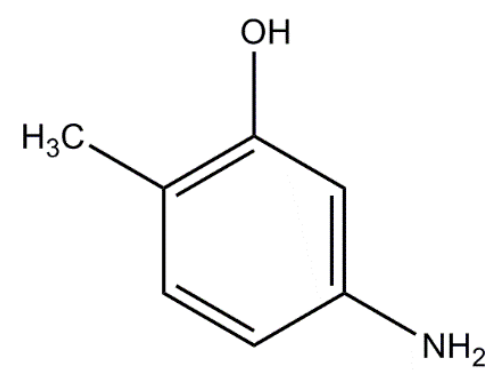

Figure 1. 5-Amino-o-cresol (CASRN 2835-95-2; Chemical Formula: $\mathrm{C}_{7} \mathrm{H}_{9} \mathrm{NO}$; Molecular Weight: 123.17)

Synonyms: 4-Amino-2-hydroxy-1-methylbenzene; 4-amino-2-hydroxytoluene; 3-amino-6-methylphenol; 5-amino-2-methylphenol; 2-hydroxy-4-aminotoluene; 3-hydroxy-4-methylaniline; 2-hydroxy-p-toluidine; 2-methyl-5-aminophenol; 6-methyl-3-aminophenol.

\section{Chemical and Physical Properties}

5-Amino- $O$-cresol is a beige powder with solubility in water of $2,427 \mathrm{mg} / \mathrm{L}$, and it reacts with oxidizing agents ${ }^{1}$. It has a melting point of $160^{\circ} \mathrm{C}$ and a $\log$ octanol:water partition coefficient of $0.79^{2 ; 3}$.

\section{Production, Use, and Human Exposure}

5-Amino- $o$-cresol is the most widely used member of a class of 25 chemicals, the aminocresols and related compounds, defined as amino- and methyl-substituted phenols, their salts, and ethers. 5-Amino-o-cresol (4-amino-2-hydroxytoluene) is used as an oxidative dye coupler (secondary intermediate) or oxidative (permanent) in hair dye formulations ${ }^{4 ; 5}$. Use of the aminophenols as hair dyes (including 5-amino-o-cresol) began in the 19 th century ${ }^{6}$. In 2006, 5-amino-o-cresol was used in 628 hair dye and color products, in 12 tint products, and one lightener product; the average concentration for this hair dye product ranged from $0.2 \%$ to $2 \% 5$.

The number of barbers, hairdressers, and cosmetologists employed in the United States in 2010 was estimated to be 712,200 by the Bureau of Labor Statistics (BLS) ${ }^{7}$. This group may be exposed to 5-amino- $O$-cresol as a component in hair dyes. It is estimated that more than one third of women over age 18 and about 10 percent of men over age 40 use some type of hair dye ${ }^{8 ; 9}$. The National Occupational Exposure Survey, between 1981 and 1983, estimated that 44,842 employees were potentially exposed to 5 -amino-o-cresol in the workplace ${ }^{10}$.

The estimated worldwide use of 5-amino-o-cresol is 150 to 250 tons per year (data provided by the international hair-dye industry and covers approximately $90 \%$ of the world market ${ }^{11}$ ).

\section{Regulatory Status}

Hair dyes and hair dye ingredients are regulated as cosmetic products by the Food and Drug Administration (FDA) ${ }^{12}$. Cosmetics produced or distributed for retail sale to consumers for their personal care are required to list ingredients. Hair preparations used by professionals at their establishments and places of work are exempt from this requirement provided that these products are not sold to consumers for home use. 
The FDA restricts the use of certain color additives under the Federal Food, Drug, and Cosmetic (FD\&C) Act. These restrictions are contained in the Code of Federal Regulations ${ }^{13-15}$. Under the FD\&C Act, the FDA does not have authority to require premarket approval for cosmetics, but it can take action when safety issues surface ${ }^{12 ; 16}$.

Various United States patents have been issued for 5-amino- $o$-cresol ${ }^{4}$. 5-Amino- $O$-cresol is used in the production of neutral red color shades ${ }^{17}$.

\section{Absorption, Distribution, Metabolism, and Excretion}

\section{Experimental Animals}

NTP conducted absorption, distribution, metabolism, and excretion studies of 5-amino- $O$-cresol in female F344/N rats and female B6C3F1 mice following single gavage administration, intravenous administration, or dermal application ${ }^{18}$. Absorption of 5-amino- $O$-cresol was complete following gavage administration in rats (4 to $357 \mathrm{mg} / \mathrm{kg})$ and mice $(36 \mathrm{mg} / \mathrm{kg})$. Excretion was mainly in the urine, and more than $80 \%$ of the administered dose was excreted in the urine within 24 hours. Absorption of 5-amino-o-cresol in rats 24 or 72 hours following dermal application (protected from oral grooming) was less than $10 \%$ of the applied dose (2.5 or $26 \mathrm{mg} / \mathrm{kg}$; the application site was rinsed 6 hours after application). When the dermal site was unprotected from grooming, $36 \%$ to $66 \%$ of the applied dose $(2.5$ to $32 \mathrm{mg} / \mathrm{kg}$ ) was absorbed within 24 or 72 hours indicating that the oral exposure through grooming contributes significantly to the total absorbed dose. As observed following oral or intravenous administration, the majority of the absorbed dose was excreted in the urine. The radioactivity in tissues was low ( $0.2 \%$ to $3.6 \%$ of the dose), regardless of the dose, route, or species. Disposition of 5-amino- $O$-cresol in female Wistar Han rats following intravenous $(12.5 \mathrm{mg} / \mathrm{kg})$ or gavage $\left(12.5\right.$ or $500 \mathrm{mg} / \mathrm{kg}$ ) administration was similar to that reported by Hedtke et al. ${ }^{18}$ with $94 \%$ or $78 \%$ or greater, respectively, of the administered dose excreted in urine within 24 hours ${ }^{19}$. The absorption following dermal application of 12.5 or $37.5 \mathrm{mg} / \mathrm{kg}$ in female Wistar Han rats (dose site occluded and oral grooming prevented) was $59 \%$ or $35 \%$, respectively, and was similar to the values reported by Hedtke et al. ${ }^{18}$ when the dose site was unprotected.

In F344 rats, following gavage administration of 5-amino-o-cresol, five metabolites were identified in urine (Figure 2$)^{18}$. The major metabolism was by sulfation or glucuronidation of the hydroxyl group. Following intravenous administration, M5 was the predominant metabolite; whereas following gavage administration, more or less equal amounts of M1 through M5 were observed. These results imply that the first-pass hepatic metabolism might be responsible for metabolism of 5-amino- $o$-cresol to M1, M2, and M4. Goebel et al. ${ }^{19}$ reported three major metabolites, M2, M3, and $\mathrm{N}$-acetylated 5-amino-o-cresol or its sulfate conjugate, M5, following all three routes of administration. However, at the same dose given, $\mathrm{N}$-acetylated 5 -amino- $O$-cresol constituted $66 \%$ of the dose following dermal application compared to $32 \%$ or $37 \%$ following gavage or intravenous administration, respectively. These data imply that following dermal application, $N$-acetylation of 5-amino- $O$-cresol represents a first-pass metabolism prior to entering the systemic circulation. 


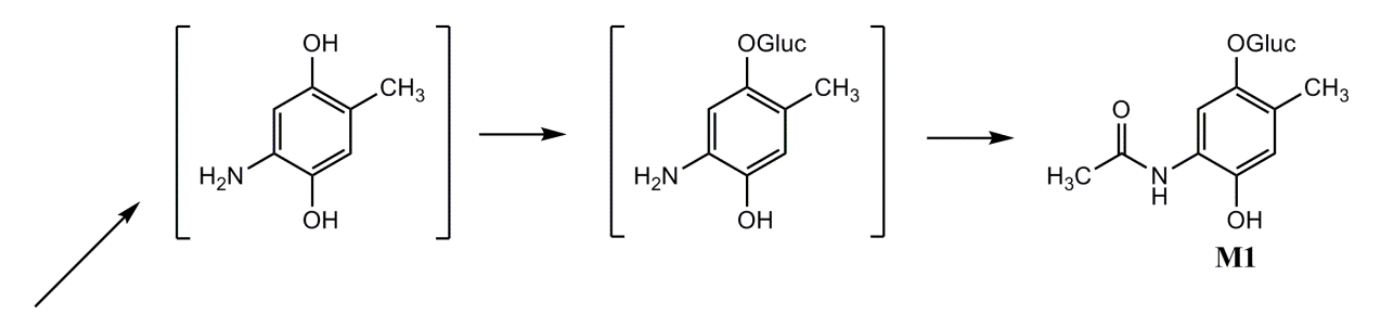<smiles>CCOc1cc(NC(C)=O)ccc1C</smiles><smiles>CC(=O)Nc1ccc(C)c(OS(=O)(=O)O)c1</smiles>

Figure 2. Urinary Metabolites of 5-Amino-o-cresol in Rats

\section{Humans}

Percutaneous absorption of 5-amino- $O$-cresol in a hair dye under the conditions of usage was studied by Wolfram and Maibach ${ }^{20}$. Radiolabeled 5-amino- $O$-cresol was added to a commercial dye containing $0.69 \%$ nonradioactive 5-amino- $O$-cresol; the mixture was applied to the dry hair of three volunteers, worked into the hair mass for 5 to 8 minutes, and rinsed out after an additional 20 minutes. Urine samples were collected for as long as radioactivity was detected, for approximately 144 hours. The total urinary excretion of radioactivity was $0.2 \%$ with $50 \%$ of that excreted in 24 hours. $N$-acetylated 5-amino- $O$-cresol was detected in human keratinocytes in vitro $^{21}$. In another study, 5-amino- $o$-cresol metabolism was compared in the human keratinocyte cell line $\mathrm{HaCaT}$ and in human skin in vitro ${ }^{19}$. $\mathrm{N}$-acetylated 5-amino- $O$-cresol was the only metabolite detected in $\mathrm{HaCaT}$ cells and human skin in vitro. Ogiso et al. ${ }^{22}$ reported penetration of 5 -amino-o-cresol through the scalp skin is generally greater than penetration through abdominal skin.

Taken together, these studies show that 5-amino-o-cresol passes through skin in small but detectable amounts.

\section{Toxicity}

\section{Experimental Animals}

The Hazardous Substances Data Bank ${ }^{1}$ summarizes the results of several 5-amino-o-cresol studies previously published elsewhere. The acute 5-amino- $O$-cresol oral LD50 values are $3,600 \mathrm{mg} / \mathrm{kg}$ for CFY rats and 2,928 and 4,355 mg/kg for female and male Sprague-Dawley rats, respectively. A dermal dose of up to $5 \mathrm{~g} / \mathrm{kg}$ produced no dermal toxicity in rabbits. 
Dietary administration of 5-amino- $o$-cresol in subchronic toxicity studies in Sprague Dawley rats was conducted at concentrations of $0 \%, 0.3 \%, 1 \%$, or $3 \%$ for periods of 3 to 6 months ${ }^{1}$.

Significant reductions in body weights occurred in male and female rats fed $3 \%$ and in males fed $1 \%$. No significant differences in the concentrations of methemoglobin or triiodothyronine were noted between the high-dose and control rats; however, the total thyroxine and the free thyroxine serum levels were decreased in the high-dose rats. Thyroid glands of the high- and mid-dose rats showed moderate follicular cell hyperplasia and misshapen and small follicles. Exposure to 5-amino-o-cresol produced significant hepatotoxic effects manifested by centrilobular hepatocytomegaly in an unspecified number of test rats and one control female. Mid- and highdose male rats exhibited a significant dose-dependent increase in serum glutamic pyruvic transaminase activity. Significant dose-dependent decreases in erythrocyte counts, hemoglobin concentrations, and hematocrit values and increases in mean cell volumes occurred in exposed rats. These observations were suggestive of anemia and may have been related to nutritional deficiency.

Sensitization was evaluated in albino guinea pigs receiving a 3\% dermal dose applied daily for 3 weeks, 6 days per week [a mixture of Natrosol ${ }^{\circledR} 250 \mathrm{HR}(2.0 \%)$, Tween 80 (2.0\%), sodium sulfite $(0.05 \%)$, deionized water $(82.95 \%)$, and isopropanol $(10.0 \%)$ was used as the vehicle $]^{1}$. Two weeks after the last dose of 5-amino-o-cresol, a challenge application was made on the opposite untreated flank of each animal. Reactions were scored on a scale of 0 to 4 . Four of the 19 guinea pigs had a reaction, with the total point score (for all four animals) of 4 . It was concluded that very weak sensitization was produced by 5 -amino- $O$-cresol. Other studies describe 5-amino- $O$-cresol as nonirritating to the skin and mildly irritating to the eye, based on tests in rabbits ${ }^{23}$.

Immunotoxicity tests of 5-amino-o-cresol in the local lymph node assay in $\mathrm{Balb} / \mathrm{C}$ mice demonstrated increased proliferation of the draining lymph node cells at concentrations of $5 \%$ and $10 \%$ applied dermally (4:1 acetone:olive oil vehicle) indicating contact hypersensitization activity of 5-amino- $O$-cresol ${ }^{24}$. However, 5-amino- $O$-cresol did not appear to be an irritant as measured in a dermal irritancy assay. Furthermore, 5 -amino- $o$-cresol did not have significant effects on the percent of mouse ear swelling in a mouse ear swelling test.

\section{Humans}

No epidemiology studies examining the toxicity of 5-amino- $O$-cresol as a single chemical component in hair dyes have been reported in the literature.

In a modified Draize repeat-insult patch test, two aqueous 2\% 5-amino-o-cresol solutions (3\% $\mathrm{v} / \mathrm{v}$ and $10 \% \mathrm{w} / \mathrm{v}$ ) were administered to volunteers ${ }^{1}$. A dose-related increase in dermatitis was observed ( 1 of 23, not reproduced, versus 2 of 31,1 reproduced on rechallenge).

\section{Reproductive and Developmental Toxicity}

\section{Experimental Animals}

Groups of 25 female Sprague Dawley rats were fed diets containing 0\%, 0.3\%, 1\%, or 3\% 5 -amino- $o$-cresol for 14 weeks, then mated with untreated males ${ }^{1}$. Feeding was resumed at the same exposure concentrations for the duration of gestation. While no visceral malformations were noted, there were significant increases in the number of rudimentary 14 th ribs in the mid- 
and high-dose animals and a slight increase in the number of full 14th ribs in the fetuses of these dose groups.

In a dominant lethal study of 5-amino-o-cresol, 20 male rats from each dose group were removed from the test diet $(0 \%, 0.3 \%, 1 \%, 3 \%)$ after 20 weeks and mated to two untreated females each week for 2 weeks ${ }^{1}$. All males, except one in the mid-dose group, sired at least one litter. No significant dose-related differences were noted in any of the male reproductive parameters studied. The authors concluded that 5-amino- $o$-cresol produced no adverse effects on reproductive performance and no dominant lethal effect.

\section{Humans}

There are no studies reported in the literature on the reproductive or developmental toxicity of 5 -amino- $o$-cresol in humans.

\section{Carcinogenicity}

\section{Experimental Animals}

There are no studies reported in the literature on carcinogenic effects of 5-amino- $o$-cresol in experimental animals.

\section{Humans}

There are no epidemiology studies examining the potential carcinogenic effects of 5 -amino- $o$-cresol reported in the literature. The National Cancer Institute $(\mathrm{NCI})^{8}$ has summarized information on the association of hair dye use in general with cancer and points out that there are conflicting results for such studies.

A 2009 review of 247 studies reporting relative risk of hairdresser occupation and cancer at different sites found that there was a higher risk of cancer in this occupation than in the general population $^{25}$.

Hair dye use has been evaluated in a number of cohort studies for its possible association with cancer. The International Agency for Research on Cancer (IARC) ${ }^{26}$ evaluated six European studies of male hairdressers and barbers; some studies showed an increased risk for urinary bladder tumors. IARC concluded that occupation as a hairdresser or barber entails exposures that are probably carcinogenic. However, linkage between personal use of hair dyes and cancer could not be evaluated. Other studies, which investigated association between permanent hair dye use and breast and hematopoietic cancers, yielded largely negative results ${ }^{27}$.

Case control studies conducted in California ${ }^{28 ; 29}$ showed some linkage between permanent hair dye use and bladder cancer in American women. Other population-based studies looked at an association between hair dye use and cancer in women in Nebraska or Connecticut ${ }^{30-33}$. In these population-based studies of 112 women who were diagnosed with glioma, a 1.7-fold increased risk of glioma was observed in women who had used any hair coloring product ( $95 \%$ confidence interval $(\mathrm{CI})=1.0$ to $2.9,62$ cases) and a 2.4-fold risk in those who used permanent hair coloring products (odds ratio $(\mathrm{OR})=2.4,95 \% \mathrm{CI}=1.3$ to $4.5,39$ cases $)^{30}$. No association was observed with use of nonpermanent (sometimes called temporary or semipermanent) hair coloring products $^{30}$. 
A study in Connecticut examined the association between hair dye use and non-Hodgkin's lymphoma ${ }^{33}$. A total of 601 histologically confirmed female cases and 717 population-based controls were included in the study. An increased risk of non-Hodgkin's lymphoma was observed among women who reported use of hair-coloring products before 1980 (OR = 1.3, 95\% CI: 1.0 to 1.8$)$. The odds ratios were 2.1 (95\% CI: 1.0 to 4.0$)$ for those using darker permanent hair-coloring products for more than 25 years and 1.7 (95\% CI: 1.0 to 2.8) for those who had more than 200 applications. Follicular-type, B-cell, and low-grade lymphoma generally showed an increased risk. On the other hand, the authors found no increased risk of non-Hodgkin's lymphoma overall and by subtype of exposure and disease among women who started using haircoloring products in 1980 or later.

A population-based, case control study of 385 non-Hodgkin's lymphoma cases, 70 Hodgkin's disease cases, 72 multiple myeloma cases, 56 chronic lymphocytic leukemia cases, and 1,432 controls found that hair coloring product use appeared to increase the risk of non-Hodgkin's lymphoma ${ }^{32}$. The same study found that the risks were higher among women who used brown, black, or red hair dyes, i.e., colors whose preparation may involve 5 -amino- $o$-cresol ${ }^{13}$. None of the epidemiological studies found in the literature discussed the specific ingredients (5-amino-o-cresol) contained in the hair dyes.

\section{Genetic Toxicity}

5-Amino-o-cresol was tested for mutagenicity over a dose range of 33 to $6,666 \mu \mathrm{g} / \mathrm{plate}$ in four strains of Salmonella typhimurium (TA97, TA98, TA100, and TA1535) with and without $10 \%$ induced male Sprague-Dawley rat or Syrian hamster liver S9 enzymes; it was positive in three of four strains (TA97, TA98, and TA100) in the presence of either species of S9 and negative in TA1535 with or without $S 9^{34}$. Among the three strains that gave positive responses, the strongest mutagenic response (based both on fold-increase and the lowest effective dose) occurred in TA98, a strain that reverts via frame shifting.

In short-term tests for assessment of micronucleated reticulocyte frequencies in blood or bone marrow of male B6C3F1/N mice administered 5-amino- $o$-cresol (100 to $400 \mathrm{mg} / \mathrm{kg}$ per day) via gavage once daily for 3 days, no significant increases were observed ${ }^{35}$. In addition, no significant changes in the percentage of reticulocytes were seen in these mice, suggesting that 5 -amino- $O$-cresol did not induce bone marrow toxicity over the dose range tested.

\section{Study Rationale}

5-Amino-o-cresol was nominated for study by the NCI because it is a widely used genotoxic hair dye component for which no cancer studies have been reported. These 5-amino-o-cresol studies were conducted by the dermal route to mimic human exposure, and to identify any target organ toxicity by this route of administration. 


\section{Materials and Methods}

\section{Procurement and Characterization}

\section{5-Amino-o-cresol}

5-Amino-o-cresol was obtained from Fluka Chemical Company (Buchs, Switzerland) in one lot $(385913 / 1)$ that was used in the 3-month dermal studies. Identity, purity, and stability analyses were conducted by the analytical chemistry laboratory at Research Triangle Institute (Research Triangle Park, NC) and the study laboratory at Battelle Columbus Operations (Columbus, $\mathrm{OH}$ ) (Appendix F). Karl Fischer titration was performed by Galbraith Laboratories (Knoxville, TN). Reports on analyses performed in support of the 5-amino-o-cresol studies are on file at the National Institute of Environmental Health Sciences.

The chemical, a beige powder, was identified as 5-amino-o-cresol using infrared spectroscopy, nuclear magnetic resonance spectroscopy, gas chromatography (GC) with mass spectrometry, and melting point determination. Karl Fischer titration was used to determine the water content of the test chemical. The purity of lot 385913/1 was determined using GC with flame ionization detection (FID) and high-performance liquid chromatography (HPLC) with ultraviolet light (UV) detection.

Karl Fischer titration indicated a range of $0.14 \%$ to $0.48 \%$ water. GC/FID analysis by one system indicated one major peak with three impurities greater than $0.1 \%$ of the total peak area, with a combined total of $0.80 \%$ of the total peak area. GC/FID analysis by a second system indicated one major peak and one impurity with an area of $0.37 \%$ relative to the total peak area. HPLC/UV indicated one major peak and no impurities. The overall purity of lot 385913/1 was estimated to be greater than $99 \%$.

Stability studies of the bulk chemical were performed using GC/FID. These studies indicated that 5-amino- $O$-cresol was stable as a bulk chemical for at least 2 weeks when stored protected from light at temperatures up to $25^{\circ} \mathrm{C}$. To ensure stability, the test chemical was stored in sealed amber glass vials at room temperature $\left(\sim 25^{\circ} \mathrm{C}\right)$. Periodic reanalyses of the test chemical were performed using HPLC/UV and no degradation was observed.

\section{Ethanol}

USP-grade 95\% ethanol was obtained from Spectrum Chemicals and Laboratory Products (Gardena, CA) in one lot (UO0008) that was used as the vehicle in the 3-month dermal studies. Identity, purity, and trace benzene analyses were conducted by the study laboratory.

The chemical, a clear liquid, was confirmed as ethanol using infrared spectroscopy. Purity of the bulk chemical was determined using GC/FID; no impurities greater than $0.1 \%$ of the total peak area were detected by one system, and no benzene was detected by a second system. The overall purity of lot UO0008 was determined to be greater than $99 \%$.

The bulk chemical was stored normally at ambient conditions. Reanalyses using GC/FID detected no degradation of the vehicle. 


\section{Preparation and Analysis of Dose Formulations}

The dose formulations were prepared four times by mixing 5 -amino-o-cresol with $95 \%$ ethanol to give the required concentrations. Stability studies of the $4 \mathrm{mg} / \mathrm{mL}$ dose formulation were performed by the analytical chemistry laboratory using HPLC/UV. Stability was confirmed for at least 42 days for dose formulations stored in glass containers sealed with Teflon ${ }^{\circledR}$-lined lids, protected from light, at temperatures up to $25^{\circ} \mathrm{C}$, and for 3 hours under simulated animal room conditions.

Analyses of the dose formulations of 5-amino- $o$-cresol were conducted three times by the study laboratory using HPLC/UV; animal room samples of these dose formulations were also analyzed (Table F-4). All 15 dose formulations analyzed for rats and mice were within $10 \%$ of the target concentrations; all 15 animal room samples for rats and all 15 for mice were within $10 \%$ of the target concentrations.

\section{Dose Selection Rationale}

5-Amino- $O$-cresol was administered by the dermal route to mimic human exposure to the chemical from hair dye use. The solubility of 5-amino- $o$-cresol was limited to approximately $60 \mathrm{mg} / \mathrm{mL}$ in ethanol ${ }^{36}$. For the rat study, stock solutions of $0,4,8,16,32$, or $64 \mathrm{mg}$ 5 -amino- $O$-cresol $/ \mathrm{mL}$ were prepared in $95 \%$ ethanol and applied at $0.5 \mathrm{~mL} / \mathrm{kg}$ body weight to deliver $0,2,4,8,16$, or $32 \mathrm{mg} 5$-amino- $o$-cresol/kg body weight. For the mouse study, stock solutions of $0,4,8,16,32$, or $64 \mathrm{mg} / \mathrm{mL}$ were prepared in $95 \%$ ethanol and applied at $2.0 \mathrm{~mL} / \mathrm{kg}$ to deliver $0,8,16,32,64$, or $128 \mathrm{mg} / \mathrm{kg}$. The five doses included the maximum dose that could be administered by the dermal route.

\section{Three-month Studies}

Male and female F344/NTac rats and B6C3F1/N mice were obtained from Taconic Farms, Inc. (Germantown, NY). On receipt, the rats were 3 to 4 weeks old and the mice were 4 to 5 weeks old. Animals were quarantined for 11 or 12 days (rats) or 13 or 14 days (mice); rats were 5 to 6 weeks old and mice were 6 to 7 weeks old on the first day of the studies. Before the studies began, five male and five female rats and mice were randomly selected for parasite evaluation and gross observation for evidence of disease. Serologic analyses were performed on five male and five female sentinel rats and mice at 4 weeks and five male and four or five female rats and mice at the end of the studies using the protocols of the NTP Sentinel Animal Program (Appendix H). All test results were negative.

Groups of 10 male and 10 female core study rats were dermally administered $0,2,4,8$, 16, or $32 \mathrm{mg} / \mathrm{kg} 5$ days per week for 14 weeks; additional groups of 10 male and 10 female clinical pathology study rats were administered the same doses for 23 days. Groups of 10 male and 10 female mice were administered $0,8,16,32,64$, or $128 \mathrm{mg} / \mathrm{kg}$ for 14 weeks. Doses were administered in $95 \%$ ethanol at volumes of $0.5 \mathrm{~mL} / \mathrm{kg}$ (rats) or $2 \mathrm{~mL} / \mathrm{kg}$ (mice); vehicle control animals received the $95 \%$ ethanol vehicle only. Doses were applied once daily to the dorsal skin application site, which was clipped weekly. Feed and water were available ad libitum. Animal care and use are in accordance with the public Health Service Policy on Humane Care and Use of Animals. All animal studies were conducted in an animal facility accredited by the Association for the Assessment and Accreditation of Laboratory Animal Care International. 
Studies were approved by the Battelle Columbus Operations Animal Care and Use Committee and conducted in accordance with all relevant NIH and NTP animal care and use policies and applicable federal, state, and local regulations and guidelines. Rats and mice were housed individually. All animals were weighed and clinical findings were recorded on day 1, weekly, and at the end of the studies. Details of the study design and animal maintenance are summarized in Table 1. Information on feed composition and contaminants is provided in Appendix G.

Animals were anesthetized with a carbon dioxide/oxygen mixture. Blood was collected from the retroorbital plexus of clinical pathology study rats on days 4 and 23 and core study rats at the end of the studies for hematology and clinical chemistry endpoints. Blood was collected from the retroorbital sinus of mice at the end of the studies for hematology endpoints. Blood samples for hematology were collected in tubes containing EDTA. Blood samples for clinical chemistry were placed in serum separator tubes. Hematology parameters were measured using an ADVIA ${ }^{\circledR} 120$ Hematology Analyzer (Bayer Diagnostics Division, Tarrytown, NY). Clinical chemistry parameters were determined using the Hitachi 911 chemical analyzer (Roche Diagnostics, Indianapolis, IN). The parameters measured are listed in Table 1.

At the end of the 3-month studies, samples were collected for sperm motility or vaginal cytology evaluations on male and female rats in the $0,8,16$, and $32 \mathrm{mg} / \mathrm{kg}$ groups and male and female mice in the $0,32,64$, and $128 \mathrm{mg} / \mathrm{kg}$ groups. The parameters evaluated are listed in Table 1 . For 16 consecutive days prior to scheduled terminal sacrifice, the vaginal vaults of the females were moistened with saline, if necessary, and samples of vaginal fluid and cells were stained. Relative numbers of leukocytes, nucleated epithelial cells, and large squamous epithelial cells were determined and used to ascertain estrous cycle stage (i.e., diestrus, proestrus, estrus, and metestrus). Male animals were evaluated for sperm count and motility. The left testis and left epididymis were isolated and weighed. The tail of the epididymis (cauda epididymis) was then removed from the epididymal body (corpus epididymis) and weighed. Test yolk (rats) or modified Tyrode's buffer (mice) was applied to slides and a small incision was made at the distal border of the cauda epididymis. The sperm effluxing from the incision were dispersed in the buffer on the slides, and the numbers of motile and nonmotile spermatozoa were counted for five fields per slide by two observers. Following completion of sperm motility estimates, each left cauda epididymis was placed in buffered saline solution. Caudae were finely minced, and the tissue was incubated in the saline solution and then heat fixed at $65^{\circ} \mathrm{C}$. Sperm density was then determined microscopically with the aid of a hemacytometer. To quantify spermatogenesis, the testicular spermatid head count was determined by removing the tunica albuginea and homogenizing the left testis in phosphate-buffered saline containing $10 \%$ dimethyl sulfoxide. Homogenization-resistant spermatid nuclei were counted with a hemacytometer.

Necropsies were performed on all core study rats and mice. The heart, right kidney, liver, lung, right testis, and thymus were weighed. Tissues for microscopic examination were fixed and preserved in $10 \%$ neutral buffered formalin (eyes were first fixed in Davidson's solution), processed and trimmed, embedded in paraffin, sectioned to a thickness of 4 to $6 \mu \mathrm{m}$, and stained with hematoxylin and eosin. Complete histopathologic examinations (organs listed in Table 1) were performed by the study laboratory pathologist on rats in the 0 and $32 \mathrm{mg} / \mathrm{kg}$ groups and mice in the 0 and $128 \mathrm{mg} / \mathrm{kg}$ groups. In addition, the kidneys and lungs of mice were examined from all dose groups, and the thyroid gland, liver, and lung were examined from all dose groups of rats. 
After a review of the laboratory reports and selected histopathology slides by a quality assessment (QA) pathologist, the findings and reviewed slides were submitted to a NTP Pathology Working Group (PWG) coordinator for a second independent review. Any inconsistencies in the diagnoses made by the study laboratory and QA pathologists were resolved by the NTP pathology peer review process. Final diagnoses for reviewed lesions represent a consensus of the PWG or a consensus between the study laboratory pathologist, NTP pathologist, QA pathologist(s) and the PWG coordinator. Details of these review procedures have been described, in part, by Maronpot and Boorman ${ }^{37}$ and Boorman et al. ${ }^{38}$.

Table 1. Experimental Design and Materials and Methods in the Studies of 5-Amino-o-cresol

\section{Three-month Dermal Studies}

Study Laboratory

Battelle Columbus Operations (Columbus, $\mathrm{OH}$ )

Strain and Species

F344/NTac rats

B6C3F1/N mice

Animal Source

Taconic Farms, Inc. (Germantown, NY)

Time Held Before Studies

Rats: 11 (males) or 12 (females) days

Mice: 13 (females) or 14 (males) days

Average Age When Studies Began

Rats: 5 to 6 weeks

Mice: 6 to 7 weeks

\section{Date of First Dose}

Rats: May 8 (males) or 9 (females), 2006

Mice: May 10 (females) or 11 (males), 2006

\section{Duration of Dosing}

5 days per week for 23 days (clinical pathology study rats) or 14 weeks (core study rats and mice)

\section{Date of Last Dose}

Rats (clinical pathology study): May 30 (males) or 31 (females), 2006

Rats (core study): August 7 (males) or 8 (females), 2006

Mice: August 9 (females) or 10 (males), 2006

\section{Necropsy Dates}

Rats (core study): August 8 (males) or 9 (females), 2006

Mice: August 10 (females) or 11 (males), 2006

\section{Average Age at Necropsy}

Rats: 18 to 19 weeks

Mice: 19 to 20 weeks

\section{Size of Study Groups}

10 males and 10 females 


\section{Three-month Dermal Studies}

\section{Method of Distribution}

Animals were distributed randomly into groups of approximately equal initial mean body weights.

\section{Animals per Cage}

1

\section{Method of Animal Identification}

Tail tattoo

\section{Diet}

Irradiated NTP-2000 open formula wafer feed (Zeigler Brothers, Inc., Gardners, PA), available ad libitum; changed at least weekly

\section{Water}

Tap water (City of Columbus municipal supply) via automatic watering system (Edstrom Industries, Waterford, WI), available ad libitum

\section{Cages}

Polycarbonate [Allentown Caging Equipment Company, Allentown, NJ (rats) or Lab Products, Inc., Seaford, DE (mice)], changed weekly

\section{Bedding}

Irradiated Sani Chips ${ }^{\circledR}$ (P.J. Murphy Forest Products Corp., Montville, NJ), changed weekly

\section{Rack Filters}

Spun-bonded polyester (Snow Filtration, Cincinnati, OH) changed every 2 weeks

\section{Racks}

Stainless steel (Lab Products, Inc., Seaford, DE), changed every 2 weeks

\section{Animal Room Environment}

Temperature: $72^{\circ} \pm 3^{\circ} \mathrm{F}$

Relative humidity: $50 \% \pm 15 \%$

Room fluorescent light: 12 hours/day

Room air changes: at least 10/hour

\section{Doses}

Rats: $0,2,4,8,16$, or $32 \mathrm{mg} / \mathrm{kg}$ in $95 \%$ ethanol (dosing volume, $0.5 \mathrm{~mL} / \mathrm{kg}$ )

Mice: $0,8,16,32,64$, or $128 \mathrm{mg} / \mathrm{kg}$ in $95 \%$ ethanol (dosing volume, $2 \mathrm{~mL} / \mathrm{kg}$ )

Type and Frequency of Observation

Observed twice daily; animals were weighed and clinical findings were recorded on day 1, weekly thereafter, and at the end of the studies.

\section{Method of Kill}

Carbon dioxide asphyxiation

\section{Necropsy}

Necropsies were performed on all core study rats and mice. Organs weighed were heart, right kidney, liver, lung, right testis, and thymus. 


\section{Three-month Dermal Studies}

\section{Clinical Pathology}

Blood was collected from the retroorbital sinus of clinical pathology study rats on days 4 and 23 and from core study animals at the end of the studies for hematology and clinical chemistry (rats only).

Hematology: hematocrit; hemoglobin; erythrocyte, reticulocyte, and platelet counts; mean cell volume; mean cell hemoglobin; mean cell hemoglobin concentration; and leukocyte count and differentials

Clinical Chemistry: urea nitrogen, creatinine, glucose, total protein, albumin, alanine aminotransferase, alkaline phosphatase, creatine kinase, sorbitol dehydrogenase, bile acids, and total thyroxine

\section{Histopathology}

Complete histopathology was performed on core study rats in the 0 and $32 \mathrm{mg} / \mathrm{kg}$ groups and mice in the 0 and $128 \mathrm{mg} / \mathrm{kg}$ groups. In addition to gross lesions and tissue masses, the following tissues were examined: adrenal gland, bone (femur) with marrow, brain, clitoral gland, esophagus, eye, gallbladder (mice), Harderian gland, heart and aorta, large intestine (cecum, colon, rectum), small intestine (duodenum, jejunum, ileum), kidney, liver, lung (with mainstem bronchus), lymph nodes (mandibular and mesenteric), mammary gland with adjacent (inguinal) skin, nose, ovary, pancreas, parathyroid gland, pituitary gland, preputial gland, prostate gland, salivary gland, seminal vesicle, skin (site of application), spleen, stomach (forestomach and glandular), testis (with epididymis), thymus, thyroid gland, trachea, urinary bladder, and uterus.

\section{Sperm Motility and Vaginal Cytology}

At the end of the studies, sperm samples were collected from male rats in the $0,8,16$, and $32 \mathrm{mg} / \mathrm{kg}$ groups and male mice in the $0,32,64$, and $128 \mathrm{mg} / \mathrm{kg}$ groups for sperm motility evaluations. The following parameters were evaluated: spermatid heads per gram testis and per testis, and epididymal spermatozoal motility and concentration. The left cauda, left epididymis, and left testis were weighed. Vaginal samples were collected for up to 16 consecutive days prior to the end of the studies from female rats in the $0,8,16$, and $32 \mathrm{mg} / \mathrm{kg}$ groups and female mice in the $0,32,64$, and $128 \mathrm{mg} / \mathrm{kg}$ groups for vaginal cytology evaluations.

\section{Statistical Methods}

\section{Calculation and Analysis of Lesion Incidences}

The incidences of lesions are presented in Appendix A as the numbers of animals bearing such lesions at a specific anatomic site and the numbers of animals with that site examined microscopically. The Fisher exact test ${ }^{39}$, a procedure based on the overall proportion of affected animals, was used to determine significance.

\section{Analysis of Continuous Variables}

Two approaches were employed to assess the significance of pairwise comparisons between dosed and vehicle control groups in the analysis of continuous variables. Organ and body weight data, which historically have approximately normal distributions, were analyzed with the parametric multiple comparison procedures of Dunnett ${ }^{40}$ and Williams ${ }^{41 ; 42}$. Hematology, clinical chemistry, spermatid, and epididymal spermatozoal data, which have typically skewed distributions, were analyzed using the nonparametric multiple comparison methods of Shirley ${ }^{43}$ (as modified by Williams ${ }^{44}$ ) Dunn ${ }^{45}$. Jonckheere's test ${ }^{46}$ was used to assess the significance of the dose-related trends and to determine whether a trend-sensitive test (Williams' or Shirley's test) was more appropriate for pairwise comparisons than a test that does not assume a monotonic dose-related trend (Dunnett's or Dunn's test). Prior to statistical analysis, extreme values identified by the outlier test of Dixon and Massey ${ }^{47}$ were examined by NTP personnel, and implausible values were eliminated from the analysis. Proportions of regular cycling females in each dosed group were compared to the vehicle control group using the Fisher exact test ${ }^{39}$. 
Tests for extended periods of estrus, diestrus, metestrus, and proestrus, as well as skipped estrus and skipped diestrus, were constructed based on a Markov chain model proposed by Girard and Sager $^{48}$. For each dose group, a transition probability matrix was estimated for transitions among the proestrus, estrus, metestrus, and diestrus stages, with provision for extended stays within each stage as well as for skipping estrus or diestrus within a cycle. Equality of transition matrices among dose groups and between the vehicle control group and each dosed group was tested using chi-square statistics.

\section{Quality Assurance Methods}

The 3-month studies were conducted in compliance with Food and Drug Administration Good Laboratory Practice Regulations ${ }^{49}$. The Quality Assurance Unit of Battelle Columbus Operations performed audits and inspections of protocols, procedures, data, and reports throughout the course of the studies.

\section{Genetic Toxicology}

\section{Salmonella typhimurium Mutagenicity Test Protocol}

Testing procedures used at BioReliance Corporation followed protocols reported by Zeiger et al. $^{34}$. 5-amino- $O$-cresol was sent to the laboratory as a coded sample. It was incubated with the Salmonella typhimurium tester strains TA97, TA98, TA100, and TA1535 either in buffer or S9 mix (metabolic activation enzymes and cofactors from Aroclor 1254-induced male Sprague Dawley rat or Syrian hamster liver) for 20 minutes at $37^{\circ} \mathrm{C}$. Top agar supplemented with L-histidine and d-biotin was added, and the contents of the tubes were mixed and poured onto the surfaces of minimal glucose agar plates. Histidine-independent mutant colonies arising on these plates were counted following incubation for 2 days at $37^{\circ} \mathrm{C}$.

Each trial consisted of triplicate plates of concurrent positive and negative controls and of five doses of 5-amino-o-cresol. The high dose was limited by toxicity. All trials that produced a positive response were repeated.

In this assay, a positive response is defined as a reproducible, dose-related increase in histidineindependent (revertant) colonies in any one strain/activation combination. An equivocal response is defined as an increase in revertants that is not dose related, is not reproducible, or is not of sufficient magnitude to support a determination of mutagenicity. A negative response is obtained when no increase in revertant colonies is observed following chemical treatment. There is no minimum percentage or fold increase required for a chemical to be judged positive or weakly positive although positive calls are typically reserved for increases in mutant colonies that are at least twofold over background.

\section{Mouse Peripheral Blood and Bone Marrow Micronucleus Test Protocols}

\section{Slide-Based Assay}

A detailed discussion of this assay is presented by MacGregor et al. ${ }^{50}$. At the termination of the 3-month dermal toxicity study, peripheral blood samples were obtained from male and female mice. Smears were immediately prepared and fixed in absolute methanol. The methanol-fixed slides were stained with acridine orange and coded. Slides were scanned to determine the 
frequency of micronucleated cells in 2,000 normochromatic erythrocytes (NCEs) in each of five animals per dose group. In addition, the percentage of polychromatic erythrocytes (PCEs; reticulocytes) in a population of 1,000 erythrocytes was determined as a measure of bone marrow toxicity.

Four or five male $\mathrm{B} 6 \mathrm{C} 3 \mathrm{~F} 1 / \mathrm{N}$ mice per dose group were administered 5-amino- $O$-cresol in corn oil by gavage at 24-hour intervals for 3 days; vehicle control animals received corn oil alone ${ }^{35 ; 51}$. The positive control was cyclophosphamide. Twenty-four hours after the final treatment, the animals were euthanized and smears of the bone marrow cells obtained from the femurs were prepared. Two trials were conducted.

For bone marrow slide evaluation, air-dried slides were fixed in absolute methanol and stained with acridine orange ${ }^{52}$. Two thousand PCEs were scored per animal for frequency of micronucleated cells. In addition, the percentage of PCEs among 500 erythrocytes in bone marrow was scored per animal as a measure of bone marrow toxicity.

The results were tabulated as the mean of the pooled results from all animals within a treatment group, plus or minus the standard error of the mean. The frequency of micronucleated cells among NCEs or PCEs was analyzed by a statistical software package that tested for increasing trend over dose groups using a one-tailed Cochran-Armitage trend test, followed by pairwise comparisons between each dosed group and the vehicle control group. In the presence of excess binomial variation, as detected by a binomial dispersion test, the binomial variance of the Cochran-Armitage test was adjusted upward in proportion to the excess variation. In the slidebased micronucleus test, an individual trial is considered positive if the trend test $\mathrm{P}$ value is less than or equal to 0.025 or if the $\mathrm{P}$ value for any single dosed group is less than or equal to 0.025 divided by the number of dosed groups. A final call of positive for micronucleus induction is preferably based on reproducibly positive trials (as noted above). Ultimately, the scientific staff determines the final call after considering the results of statistical analyses, reproducibility of any effects observed, and the magnitudes of those effects.

\section{Flow Cytometric Assay}

Blood samples (6 to $120 \mu \mathrm{L}$ ) were obtained from mice used in bone marrow trial 1 . Blood was drawn into tubes containing heparin, fixed in ultracold methanol, and frozen at $-80^{\circ} \mathrm{C}$ until analysis. Thawed blood samples were analyzed for frequency of micronucleated PCEs and NCEs using a flow cytometer ${ }^{35}$; both the mature erythrocyte population and the immature reticulocyte population can be accurately distinguished using flow cytometry by employing special cell surface markers to differentiate the two cell types. Approximately 20,000 PCEs and 1 million NCEs were analyzed per animal; the percentage of PCEs among circulating erythrocytes was also determined as a measure of bone marrow toxicity.

Based on prior experience with the large number of cells scored using flow cytometric scoring techniques $^{53}$, it is reasonable to assume that the proportion of micronucleated PCEs is approximately normally distributed. The statistical tests selected for trend and for pairwise comparisons with the vehicle control group depend on whether the variances among the groups are equal. Levene's test at $\alpha=0.05$ is used to test for equal variances. In the case of equal variances, linear regression is used to test for a linear trend with dose and Williams' test ${ }^{41 ; 42}$ is used to test for pairwise differences between each treated group and the vehicle control group. In the case of unequal variances, Jonckheere's test ${ }^{46}$ is used to test for linear trend and Dunn's test ${ }^{45}$ 
is used for pairwise comparisons of each treated group with the vehicle control group. Trend tests and pairwise comparisons with the vehicle controls are considered statistically significant at $\mathrm{P}=0.025$. Ultimately, the scientific staff determines the final call after considering the results of statistical analyses, reproducibility of any effects observed, and the magnitudes of those effects.

\section{Evaluation Protocol}

These are the basic guidelines for arriving at an overall assay result for assays performed by the National Toxicology Program. Statistical as well as biological factors are considered. For an individual assay, the statistical procedures for data analysis have been described in the preceding protocols. There have been instances, however, in which multiple aliquots of a chemical were tested in the same assay, and different results were obtained among these aliquots and/or among laboratories. Results from more than one aliquot or from more than one laboratory are not simply combined into an overall result. Rather, all the data are critically evaluated, particularly with regard to pertinent protocol variations, in determining the weight of evidence for an overall conclusion of chemical activity in an assay. In addition to multiple aliquots, the in vitro assays have another variable that must be considered in arriving at an overall test result. In vitro assays are conducted with and without exogenous metabolic activation. Results obtained in the absence of activation are not combined with results obtained in the presence of activation; each testing condition is evaluated separately. The results presented in the Abstract of this Toxicity Study Report represent a scientific judgment of the overall evidence for activity of the chemical in an assay. 


\section{Results}

\section{Three-month Study in Rats}

All rats survived to the end of the study (Table 2). Final mean body weights and body weight gains of male and female rats were similar to those of the vehicle controls (Table 2; Figure 3).

There were no biologically significant differences between dosed and vehicle control groups in hematology or clinical chemistry parameters of clinical pathology study rats on days 4 or 23 or core study rats at week 14 (Table B-1).

Absolute and relative liver weights and absolute heart weight were significantly increased in $8 \mathrm{mg} / \mathrm{kg}$ males relative to the vehicle controls (Table C-1). Because there were no microscopic lesions corresponding to these organ weight increases and the increases were not observed in the other dosed groups, these increases were not considered treatment related.

Administration of 8,16 , or $32 \mathrm{mg} / \mathrm{kg}$ did not result in significant changes/differences in reproductive organ histopathology, sperm parameters of male rats, or the estrous cyclicity of female rats when compared to the vehicle controls (Table D-1 and Table D-2). Therefore, 5-amino-o-cresol did not exhibit any potential to be a reproductive toxicant in male or female rats under the conditions of this study.

There were no gross or histologic lesions that were considered related to treatment (Table A-1 and Table A-2). Incidences of chronic active inflammation of the lung in $8 \mathrm{mg} / \mathrm{kg}$ males and histocytic inflammation of the mesenteric lymph node in $32 \mathrm{mg} / \mathrm{kg}$ females were significantly greater than those in the vehicle controls. These lesions were considered background changes, and therefore, not considered biologically relevant or treatment related. No gross or histologic lesions were recorded in the skin of rats. 
Table 2. Survival and Body Weights of Rats in the Three-month Dermal Study of 5-Amino-o-cresol ${ }^{\text {a }}$

\begin{tabular}{|c|c|c|c|c|c|}
\hline Dose (mg/kg) & Survival $^{b}$ & $\begin{array}{c}\text { Initial Body } \\
\text { Weight (g) }\end{array}$ & $\begin{array}{l}\text { Final Body } \\
\text { Weight (g) }\end{array}$ & $\begin{array}{l}\text { Change in Body } \\
\text { Weight (g) }\end{array}$ & $\begin{array}{l}\text { Final Weight } \\
\text { Relative to } \\
\text { Controls }(\%)\end{array}$ \\
\hline \multicolumn{6}{|l|}{ Male } \\
\hline 0 & $10 / 10$ & $77 \pm 1$ & $324 \pm 6$ & $247 \pm 5$ & \\
\hline 2 & $10 / 10$ & $78 \pm 1$ & $324 \pm 5$ & $247 \pm 5$ & 100 \\
\hline 4 & $10 / 10$ & $76 \pm 1$ & $329 \pm 7$ & $252 \pm 7$ & 101 \\
\hline 8 & $10 / 10$ & $77 \pm 1$ & $339 \pm 5$ & $262 \pm 5$ & 104 \\
\hline 16 & $10 / 10$ & $77 \pm 1$ & $333 \pm 7$ & $256 \pm 7$ & 103 \\
\hline 32 & $10 / 10$ & $77 \pm 1$ & $333 \pm 4$ & $256 \pm 4$ & 103 \\
\hline \multicolumn{6}{|l|}{ Female } \\
\hline 0 & $10 / 10$ & $74 \pm 1$ & $186 \pm 3$ & $112 \pm 2$ & \\
\hline 2 & $10 / 10$ & $74 \pm 1$ & $188 \pm 4$ & $114 \pm 3$ & 101 \\
\hline 4 & $10 / 10$ & $75 \pm 2$ & $192 \pm 3$ & $117 \pm 2$ & 103 \\
\hline 8 & $10 / 10$ & $74 \pm 1$ & $185 \pm 3$ & $112 \pm 2$ & 100 \\
\hline 16 & $10 / 10$ & $74 \pm 2$ & $187 \pm 4$ & $113 \pm 3$ & 101 \\
\hline 32 & $10 / 10$ & $73 \pm 1$ & $184 \pm 3$ & $111 \pm 3$ & 99 \\
\hline
\end{tabular}

${ }^{\mathrm{a}}$ Weights and weight changes are given as mean \pm standard error. Differences from the vehicle control group are not significant by Dunnett's test.

${ }^{b}$ Number of animals surviving at 14 weeks/number initially in group. 

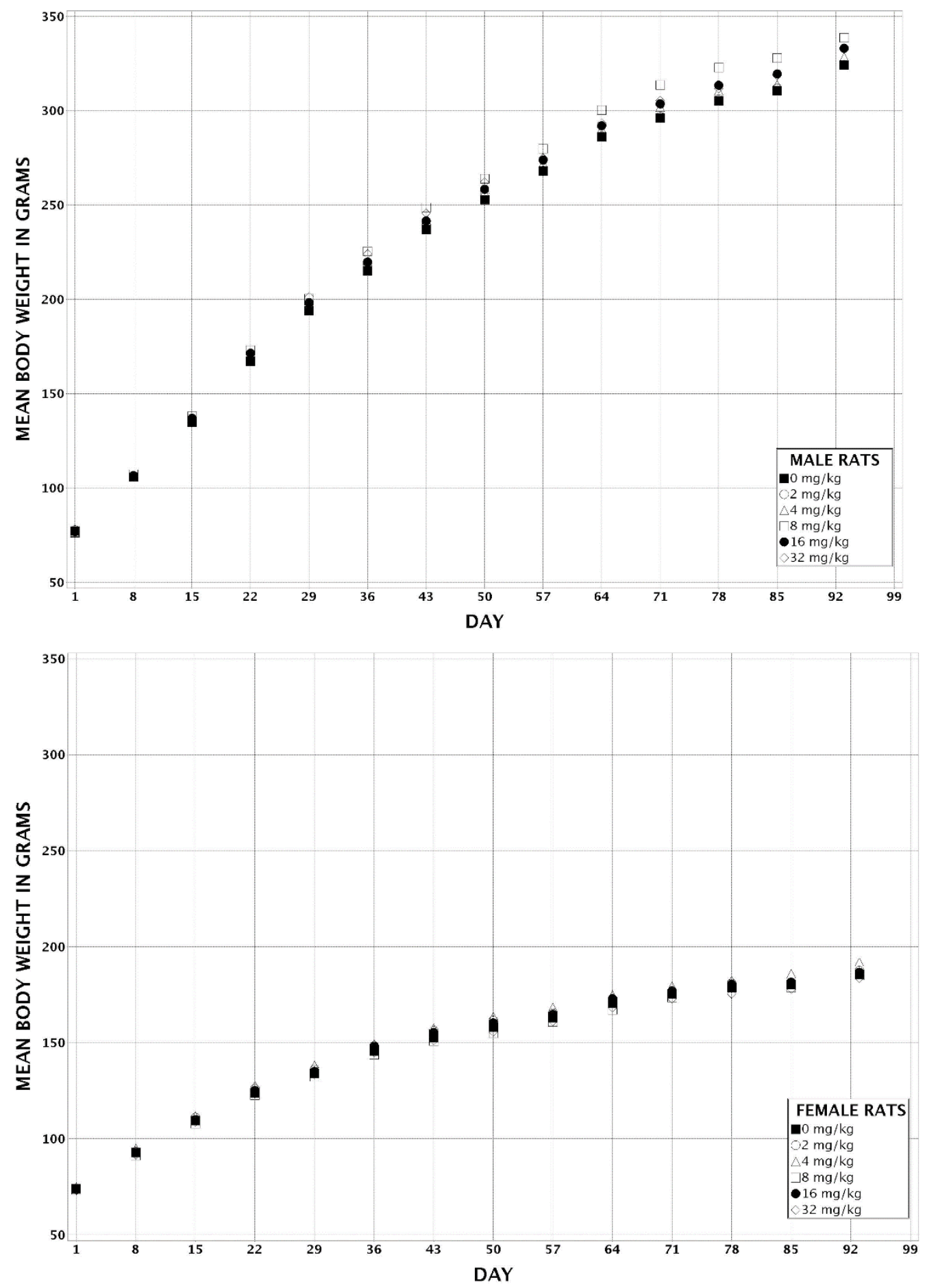

Figure 3. Growth Curves for Rats Administered 5-Amino-o-cresol Dermally for Three Months 


\section{Three-month Study in Mice}

All male mice survived to the end of the study (Table 3); one $32 \mathrm{mg} / \mathrm{kg}$ female mouse died spontaneously on day 73 . The final mean body weights and body weight gains of all dosed groups were similar to those of the vehicle control groups (Table 3; Figure 4). There were no treatment-related clinical findings in males or females. There were no statistically significant differences between dosed and vehicle control groups in hematology parameters (Table B-2) or in the absolute or relative organ weights (Table C-2).

Administration of 32,64 , or $128 \mathrm{mg} / \mathrm{kg}$ did not result in significant changes/differences in reproductive organ histopathology, sperm parameters of male mice, or the estrous cyclicity of female mice when compared to the vehicle controls (Table D-3 and Table D-4). Therefore, 5 -amino- $O$-cresol did not exhibit any potential to be a reproductive toxicant in male or female mice under the conditions of this study.

There were no gross or histologic lesions that were considered treatment related (Table A-3 and Table A-4). The female mouse that died early had a benign teratoma of the left ovary. Teratomas are spontaneous congenital neoplasms unrelated to chemical administration. No gross or histologic lesions were recorded in the skin of mice.

Table 3. Survival and Body Weights of Mice in the Three-month Dermal Study of 5-Amino-o-cresol ${ }^{\mathrm{a}}$

\begin{tabular}{cccccc}
\hline $\begin{array}{c}\text { Dose } \\
(\mathbf{m g} / \mathbf{k g})\end{array}$ & Survival $^{\mathbf{b}}$ & $\begin{array}{c}\text { Initial Body } \\
\text { Weight }(\mathbf{g})\end{array}$ & $\begin{array}{c}\text { Final Body } \\
\text { Weight }(\mathbf{g})\end{array}$ & $\begin{array}{c}\text { Change in Body } \\
\text { Weight }(\mathbf{g})\end{array}$ & $\begin{array}{c}\text { Final Weight Relative } \\
\text { to Controls }(\%)\end{array}$ \\
\hline Male & & & & & \\
0 & $10 / 10$ & $22.6 \pm 0.2$ & $41.8 \pm 0.8$ & $19.2 \pm 0.8$ & 98 \\
8 & $10 / 10$ & $22.8 \pm 0.3$ & $41.1 \pm 0.9$ & $18.4 \pm 0.9$ & 101 \\
16 & $10 / 10$ & $22.9 \pm 0.3$ & $42.3 \pm 0.7$ & $19.4 \pm 0.7$ & 102 \\
32 & $10 / 10$ & $23.0 \pm 0.3$ & $42.7 \pm 1.1$ & $19.7 \pm 1.0$ & 101 \\
64 & $10 / 10$ & $23.0 \pm 0.4$ & $42.1 \pm 1.0$ & $19.1 \pm 1.0$ & 102 \\
128 & $10 / 10$ & $23.0 \pm 0.2$ & $42.5 \pm 1.1$ & $19.5 \pm 1.0$ & 100 \\
\hline Female & & & & & 103 \\
0 & $10 / 10$ & $18.7 \pm 0.2$ & $37.6 \pm 1.0$ & $18.9 \pm 1.1$ & 104 \\
8 & $10 / 10$ & $18.6 \pm 0.2$ & $37.7 \pm 1.6$ & $19.1 \pm 1.5$ & 97 \\
32 & $10 / 10$ & $19.4 \pm 0.3$ & $38.8 \pm 1.1$ & $19.5 \pm 1.0$ & 96 \\
\hline 64 & $9 / 10^{c}$ & $19.1 \pm 0.2$ & $39.0 \pm 1.5$ & $19.9 \pm 1.5$ & $17.7 \pm 1.4$ \\
\hline
\end{tabular}

${ }^{a}$ Weights and weight changes are given as mean \pm standard error. Subsequent calculations are based on animals surviving to the end of the study. Differences from the vehicle control group are not significant by Dunnett's test.

${ }^{b}$ Number of animals surviving at 14 weeks/number initially in group.

${ }^{\mathrm{c}}$ Week of death: 11. 

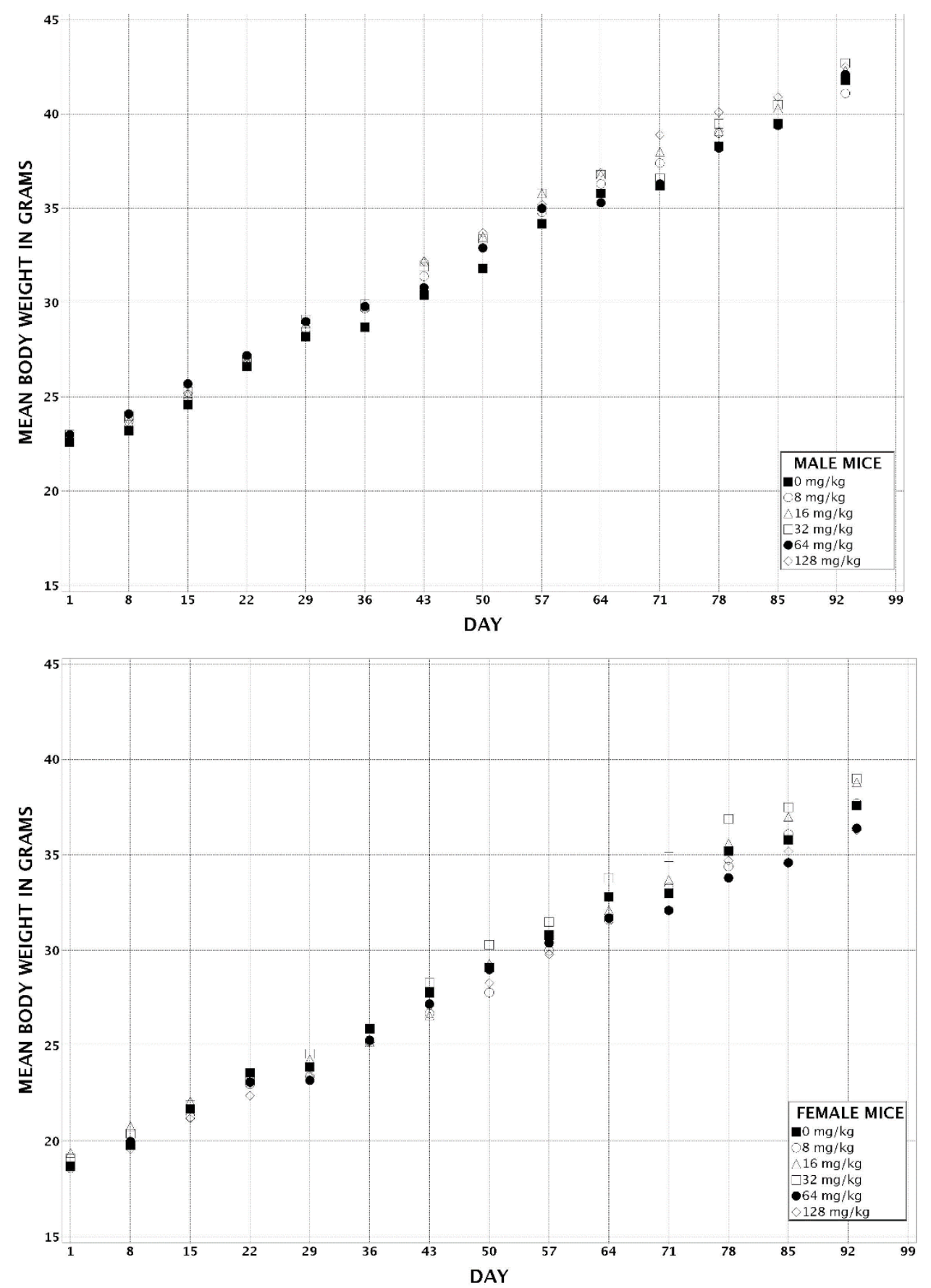

Figure 4. Growth Curves for Mice Administered 5-Amino-o-cresol Dermally for Three Months

\section{Genetic Toxicology}

5-Amino-o-cresol (33 to 6,666 $\mu \mathrm{g} /$ plate, dissolved in dimethylsulfoxide) was tested for mutagenicity in four strains of Salmonella typhimurium (TA97, TA98, TA100, and TA1535), with and without $10 \%$ induced male rat or hamster liver S9 enzymes; it was positive in strains TA97, TA98, and TA100 in the presence of either species of S9 ${ }^{34}$ (Table E-1). No mutagenicity was observed, however, in strain TA1535, with or without S9 activation enzymes. Among the 
three strains that gave positive responses, the strongest mutagenic response (based on fold-increase and lowest effective dose) was seen in strain TA98, a strain that reverts via frame shifting.

In vivo, no increases in micronucleated erythrocytes were observed in peripheral blood samples obtained from male or female B6C3F1/N mice in the 3-month toxicity study (Table E-2). In short-term tests for induction of micronuclei ${ }^{35}$ (Table E-3 and Table E-4), an initial test in male B6C3F1/N mice administered 5-amino-o-cresol (100 to $400 \mathrm{mg} / \mathrm{kg}$ per day) via gavage once daily for 3 days, was judged to be equivocal, based on a significant increase in micronucleated reticulocytes in bone marrow in the $100 \mathrm{mg} / \mathrm{kg}$ group (Table E-4; Trial 1). However, analysis of micronucleated reticulocytes in peripheral blood samples obtained from these same animals and measured using flow cytometry, showed no increases in micronuclei (Table E-3). In a repeat test, male B6C3F1/N mice were administered 50 to $400 \mathrm{mg} / \mathrm{kg} 5$-amino- $o$-cresol by gavage once daily for 3 days and no increases in the frequencies of micronucleated reticulocytes were observed over the dose range tested (Table E-4; Trial 2). No significant changes in the percentage of reticulocytes were seen in any of the micronucleus tests conducted with 5 -amino- $O$-cresol, suggesting that 5-amino- $O$-cresol did not induce bone marrow toxicity. 


\section{Discussion}

The toxic and carcinogenic properties of hair dyes and their components have previously been reviewed by the international community under the sponsorship of the International Agency for Research on Cancer (IARC) ${ }^{11 ; 26}$. Hair dyes may be classified into the following categories: oxidative (permanent) dyes, direct (temporary or semipermanent) dyes, and natural dyes ${ }^{11}$. Occupational exposures to hair dyes are probably carcinogenic to humans (classified as IARC Group 2A, "probably carcinogenic to humans"). Personal use of hair colorants is not classifiable as to its carcinogenicity to humans (IARC Group 3, "not classifiable as to its carcinogenicity to humans").

Because there had been no previous carcinogenesis studies on the oxidative hair dye, 5-amino- $O$-cresol, NTP conducted dermal toxicity studies to determine the level of toxicity in rodents and the need for 2-year dermal carcinogenicity studies.

The current NTP studies in F344/NTac rats and B6C3F1/N mice showed that skin toxicity did not occur after 3 months of dermal administration of 5-amino- $O$-cresol at doses up to $32 \mathrm{mg} / \mathrm{kg}$ body weight per day in rats and $128 \mathrm{mg} / \mathrm{kg}$ per day in mice. Mean body weights of dosed rats and mice were within $6 \%$ to $8 \%$ of the vehicle controls. No treatment-related mortality, gross or microscopic pathology findings, or effects on organ weights, clinical pathology endpoints, or reproductive endpoints were found in either species. While feed studies of 5-amino- $O$-cresol in rodents showed that when the chemical was administered at up to $3 \%(30,000 \mathrm{ppm})$ there was thyroid gland or liver toxicity in rats ${ }^{54}$, there was no evidence for these target organ toxicities in the current studies. NTP studies have shown that dermal absorption of 5-amino- $O$-cresol is about $10 \%$ when applied to a covered site; however, when the dose site is not covered, as was the case in the current studies, the absorption increases (up to 60\%) suggesting systemic exposure via both dermal and oral routes (due to grooming). Because the highest dose in this 5-amino-o-cresol rat study $(32 \mathrm{mg} / \mathrm{kg}$ per body weight) was considerably lower than the dose $(30,000 \mathrm{ppm})$ that caused liver and thyroid gland toxicity in the Christian ${ }^{54}$ feed study, no liver or thyroid gland toxicity was expected in the current rat study.

Other hair dye chemicals have been found to be carcinogenic in rodent studies, but for many of these studies the chemical was administered by the oral route of exposure to obtain a maximum systemic tolerated dose ${ }^{11 ; 55}$. In these studies of 5-amino- $O$-cresol, the dermal route of administration was selected to mimic human exposure. There was no evidence for 5-amino-o-cresol skin irritation in the dermal immunotoxicity studies. Chronic dermal irritation can lead to tumor promotion ${ }^{56-58}$, and in transgenic mouse cancer models, skin irritation may lead to a dermal carcinogenic response ${ }^{59 ; 60}$. However, in these studies there was no indication of 5 -amino- $O$-cresol skin irritation or skin toxicity. Although 5-amino-o-cresol is mutagenic in bacteria, not all bacterial mutagens are carcinogenic in rodent bioassays ${ }^{61 ; 62}$. While 5-amino-o-cresol was mutagenic in some of the Salmonella strains tested, it is not anticipated to be a rodent carcinogen by the dermal route of administration based on the lack of target organ lesions in the 3-month dermal 5-amino-o-cresol studies reported here and the limited 5-amino- $O$-cresol absorption by skin. 


\section{References}

1. Hazardous Substances Data Bank (HSDB) entry for: 5-Amino-o-cresol. National Institutes for Occupational Safety and Health (NIOSH); 2012. http://toxnet.nlm.nih.gov/cgibin/sis/search2/r?dbs+hsdb: @term+@DOCNO+7152

2. Lewis R. Sax's dangerous properties of industrial materials. 10th ed. New York, NY: John Wiley and Sons, Inc; 1999.

3. United States Environmental Protection Agency (USEPA). Estimation Programs Interface Suite $^{\mathrm{TM}}$ for Microsoft ${ }^{\circledR}$ Windows, v 3.10. Washington, DC: US Environmental Protection Agency; 2001.

4. Corbett JF. An historical review of the use of dye precursors in the formulation of commercial oxidation hair dyes. Dyes Pigments. 1999; 41(1-2):127-136. http://dx.doi.org/10.1016/S0143$\underline{7208(98) 00075-8}$

5. Cosmetic Ingredient Review (CIR) Expert Panel. Annual review of cosmetic ingredient safety assessments: 2005/2006. Int J Toxicol. 2008; 27:77. http://dx.doi.org/10.1080/10915810802032362

6. Corbett JF. Synthetic dyes for human hair In: Freeman H, Peters A, editors. Colorants for nontextile applications. Amsterdam, Netherlands: Elsevier BV; 2000. p. 456-477. http://dx.doi.org/10.1016/B978-044482888-0/50041-6

7. Bureau of Labor Statistics (BLS). Quick facts: Barbers, hairdressers, and cosmetologists. Occupational Outlook Handbook, 2012-2013 ed. Washington, DC: United States Department of Labor; 2012. http://www.bls.gov/ooh/personal-care-and-service/barbers-hairdressers-andcosmetologists.htm.

8. National Cancer Institute (NCI). Hair dyes and cancer risk. Bethesda, MD: National Institutes of Health; 2011. http://www.cancer.gov/cancertopics/factsheet/Risk/hair-dyes [Accessed: September 25, 2012]

9. Huncharek M, Kupelnick B. Personal use of hair dyes and the risk of bladder cancer: Results of a meta-analysis. Public Health Rep. 2005; 120(1):31-38.

http://dx.doi.org/10.1177/003335490512000107

10. National Institute for Occupational Safety and Health (NIOSH). National Occupational Exposure Survey (1981-1983) [unpublished provisional data]. Cincinnati, OH. 1990.

11. International Agency for Research on Cancer (IARC). IARC Monographs on the Evaluation of Carcinogenic Risks to Humans. Occupational exposures of hairdressers and barbers and personal use of hair colourants. Lyon, France: IARC; 2010.

12. Food and Drug Administation (FDA). Hair dye products. 1997. https://web.archive.org/web/20090609102656/http://www.fda.gov/cosmetics/productandingredie ntsafety/productinformation/ucm143066.htm [Accessed: September 28, 2012] 
13. Akerson J, Pohl S, Varco J, Wallace P, Wolfram L. Hair preparations In: Kroschwitz J, Howe-Grant M, editors. Kirk-Othmer Encyclopedia of Chemical Technology, 4th ed. New York, NY: John Wiley \& Sons Inc; 1994. p. 881-918.

14. Code of Federal Regulations (CFR). 21:Part 73.

15. Code of Federal Regulations (CFR). 21:Part 74.

16. Meadows M. Heading off hair-care disasters. Use caution with relaxers and dyes. FDA Consum. 2001; 35(1):21-24.

17. Konrad E, Mager H, Hoffmann A, inventors. Composition and method for the oxidative dyeing of hair. United States patent 4,883,656; 1989

18. Hedtke B, Gao Z, Chen L-J, Weber W, Dix K. Metabolism and disposition of [14C] 5amino-o-cresol in female F344 rats and B6C3F1 mice. Xenobiotica. 2008; 38(2):171-184. http://dx.doi.org/10.1080/00498250701744666

19. Goebel C, Hewitt N, Kunze G, Wenker M, Hein D, Beck H, Skare J. Skin metabolism of aminophenols: Human keratinocytes as a suitable in vitro model to qualitatively predict the dermal transformation of 4-amino-2-hydroxytoluene in vivo. Toxicol App Pharmacol. 2009; 235(1):114-123. http://dx.doi.org/10.1016/j.taap.2008.11.014

20. Wolfram L, Maibach H. Percutaneous penetration of hair dyes. Arch Dermatol Res. 1985; 277(3):235-241. http://dx.doi.org/10.1007/BF00404323

21. Eggenreich K, Golouch S, Töscher B, Beck H, Kuehnelt D, Wintersteiger R. Determination of 4-amino-m-cresol and 5-amino-o-cresol and metabolites in human keratinocytes (HaCaT) by high-performance liquid chromatography with DAD and MS detection. J Biochem Biophys Methods. 2004; 61(1-2):23-34. http://dx.doi.org/10.1016/j.jbbm.2004.04.021

22. Ogiso T, Shiraki T, Okajima K, Tanino T, Iwaki M, Wada T. Transfollicular drug delivery: Penetration of drugs through human scalp skin and comparison of penetration between scalp and abdominal skins in vitro. J Drug Target. 2002; 10(5):369-378.

http://dx.doi.org/10.1080/1061186021000001814

23. Lloyd G, Ligget M, Kynoch S, Davies R. Assessment of the acute toxicity and potential irritancy of hair dye constituents. Food Cosmet Toxicol. 1977; 15(6):607-610. http://dx.doi.org/10.1016/0015-6264(77)90077-3

24. National Toxicology Program (NTP). Final report. Assessment of contact hypersensitivity to 5 amino-o-cresol in female BALB/c mice. Richmond, VA: Prepared by: Medical College of Virginia, VCU; 2006.

25. Takkouche B, Regueira-Méndez C, Montes-Martínez A. Risk of cancer among hairdressers and related workers: A meta-analysis. Int J Epidemiol. 2009; 38(6):1512-1531. http://dx.doi.org/10.1093/ije/dyp283

26. International Agency for Research on Cancer (IARC). IARC Monographs on the Evaluation of Carcinogenic Risks to Humans. Some hair dyes, cosmetic colourants, industrial dyestuffs, and 
aromatic amines. In: Occupational Exposures of Hairdressers and Barbers and Personal Use of Hair Colorants. Lyon, France: IARC; 1993. p. 43-118.

27. Altekruse SF, Henley SJ, Thun MJ. Deaths from hematopoietic and other cancers in relation to permanent hair dye use in a large prospective study (United States). Cancer Causes Control. 1999; 10(6):617-625. http://dx.doi.org/10.1023/A:1008926027805

28. Gago-Dominguez M, Bell DA, Watson MA, Yuan J-M, Castelao JE, Hein DW, Chan KK, Coetzee GA, Ross RK, Yu MC. Permanent hair dyes and bladder cancer: Risk modification by cytochrome P4501A2 and N-acetyltransferases 1 and 2. Carcinogenesis. 2003; 24(3):483-489. http://dx.doi.org/10.1093/carcin/24.3.483

29. Gago-Dominguez M, Castelao JE, Yuan JM, Yu MC, Ross RK. Use of permanent hair dyes and bladder-cancer risk. Int J Cancer. 2001; 91(4):575-579. http://dx.doi.org/10.1002/10970215(200002)9999:9999<::AID-IJC1092>3.0.CO;2-S

30. Heineman EF, Ward MH, McComb RD, Weisenburger DD, Zahm SH. Hair dyes and risk of glioma among Nebraska women. Cancer Causes Control. 2005; 16(7):857-864.

http://dx.doi.org/10.1007/s10552-005-3204-z

31. Zahm S, Blair A, Fraumini J. Hair coloring products: Safe or still suspect? J Natl Cancer Inst. 1994; 86(12):941-943. http://dx.doi.org/10.1093/jnci/86.12.941-a

32. Zahm SH, Weisenburger DD, Babbitt PA, Saal RC, Vaught JB, Blair A. Use of hair coloring products and the risk of lymphoma, multiple myeloma, and chronic lymphocytic leukemia. Am J Public Health. 1992; 82(7):990-997. http://dx.doi.org/10.2105/AJPH.82.7.990

33. Zhang Y, Holford TR, Leaderer B, Boyle P, Zahm SH, Flynn S, Tallini G, Owens PH, Zheng T. Hair-coloring product use and risk of non-Hodgkin's lymphoma: A population-based casecontrol study in Connecticut. Am J Epidemiol. 2004; 159(2):148-154.

http://dx.doi.org/10.1093/aje/kwh033

34. Zeiger E, Anderson B, Haworth S, Lawlor T, Mortelmans K. Salmonella mutagenicity tests. IV. Results from the testing of 300 chemicals. Environ Mol Mutagen. 1988; 11(S12):1-18. http://dx.doi.org/10.1002/em.2850110602

35. Witt KL, Livanos E, Kissling GE, Torous DK, Caspary W, Tice RR, Recio L. Comparison of flow cytometry-and microscopy-based methods for measuring micronucleated reticulocyte frequencies in rodents treated with nongenotoxic and genotoxic chemicals. Mutat Res. 2008; 649(1):101-113. http://dx.doi.org/10.1016/j.mrgentox.2007.08.004

36. Research Triangle Institute (RTI). Preliminary chemistry studies report. Research Triangle Park, NC: RTI; 2003. NIH Contract No. N01-ES-05455, RTI Project No. 07939.004.016.

37. Maronpot R, Boorman G. Interpretation of rodent hepatocellular proliferative alterations and hepatocellular tumors in chemical safety assessment. Toxicol Pathol. 1982; 10(2):71-78. http://dx.doi.org/10.1177/019262338201000210

38. Boorman GA, Montgomery CA, Jr., Eustis SL, Wolfe MJ, McConnell EE, Hardisty JF. Quality assurance in pathology for rodent carcinogenicity studies. In: Milman HA, Weisburger 
EK, editors. Handbook of carcinogen testing. Park Ridge, NJ: Noyes Publications; 1985. p. 345357.

39. Gart JJ, Chu KC, Tarone RE. Statistical issues in interpretation of chronic bioassay tests for carcinogenicity. J Natl Cancer Inst. 1979; 62(4):957-974.

40. Dunnett CW. A multiple comparison procedure for comparing several treatments with a control. J American Stat Assoc. 1955; 50(272):1096-1121.

http://dx.doi.org/10.1080/01621459.1955.10501294

41. Williams D. The comparison of several dose levels with a zero dose control. Biometrics. 1972; 28(2):519-531. http://dx.doi.org/10.2307/2556164

42. Williams D. A test for differences between treatment means when several dose levels are compared with a zero dose control. Biometrics. 1971; 27(1):103-117. http://dx.doi.org/10.2307/2528930

43. Shirley E. A non-parametric equivalent of Williams' test for contrasting increasing dose levels of a treatment. Biometrics. 1977:386-389. http://dx.doi.org/10.2307/2529789

44. Williams D. A note on Shirley's nonparametric test for comparing several dose levels with a zero-dose control. Biometrics. 1986; 42(1):183-186. http://dx.doi.org/10.2307/2531254

45. Dunn OJ. Multiple comparisons using rank sums. Technometrics. 1964; 6(3):241-252. http://dx.doi.org/10.1080/00401706.1964.10490181

46. Jonckheere A. A distribution-free k-sample test against ordered alternatives. Biometrika. 1954; 41:133-145. http://dx.doi.org/10.1093/biomet/41.1-2.133

47. Dixon W, Massey F. Introduction to statistical analysis. New York, NY: McGraw Hill Book Company Inc; 1957.

48. Girard D, Sager D. The use of Markov chains to detect subtle variation in reproductive cycling. Biometrics. 1987:225-234. http://dx.doi.org/10.2307/2531963

49. Code of Federal Regulations (CFR). 21:Part 58.

50. MacGregor JT, Wehr CM, Henika PR, Shelby MD. The in vivo erythrocyte micronucleus test: Measurement at steady state increases assay efficiency and permits integration with toxicity studies. Fundam Appl Toxicol. 1990; 14(3):513-522. http://dx.doi.org/10.1016/0272$\underline{0590(90) 90255-\mathrm{I}}$

51. Shelby M, Erexson G, Hook G, Tice R. Evaluation of a three-exposure mouse bone marrow micronucleus protocol: Results with 49 chemicals. Environ Mol Mutagen. 1993; 21(2):160-179. http://dx.doi.org/10.1002/em.2850210210

52. Hayashi M, Sofuni T, Ishidate Jr M. An application of acridine orange fluorescent staining to the micronucleus test. Mutat Res Lett. 1983; 120(4):241-247. http://dx.doi.org/10.1016/01657992(83)90096-9 
53. Kissling GE, Dertinger SD, Hayashi M, MacGregor JT. Sensitivity of the erythrocyte micronucleus assay: Dependence on number of cells scored and inter-animal variability. Mutat Res. 2007; 634(1):235-240. http://dx.doi.org/10.1016/j.mrgentox.2007.07.010

54. Christian M. Final report on the safety assessment of 4-amino-2-hydroxytoluene. J Am Coll Toxicol. 1989; 8(4):569-587. http://dx.doi.org/10.3109/10915818909010523

55. Baan R, Straif K, Grosse Y, Secretan B, El Ghissassi F, Bouvard V, Benbrahim-Tallaa L, Cogliano V. Carcinogenicity of some aromatic amines, organic dyes, and related exposures. The Lancet Oncol. 2008; 9(4):322-323. http://dx.doi.org/10.1016/S1470-2045(08)70089-5

56. Argyris TS, Klein-Szanto A. Regeneration and the mechanism of epidermal tumor promotion. CRC Crit Rev Toxicol. 1985; 14(3):211-258.

http://dx.doi.org/10.3109/10408448509037459

57. Hennings H, Boutwell R. Studies on the mechanism of skin tumor promotion. Cancer Res. 1970; 30(2):312-320.

58. Pullinger B. A measure of the stimulating effect of simple injury combined with carcinogenic chemicals on tumour formation in mice. J Pathol Bacteriol. 1945; 57(4):477-481.

http://dx.doi.org/10.1002/path.1700570411

59. Cannon RE, Spalding JW, Trempus CS, Szczesniak CJ, Virgil KM, Humble MC, Tennant RW. Kinetics of wound-induced v-Ha-ras transgene expression and papilloma development in transgenic Tg. AC mice. Mol Carcinog. 1997; 20(1):108-114.

http://dx.doi.org/10.1002/(SICI)1098-2744(199709)20:1<108::AID-MC12>3.0.CO;2-5

60. Tennant RW, Stasiewicz S, Eastin WC, Mennear JH, Spalding JW. The Tg. AC (v-Ha-ras) transgenic mouse: Nature of the model. Toxicol Pathol. 2001; 29(1_suppl):51-59.

http://dx.doi.org/10.1080/019262301753178474

61. Tennant RW, Margolin BH, Shelby MD, Zeiger E, Haseman JK, Spalding J, Caspary W, Resnick M, Stasiewicz S, Anderson B et al. Prediction of chemical carcinogenicity in rodents from in vitro genetic toxicity assays. Science. 1987; 236(4804):933-941.

http://dx.doi.org/10.1126/science.3554512

62. Zeiger E. Mutagens that are not carcinogens: Faulty theory or faulty tests? Mutat Res. 2001; 492(1):29-38. http://dx.doi.org/10.1016/S1383-5718(01)00153-X

63. Hayamizu K, Yanagisawa M, Yamamoto O, Wasada N, Someno K, Tanabe K, Tamura T, Hiraishi J. National Institute of Advanced Industrial Science and Technology. Tsukuba, Ibaraki, Japan; 2006. www.aist.go.jp/RIODB/SDBS/menu-e.html

64. The Aldrich library of infrared spectra. Pouchert CJ, editor. Milwaukee, WI: Aldrich Chemical Company Inc.; 1981. 


\section{Appendix A. Summary of Lesions in Rats and Mice}

\section{Tables}

Table A-1. Summary of the Incidence of Nonneoplastic Lesions in Male Rats in the Three-month Dermal Study of 5-Amino-o-cresol.

Table A-2. Summary of the Incidence of Nonneoplastic Lesions in Female Rats in the Three-month Dermal Study of 5-Amino- $o$-cresol.

Table A-3. Summary of the Incidence of Nonneoplastic Lesions in Male Mice in the Three-month Dermal Study of 5-Amino-o-cresol....

Table A-4. Summary of the Incidence of Neoplasms and Nonneoplastic Lesions in

Female Mice in the Three-month Dermal Study of 5-Amino- $o$-cresol 
Table A-1. Summary of the Incidence of Nonneoplastic Lesions in Male Rats in the Three-month Dermal Study of 5-Amino-o-cresol ${ }^{\mathrm{a}}$

\begin{tabular}{|c|c|c|c|c|c|c|}
\hline & $\begin{array}{l}\text { Vehicle } \\
\text { Control }\end{array}$ & $2 \mathrm{mg} / \mathrm{kg}$ & $4 \mathrm{mg} / \mathrm{kg}$ & $8 \mathrm{mg} / \mathrm{kg}$ & $16 \mathrm{mg} / \mathrm{kg}$ & $32 \mathrm{mg} / \mathrm{kg}$ \\
\hline \multicolumn{7}{|l|}{ Disposition Summary } \\
\hline Animals initially in study & 10 & 10 & 10 & 10 & 10 & 10 \\
\hline \multicolumn{7}{|l|}{ Survivors } \\
\hline Terminal kill & 10 & 10 & 10 & 10 & 10 & 10 \\
\hline $\begin{array}{l}\text { Animals examined } \\
\text { microscopically }\end{array}$ & 10 & 10 & 10 & 10 & 10 & 10 \\
\hline \multicolumn{7}{|l|}{ Alimentary System } \\
\hline Esophagus & $(10)$ & $(0)$ & (0) & (0) & $(0)$ & (10) \\
\hline Intestine large, cecum & (10) & (0) & (0) & (0) & $(0)$ & (10) \\
\hline Intestine large, colon & (10) & (0) & (0) & (0) & $(0)$ & (10) \\
\hline Intestine large, rectum & $(10)$ & $(0)$ & $(0)$ & $(0)$ & $(0)$ & (10) \\
\hline Parasite metazoan & - & - & - & - & - & $2(20 \%)$ \\
\hline Intestine small, duodenum & $(10)$ & (0) & (0) & (0) & $(0)$ & (10) \\
\hline Intestine small, ileum & $(10)$ & $(0)$ & (0) & $(0)$ & $(0)$ & $(10)$ \\
\hline Intestine small, jejunum & (10) & $(0)$ & (0) & $(0)$ & $(0)$ & (10) \\
\hline Liver & $(10)$ & $(10)$ & $(10)$ & $(10)$ & $(10)$ & $(10)$ \\
\hline Hepatodiaphragmatic nodule & - & - & - & $1(10 \%)$ & - & - \\
\hline Inflammation, chronic active & $9(90 \%)$ & - & - & $1(10 \%)$ & - & $9(90 \%)$ \\
\hline Pancreas & $(10)$ & (0) & (0) & $(0)$ & $(0)$ & $(10)$ \\
\hline Inflammation, chronic active & $1(10 \%)$ & - & - & - & - & - \\
\hline Acinus, atrophy & - & - & - & - & - & $2(20 \%)$ \\
\hline Salivary glands & $(10)$ & $(0)$ & (0) & $(0)$ & $(0)$ & (10) \\
\hline Stomach, forestomach & (10) & (0) & (0) & (0) & $(0)$ & (10) \\
\hline Stomach, glandular & $(10)$ & $(0)$ & $(0)$ & $(0)$ & $(0)$ & $(10)$ \\
\hline \multicolumn{7}{|l|}{ Cardiovascular System } \\
\hline Blood vessel & $(10)$ & $(0)$ & (0) & (0) & $(0)$ & (10) \\
\hline Heart & $(10)$ & (0) & (0) & (0) & (0) & $(10)$ \\
\hline Cardiomyopathy & $10(100 \%)$ & - & - & - & - & $10(100 \%)$ \\
\hline \multicolumn{7}{|l|}{ Endocrine System } \\
\hline Adrenal cortex & $(10)$ & $(0)$ & $(0)$ & $(0)$ & $(0)$ & (10) \\
\hline Adrenal medulla & $(10)$ & $(0)$ & $(0)$ & $(0)$ & $(0)$ & $(10)$ \\
\hline $\begin{array}{l}\text { Infiltration cellular, } \\
\text { mononuclear cell }\end{array}$ & $1(10 \%)$ & - & - & - & - & $2(20 \%)$ \\
\hline Islets, pancreatic & (10) & $(0)$ & $(0)$ & $(0)$ & (0) & (10) \\
\hline
\end{tabular}




\begin{tabular}{|c|c|c|c|c|c|c|}
\hline & $\begin{array}{l}\text { Vehicle } \\
\text { Control }\end{array}$ & $2 \mathrm{mg} / \mathrm{kg}$ & $4 \mathrm{mg} / \mathrm{kg}$ & $8 \mathrm{mg} / \mathrm{kg}$ & $16 \mathrm{mg} / \mathrm{kg}$ & $32 \mathrm{mg} / \mathrm{kg}$ \\
\hline Parathyroid gland & (9) & $(0)$ & $(0)$ & $(0)$ & $(0)$ & (9) \\
\hline Pituitary gland & (10) & (0) & $(0)$ & $(0)$ & $(0)$ & (10) \\
\hline Cyst & $1(10 \%)$ & - & - & - & - & - \\
\hline Thyroid gland & $(10)$ & (10) & (10) & (10) & (10) & (10) \\
\hline $\begin{array}{l}\text { Infiltration cellular, } \\
\text { mononuclear cell }\end{array}$ & - & - & - & - & - & $1(10 \%)$ \\
\hline \multicolumn{7}{|l|}{ General Body System } \\
\hline None & - & - & - & - & - & - \\
\hline \multicolumn{7}{|l|}{ Genital System } \\
\hline Epididymis & $(10)$ & $(0)$ & (0) & (0) & (0) & (10) \\
\hline $\begin{array}{l}\text { Infiltration cellular, } \\
\text { mononuclear cell }\end{array}$ & $1(10 \%)$ & - & - & - & - & - \\
\hline Inflammation, chronic active & - & - & - & - & - & $2(20 \%)$ \\
\hline Preputial gland & (10) & $(0)$ & $(0)$ & (0) & (0) & $(10)$ \\
\hline Prostate & (10) & (0) & (0) & (0) & (0) & (10) \\
\hline Seminal vesicle & (10) & $(0)$ & $(0)$ & $(0)$ & $(0)$ & (10) \\
\hline Testes & (10) & (0) & $(0)$ & $(0)$ & $(0)$ & (10) \\
\hline \multicolumn{7}{|l|}{ Hematopoietic System } \\
\hline Bone marrow & (10) & (0) & (0) & (0) & (0) & (10) \\
\hline Lymph node, mandibular & (10) & (0) & $(0)$ & $(0)$ & (0) & (10) \\
\hline Lymph node, mesenteric & (10) & $(0)$ & $(0)$ & $(0)$ & (0) & (10) \\
\hline Inflammation, histiocytic & - & - & - & - & - & $1(10 \%)$ \\
\hline Spleen & (10) & (0) & (0) & (0) & (0) & (10) \\
\hline Thymus & (10) & $(0)$ & $(0)$ & $(0)$ & $(0)$ & (10) \\
\hline \multicolumn{7}{|l|}{ Integumentary System } \\
\hline Mammary gland & (10) & (0) & (0) & (0) & (0) & (10) \\
\hline Skin & (10) & $(0)$ & $(0)$ & $(0)$ & $(0)$ & (10) \\
\hline \multicolumn{7}{|l|}{ Musculoskeletal System } \\
\hline Bone & $(10)$ & $(0)$ & $(0)$ & $(0)$ & $(0)$ & (10) \\
\hline \multicolumn{7}{|l|}{ Nervous System } \\
\hline Brain & $(10)$ & $(0)$ & $(0)$ & $(0)$ & $(0)$ & $(10)$ \\
\hline \multicolumn{7}{|l|}{ Respiratory System } \\
\hline Lung & $(10)$ & $(10)$ & (10) & (10) & (10) & $(10)$ \\
\hline Infiltration cellular, histiocyte & $2(20 \%)$ & - & - & - & - & $4(40 \%)$ \\
\hline Inflammation, chronic active & $3(30 \%)$ & $5(50 \%)$ & $7(70 \%)$ & $8(80 \%)$ & $6(60 \%)$ & $5(50 \%)$ \\
\hline
\end{tabular}


5-Amino-o-cresol, NTP TOX 89

\begin{tabular}{|c|c|c|c|c|c|c|}
\hline & $\begin{array}{l}\text { Vehicle } \\
\text { Control }\end{array}$ & $2 \mathrm{mg} / \mathrm{kg}$ & $4 \mathrm{mg} / \mathrm{kg}$ & $8 \mathrm{mg} / \mathrm{kg}$ & $16 \mathrm{mg} / \mathrm{kg}$ & $32 \mathrm{mg} / \mathrm{kg}$ \\
\hline Metaplasia, osseous & $2(20 \%)$ & - & - & - & - & $1(10 \%)$ \\
\hline Nose & $(10)$ & (0) & (0) & (0) & $(0)$ & (10) \\
\hline Trachea & (10) & $(0)$ & (0) & (0) & $(0)$ & (10) \\
\hline $\begin{array}{l}\text { Infiltration cellular, } \\
\text { mononuclear cell }\end{array}$ & $5(50 \%)$ & - & - & - & - & $3(30 \%)$ \\
\hline \multicolumn{7}{|l|}{ Special Senses System } \\
\hline Eye & $(10)$ & $(0)$ & (0) & (0) & $(0)$ & (10) \\
\hline Harderian gland & (10) & (0) & (0) & $(0)$ & $(0)$ & (10) \\
\hline $\begin{array}{l}\text { Infiltration cellular, } \\
\text { mononuclear cell }\end{array}$ & - & - & - & - & - & $1(10 \%)$ \\
\hline Inflammation, chronic active & $1(10 \%)$ & - & - & - & - & $1(10 \%)$ \\
\hline \multicolumn{7}{|l|}{ Urinary System } \\
\hline Kidney & (10) & (0) & (0) & (0) & $(0)$ & (10) \\
\hline $\begin{array}{l}\text { Infiltration cellular, } \\
\text { mononuclear cell }\end{array}$ & $1(10 \%)$ & - & - & - & - & $1(10 \%)$ \\
\hline Mineralization & $6(60 \%)$ & - & - & - & - & $6(60 \%)$ \\
\hline Nephropathy & $10(100 \%)$ & - & - & - & - & $10(100 \%)$ \\
\hline Urinary bladder & (10) & $(0)$ & $(0)$ & $(0)$ & (0) & (10) \\
\hline
\end{tabular}


Table A-2. Summary of the Incidence of Nonneoplastic Lesions in Female Rats in the Three-month Dermal Study of 5-Amino-o-cresol ${ }^{\mathrm{a}}$

\begin{tabular}{|c|c|c|c|c|c|c|}
\hline & $\begin{array}{l}\text { Vehicle } \\
\text { Control }\end{array}$ & $2 \mathrm{mg} / \mathrm{kg}$ & $4 \mathrm{mg} / \mathrm{kg}$ & $8 \mathrm{mg} / \mathrm{kg}$ & $16 \mathrm{mg} / \mathrm{kg}$ & $32 \mathrm{mg} / \mathrm{kg}$ \\
\hline \multicolumn{7}{|l|}{ Disposition Summary } \\
\hline Animals initially in study & 10 & 10 & 10 & 10 & 10 & 10 \\
\hline \multicolumn{7}{|l|}{ Survivors } \\
\hline Terminal kill & 10 & 10 & 10 & 10 & 10 & 10 \\
\hline $\begin{array}{c}\text { Animals examined } \\
\text { microscopically }\end{array}$ & 10 & 10 & 10 & 10 & 10 & 10 \\
\hline \multicolumn{7}{|l|}{ Alimentary System } \\
\hline Esophagus & $(10)$ & (0) & $(0)$ & $(0)$ & (0) & $(10)$ \\
\hline Intestine large, cecum & $(10)$ & (0) & $(0)$ & $(0)$ & (0) & (10) \\
\hline Intestine large, colon & $(10)$ & (0) & $(0)$ & $(0)$ & (0) & (10) \\
\hline Intestine large, rectum & $(10)$ & (0) & $(0)$ & $(0)$ & (0) & $(10)$ \\
\hline Parasite metazoan & $1(10 \%)$ & - & - & - & - & - \\
\hline Intestine small, duodenum & $(10)$ & (0) & $(0)$ & $(0)$ & (0) & $(10)$ \\
\hline Intestine small, ileum & $(10)$ & (0) & $(0)$ & $(0)$ & (0) & (10) \\
\hline Intestine small, jejunum & $(10)$ & (0) & $(0)$ & $(0)$ & $(0)$ & $(10)$ \\
\hline Liver & $(10)$ & $(10)$ & $(10)$ & $(10)$ & $(10)$ & $(10)$ \\
\hline $\begin{array}{l}\text { Hematopoietic cell } \\
\text { proliferation }\end{array}$ & - & - & - & $1(10 \%)$ & - & - \\
\hline Hepatodiaphragmatic nodule & $2(20 \%)$ & $3(30 \%)$ & $2(20 \%)$ & $3(30 \%)$ & $2(20 \%)$ & $1(10 \%)$ \\
\hline Inflammation, chronic active & $10(100 \%)$ & $1(10 \%)$ & $2(20 \%)$ & $2(20 \%)$ & $2(20 \%)$ & $10(100 \%)$ \\
\hline Pancreas & $(10)$ & (0) & $(0)$ & $(0)$ & (0) & $(10)$ \\
\hline Acinus, atrophy & $2(20 \%)$ & - & - & - & - & $1(10 \%)$ \\
\hline Salivary glands & $(10)$ & (0) & $(0)$ & $(0)$ & $(0)$ & $(10)$ \\
\hline $\begin{array}{l}\text { Infiltration cellular, } \\
\text { mononuclear cell }\end{array}$ & - & - & - & - & - & $1(10 \%)$ \\
\hline Stomach, forestomach & $(10)$ & $(0)$ & $(0)$ & $(0)$ & (0) & $(10)$ \\
\hline Stomach, glandular & $(10)$ & $(0)$ & $(0)$ & $(0)$ & $(0)$ & $(10)$ \\
\hline \multicolumn{7}{|l|}{ Cardiovascular System } \\
\hline Blood vessel & $(10)$ & (0) & $(0)$ & $(0)$ & $(0)$ & $(10)$ \\
\hline Heart & $(10)$ & $(0)$ & $(0)$ & $(0)$ & $(0)$ & $(10)$ \\
\hline Cardiomyopathy & $10(100 \%)$ & - & - & - & - & $9(90 \%)$ \\
\hline
\end{tabular}




\begin{tabular}{|c|c|c|c|c|c|c|}
\hline & $\begin{array}{l}\text { Vehicle } \\
\text { Control }\end{array}$ & $2 \mathrm{mg} / \mathrm{kg}$ & $4 \mathrm{mg} / \mathrm{kg}$ & $8 \mathrm{mg} / \mathrm{kg}$ & $16 \mathrm{mg} / \mathrm{kg}$ & $32 \mathrm{mg} / \mathrm{kg}$ \\
\hline \multicolumn{7}{|l|}{ Endocrine System } \\
\hline Adrenal cortex & $(10)$ & (0) & (0) & (0) & $(0)$ & (10) \\
\hline Adrenal medulla & (10) & $(0)$ & $(0)$ & $(0)$ & $(0)$ & $(10)$ \\
\hline Islets, pancreatic & $(10)$ & $(0)$ & $(0)$ & (0) & $(0)$ & (10) \\
\hline Parathyroid gland & (7) & $(0)$ & $(0)$ & (0) & $(0)$ & (8) \\
\hline Pituitary gland & (10) & $(0)$ & (0) & (0) & $(0)$ & $(10)$ \\
\hline Thyroid gland & (10) & $(10)$ & $(10)$ & $(10)$ & (10) & $(10)$ \\
\hline $\begin{array}{l}\text { Infiltration cellular, } \\
\text { mononuclear cell }\end{array}$ & - & - & - & - & - & $1(10 \%)$ \\
\hline \multicolumn{7}{|l|}{ General Body System } \\
\hline None & - & - & - & - & - & - \\
\hline \multicolumn{7}{|l|}{ Genital System } \\
\hline Clitoral gland & (10) & $(0)$ & (0) & (0) & $(0)$ & $(10)$ \\
\hline Ovary & $(10)$ & $(0)$ & (0) & (1) & $(0)$ & (10) \\
\hline Left, cyst & - & - & - & $1(100 \%)$ & - & - \\
\hline Left, inflammation & - & - & - & $1(100 \%)$ & - & - \\
\hline Uterus & $(10)$ & $(0)$ & $(0)$ & $(0)$ & $(0)$ & $(10)$ \\
\hline \multicolumn{7}{|l|}{ Hematopoietic System } \\
\hline Bone marrow & $(10)$ & (0) & $(0)$ & $(0)$ & $(0)$ & $(10)$ \\
\hline $\begin{array}{l}\text { Infiltration, cellular, } \\
\text { histiocyte }\end{array}$ & - & - & - & - & - & $1(10 \%)$ \\
\hline Lymph node, mandibular & $(10)$ & (0) & (0) & (0) & $(0)$ & $(10)$ \\
\hline Lymph node, mesenteric & $(10)$ & $(0)$ & $(0)$ & $(0)$ & $(0)$ & $(10)$ \\
\hline Inflammation, histiocytic & - & - & - & - & - & $5(50 \%)$ \\
\hline Spleen & $(10)$ & (0) & (0) & (0) & $(0)$ & $(10)$ \\
\hline Thymus & $(10)$ & $(0)$ & $(0)$ & $(0)$ & $(0)$ & $(10)$ \\
\hline \multicolumn{7}{|l|}{ Integumentary System } \\
\hline Mammary gland & $(10)$ & (0) & (0) & (0) & $(0)$ & $(10)$ \\
\hline Skin & $(10)$ & $(0)$ & $(0)$ & $(0)$ & $(0)$ & $(10)$ \\
\hline \multicolumn{7}{|l|}{ Musculoskeletal System } \\
\hline Bone & $(10)$ & $(0)$ & $(0)$ & $(0)$ & $(0)$ & $(10)$ \\
\hline \multicolumn{7}{|l|}{ Nervous System } \\
\hline Brain & $(10)$ & $(0)$ & $(0)$ & $(0)$ & $(0)$ & $(10)$ \\
\hline
\end{tabular}




\begin{tabular}{|c|c|c|c|c|c|c|}
\hline & $\begin{array}{l}\text { Vehicle } \\
\text { Control }\end{array}$ & $2 \mathrm{mg} / \mathrm{kg}$ & $4 \mathrm{mg} / \mathrm{kg}$ & $8 \mathrm{mg} / \mathrm{kg}$ & $16 \mathrm{mg} / \mathrm{kg}$ & $32 \mathrm{mg} / \mathrm{kg}$ \\
\hline \multicolumn{7}{|l|}{ Respiratory System } \\
\hline Lung & $(10)$ & (10) & $(10)$ & (10) & $(10)$ & (10) \\
\hline $\begin{array}{l}\text { Infiltration cellular, } \\
\text { histiocyte }\end{array}$ & - & - & - & - & - & $1(10 \%)$ \\
\hline Inflammation, chronic active & $2(20 \%)$ & $2(20 \%)$ & $6(60 \%)$ & $3(30 \%)$ & $5(50 \%)$ & $6(60 \%)$ \\
\hline Nose & $(10)$ & $(0)$ & $(0)$ & $(0)$ & $(0)$ & $(10)$ \\
\hline Inflammation, chronic active & - & - & - & - & - & $2(20 \%)$ \\
\hline Trachea & (10) & $(0)$ & $(0)$ & (0) & $(0)$ & (10) \\
\hline $\begin{array}{l}\text { Infiltration cellular, } \\
\text { mononuclear cell }\end{array}$ & $3(30 \%)$ & - & - & - & - & $1(10 \%)$ \\
\hline \multicolumn{7}{|l|}{ Special Senses System } \\
\hline Eye & $(10)$ & $(0)$ & $(0)$ & $(0)$ & $(0)$ & (10) \\
\hline Harderian gland & $(10)$ & $(0)$ & $(0)$ & $(0)$ & $(0)$ & (10) \\
\hline $\begin{array}{l}\text { Infiltration cellular, } \\
\text { mononuclear cell }\end{array}$ & - & - & - & - & - & $2(20 \%)$ \\
\hline Inflammation, chronic active & $1(10 \%)$ & - & - & - & - & $3(30 \%)$ \\
\hline \multicolumn{7}{|l|}{ Urinary System } \\
\hline Kidney & (10) & (0) & (0) & (0) & (0) & $(10)$ \\
\hline Infiltration cellular, lipocyte & $1(10 \%)$ & - & - & - & - & - \\
\hline $\begin{array}{l}\text { Infiltration cellular, } \\
\text { mononuclear cell }\end{array}$ & $1(10 \%)$ & - & - & - & - & - \\
\hline Mineralization & $7(70 \%)$ & - & - & - & - & $7(70 \%)$ \\
\hline Nephropathy & $3(30 \%)$ & - & - & - & - & - \\
\hline Urinary bladder & $(10)$ & (0) & $(0)$ & $(0)$ & $(0)$ & $(10)$ \\
\hline $\begin{array}{l}\text { Infiltration cellular, } \\
\text { mononuclear cell }\end{array}$ & $1(10 \%)$ & - & - & - & - & $1(10 \%)$ \\
\hline
\end{tabular}


Table A-3. Summary of the Incidence of Nonneoplastic Lesions in Male Mice in the Three-month Dermal Study of 5-Amino-o-cresol ${ }^{\mathrm{a}}$

\begin{tabular}{|c|c|c|c|c|c|c|}
\hline & $\begin{array}{l}\text { Vehicle } \\
\text { Control }\end{array}$ & $8 \mathrm{mg} / \mathrm{kg}$ & $16 \mathrm{mg} / \mathrm{kg}$ & $32 \mathrm{mg} / \mathrm{kg}$ & $64 \mathrm{mg} / \mathrm{kg}$ & $128 \mathrm{mg} / \mathrm{kg}$ \\
\hline \multicolumn{7}{|l|}{ Disposition Summary } \\
\hline Animals initially in study & 10 & 10 & 10 & 10 & 10 & 10 \\
\hline \multicolumn{7}{|l|}{ Survivors } \\
\hline Terminal kill & 10 & 10 & 10 & 10 & 10 & 10 \\
\hline $\begin{array}{l}\text { Animals examined } \\
\text { microscopically }\end{array}$ & 10 & 10 & 10 & 10 & 10 & 10 \\
\hline \multicolumn{7}{|l|}{ Alimentary System } \\
\hline Liver & (10) & (0) & $(0)$ & (0) & $(0)$ & (10) \\
\hline Inflammation & $7(70 \%)$ & - & - & - & - & $10(100 \%)$ \\
\hline Stomach, glandular & (10) & (0) & $(0)$ & $(0)$ & $(0)$ & $(10)$ \\
\hline Muscularis, hypertrophy & $1(10 \%)$ & - & - & - & - & - \\
\hline \multicolumn{7}{|l|}{ Cardiovascular System } \\
\hline \multicolumn{7}{|l|}{ None } \\
\hline \multicolumn{7}{|l|}{ Endocrine System } \\
\hline Adrenal cortex & (10) & (0) & (0) & (0) & $(0)$ & (10) \\
\hline Fibrosis & - & - & - & - & - & $1(10 \%)$ \\
\hline Hypertrophy & $1(10 \%)$ & - & - & - & - & - \\
\hline Subcapsular, hyperplasia & $2(20 \%)$ & - & - & - & - & - \\
\hline \multicolumn{7}{|l|}{ General Body System } \\
\hline None & - & - & - & - & - & - \\
\hline \multicolumn{7}{|l|}{ Genital System } \\
\hline Preputial gland & (10) & $(0)$ & $(0)$ & $(0)$ & $(0)$ & (10) \\
\hline Inflammation & - & - & - & - & - & $1(10 \%)$ \\
\hline \multicolumn{7}{|l|}{ Hematopoietic System } \\
\hline None & - & - & - & - & - & - \\
\hline \multicolumn{7}{|l|}{ Integumentary System } \\
\hline None & - & - & - & - & - & - \\
\hline \multicolumn{7}{|l|}{ Musculoskeletal System } \\
\hline None & - & - & - & - & - & - \\
\hline \multicolumn{7}{|l|}{ Nervous System } \\
\hline None & - & - & - & - & - & - \\
\hline
\end{tabular}


5-Amino-o-cresol, NTP TOX 89

\begin{tabular}{|c|c|c|c|c|c|c|}
\hline & $\begin{array}{l}\text { Vehicle } \\
\text { Control }\end{array}$ & $8 \mathrm{mg} / \mathrm{kg}$ & $16 \mathrm{mg} / \mathrm{kg}$ & $32 \mathrm{mg} / \mathrm{kg}$ & $64 \mathrm{mg} / \mathrm{kg}$ & $128 \mathrm{mg} / \mathrm{kg}$ \\
\hline \multicolumn{7}{|l|}{ Respiratory System } \\
\hline Lung & $(10)$ & $(10)$ & $(10)$ & $(10)$ & $(10)$ & (10) \\
\hline Bronchiole, hyperplasia & - & $2(20 \%)$ & $2(20 \%)$ & - & - & - \\
\hline \multicolumn{7}{|l|}{ Special Senses System } \\
\hline None & - & - & - & - & - & - \\
\hline \multicolumn{7}{|l|}{ Urinary System } \\
\hline Kidney & $(10)$ & $(10)$ & $(10)$ & (10) & (10) & $(10)$ \\
\hline Inflammation & $1(10 \%)$ & - & - & - & - & - \\
\hline Mineralization & $1(10 \%)$ & - & - & - & - & $1(10 \%)$ \\
\hline Nephropathy & $1(10 \%)$ & - & - & - & - & $3(30 \%)$ \\
\hline Renal tubule, nephropathy & - & - & - & - & - & $1(10 \%)$ \\
\hline Renal tubule, regeneration & - & - & - & - & - & $1(10 \%)$ \\
\hline
\end{tabular}

${ }^{a}$ Number of animals examined microscopically at the site and the number of animals with lesion. 
Table A-4. Summary of the Incidence of Neoplasms and Nonneoplastic Lesions in Female Mice in the Three-month Dermal Study of 5-Amino-o-cresol ${ }^{\mathrm{a}}$

\begin{tabular}{|c|c|c|c|c|c|c|}
\hline & $\begin{array}{l}\text { Vehicle } \\
\text { Control }\end{array}$ & $8 \mathrm{mg} / \mathrm{kg}$ & $16 \mathrm{mg} / \mathrm{kg}$ & $32 \mathrm{mg} / \mathrm{kg}$ & $64 \mathrm{mg} / \mathrm{kg}$ & $128 \mathrm{mg} / \mathrm{kg}$ \\
\hline \multicolumn{7}{|l|}{ Disposition Summary } \\
\hline Animals initially in study & 10 & 10 & 10 & 10 & 10 & 10 \\
\hline \multicolumn{7}{|l|}{ Early deaths } \\
\hline Natural death & - & - & - & 1 & - & - \\
\hline \multicolumn{7}{|l|}{ Survivors } \\
\hline Terminal kill & 10 & 10 & 10 & 9 & 10 & 10 \\
\hline $\begin{array}{l}\text { Animals examined } \\
\text { microscopically }\end{array}$ & 10 & 10 & 10 & 10 & 10 & 10 \\
\hline \multicolumn{7}{|l|}{ Alimentary System } \\
\hline Liver & $(10)$ & $(0)$ & $(0)$ & (1) & $(0)$ & $(10)$ \\
\hline Inflammation & $10(100 \%)$ & - & - & - & - & $8(80 \%)$ \\
\hline Stomach, glandular & (10) & $(0)$ & $(0)$ & (1) & $(0)$ & $(10)$ \\
\hline Cyst & - & - & - & - & - & $1(10 \%)$ \\
\hline \multicolumn{7}{|l|}{ Cardiovascular System } \\
\hline Heart & $(10)$ & $(0)$ & $(0)$ & (1) & $(0)$ & $(10)$ \\
\hline Cardiomyopathy & $2(20 \%)$ & - & - & - & - & - \\
\hline $\begin{array}{l}\text { Epicardium, hyperplasia, } \\
\text { focal }\end{array}$ & - & - & - & - & - & $1(10 \%)$ \\
\hline \multicolumn{7}{|l|}{ Endocrine System } \\
\hline Adrenal cortex & $(10)$ & $(0)$ & $(0)$ & (1) & $(0)$ & $(10)$ \\
\hline Subcapsular, hyperplasia & $10(100 \%)$ & - & - & $1(100 \%)$ & - & $9(90 \%)$ \\
\hline \multicolumn{7}{|l|}{ General Body System } \\
\hline None & - & - & - & - & - & - \\
\hline \multicolumn{7}{|l|}{ Genital System } \\
\hline Ovary & $(10)$ & $(0)$ & $(0)$ & (1) & $(0)$ & $(10)$ \\
\hline Left, teratoma benign & - & - & - & $1(100 \%)$ & - & - \\
\hline \multicolumn{7}{|l|}{ Hematopoietic System } \\
\hline None & - & - & - & - & - & - \\
\hline \multicolumn{7}{|l|}{ Integumentary System } \\
\hline None & - & - & - & - & - & - \\
\hline \multicolumn{7}{|l|}{ Musculoskeletal System } \\
\hline None & - & - & - & - & - & - \\
\hline \multicolumn{7}{|l|}{ Nervous System } \\
\hline None & - & - & - & - & - & - \\
\hline
\end{tabular}


5-Amino-o-cresol, NTP TOX 89

\begin{tabular}{|c|c|c|c|c|c|c|}
\hline & $\begin{array}{l}\text { Vehicle } \\
\text { Control }\end{array}$ & $8 \mathrm{mg} / \mathrm{kg}$ & $16 \mathrm{mg} / \mathrm{kg}$ & $32 \mathrm{mg} / \mathrm{kg}$ & $64 \mathrm{mg} / \mathrm{kg}$ & $128 \mathrm{mg} / \mathrm{kg}$ \\
\hline \multicolumn{7}{|l|}{ Respiratory System } \\
\hline Lung & $(10)$ & $(10)$ & $(10)$ & $(10)$ & $(10)$ & $(10)$ \\
\hline Inflammation, chronic & - & - & - & - & - & $1(10 \%)$ \\
\hline Inflammation, chronic active & - & - & - & $1(10 \%)$ & - & - \\
\hline $\begin{array}{l}\text { Alveolar epithelium, } \\
\text { hyperplasia }\end{array}$ & - & - & - & - & - & $1(10 \%)$ \\
\hline $\begin{array}{l}\text { Alveolar epithelium, } \\
\text { bronchiole, metaplasia }\end{array}$ & - & - & - & - & - & $1(10 \%)$ \\
\hline \multicolumn{7}{|l|}{ Special Senses System } \\
\hline None & - & - & - & - & - & - \\
\hline \multicolumn{7}{|l|}{ Urinary System } \\
\hline Kidney & $(10)$ & $(10)$ & $(10)$ & $(10)$ & (10) & (10) \\
\hline Inflammation & $1(10 \%)$ & - & - & - & - & - \\
\hline Mineralization & $2(20 \%)$ & - & - & - & - & $2(20 \%)$ \\
\hline Nephropathy & $2(20 \%)$ & - & - & - & - & $2(20 \%)$ \\
\hline
\end{tabular}

${ }^{a}$ Number of animals examined microscopically at the site and the number of animals with lesion. 


\section{Appendix B. Clinical Pathology Results}

\section{Tables}

Table B-1. Hematology and Clinical Chemistry Data for Rats in the Three-month Dermal Study of 5-Amino- $\mathrm{O}$-cresol...........................................................................

Table B-2. Hematology Data for Mice in the Three-month Dermal Study of 5-Amino-ocresol . 
Table B-1. Hematology and Clinical Chemistry Data for Rats in the Three-month Dermal Study of 5-Amino-o-cresol ${ }^{\mathrm{a}}$

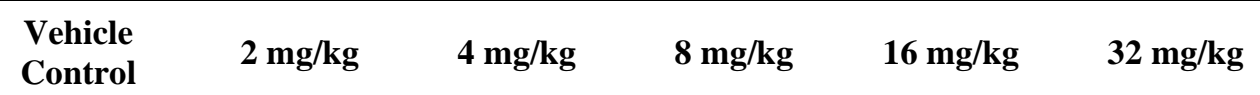

\section{Male}

\section{Hematology}

n

\begin{tabular}{lcccccc} 
Day 4 & 9 & 10 & 10 & 9 & 9 & 10 \\
Day 23 & 10 & 10 & 10 & 10 & 10 & 10 \\
Week 14 & 9 & 9 & 10 & 9 & 8 & 9 \\
\hline
\end{tabular}

Hematocrit (\%)

Day 4

Day 23

$43.4 \pm 0.4$

$43.7 \pm 0.4$

$43.2 \pm 0.5$

$43.7 \pm 0.7$

$43.6 \pm 0.6$

$42.9 \pm 0.3$

Week 14

$43.4 \pm 0.5$

$43.5 \pm 0.3$

$42.4 \pm 0.4$

$42.5 \pm 0.3$

$43.5 \pm 0.7$

$41.8 \pm 0.5$

Hemoglobin (g/dL)

Day 4

$46.5 \pm 0.5$

$47.2 \pm 0.3$

$46.4 \pm 0.5$

$45.8 \pm 0.3$

$47.7 \pm 0.5$

$46.1 \pm 0.5$

Day 23

$13.8 \pm 0.2$

$13.7 \pm 0.1$

$13.6 \pm 0.2$

$13.9 \pm 0.2$

$13.7 \pm 0.2$

$13.6 \pm 0.1$

Week 14

$14.1 \pm 0.2$

$14.1 \pm 0.1$

$13.8 \pm 0.1$

$14.1 \pm 0.2$

$14.2 \pm 0.2$

$13.7 \pm 0.2$

Erythrocytes $\left(10^{6} / \mu \mathrm{L}\right)$

Day 4

$15.5 \pm 0.2$

$15.6 \pm 0.1$

$15.4 \pm 0.1$

$15.3 \pm 0.1$

$15.9 \pm 0.1$

$15.4 \pm 0.2$

Day 23

Week 14

$7.17 \pm 0.06$

$7.26 \pm 0.06$

$7.19 \pm 0.10$

$7.27 \pm 0.11$

$7.22 \pm 0.11$

$7.58 \pm 0.05$

$7.76 \pm 0.11$

$9.46 \pm 0.06$

$9.68 \pm 0.07$

$9.46 \pm 0.09$

$9.46 \pm 0.09$

$9.52 \pm 0.06$

Reticulocytes $\left(10^{3} / \mu \mathrm{L}\right)$

Day 4

$$
651 \pm 18
$$

$640 \pm 19$

$290 \pm 9$

$653 \pm 11$

$665 \pm 7$

$686 \pm 15$

$307 \pm 13$

$298 \pm 8$

$207 \pm 6$

$7.15 \pm 0.06$

$7.48 \pm 0.11$

$9.48 \pm 0.09$

Week 14

$$
208 \pm 8 \quad 192 \pm 9
$$

$194 \pm 6$

$188 \pm 5$

Mean cell volume (fL)

Day 4

Day 23

Week 14

$60.6 \pm 0.2$

$60.2 \pm 0.2$

$60.1 \pm 0.2$

$60.2 \pm 0.3$

$60.3 \pm 0.2$

$60.0 \pm 0.3$

$55.7 \pm 0.2$

$56.0 \pm 0.3$

$56.0 \pm 0.3$

$55.8 \pm 0.2$

$49.1 \pm 0.3$

$48.4 \pm 0.3$

$49.2 \pm 0.3$

$48.6 \pm 0.2$

Mean cell hemoglobin (pg)

$\begin{array}{lllllll}\text { Day } 4 & 19.2 \pm 0.1 & 18.9 \pm 0.1 & 19.0 \pm 0.1 & 19.1 \pm 0.2 & 19.0 \pm 0.1 & 19.1 \pm 0.1 \\ \text { Day 23 } & 18.3 \pm 0.1 & 18.3 \pm 0.1 & 18.2 \pm 0.1 & 18.6 \pm 0.1 & 18.3 \pm 0.1 & 18.3 \pm 0.1 \\ \text { Week 14 } & 16.4 \pm 0.1 & 16.4 \pm 0.1 & 16.3 \pm 0.1 & 16.1 \pm 0.1 & 16.4 \pm 0.1 & 16.2 \pm 0.1\end{array}$

Mean cell hemoglobin concentration $(\mathrm{g} / \mathrm{dL})$

\begin{tabular}{lllllll} 
Day 4 & $31.7 \pm 0.2$ & $31.4 \pm 0.2$ & $31.5 \pm 0.1$ & $31.8 \pm 0.1$ & $31.5 \pm 0.2$ & $31.8 \pm 0.2$ \\
Day 23 & $32.5 \pm 0.2$ & $32.4 \pm 0.2$ & $32.7 \pm 0.2$ & $33.1 \pm 0.2$ & $32.7 \pm 0.3$ & $32.7 \pm 0.2$ \\
Week 14 & $33.4 \pm 0.2$ & $33.1 \pm 0.2$ & $33.2 \pm 0.2$ & $33.3 \pm 0.1$ & $33.3 \pm 0.2$ & $33.3 \pm 0.2$ \\
\hline
\end{tabular}


5-Amino-o-cresol, NTP TOX 89

\begin{tabular}{|c|c|c|c|c|c|c|}
\hline & $\begin{array}{l}\text { Vehicle } \\
\text { Control }\end{array}$ & $2 \mathrm{mg} / \mathrm{kg}$ & $4 \mathrm{mg} / \mathrm{kg}$ & $8 \mathrm{mg} / \mathrm{kg}$ & $16 \mathrm{mg} / \mathrm{kg}$ & $32 \mathrm{mg} / \mathrm{kg}$ \\
\hline \multicolumn{7}{|c|}{ Platelets $\left(10^{3} / \mu \mathrm{L}\right)$} \\
\hline Day 4 & $1,237 \pm 34$ & $1,282 \pm 44$ & $1,236 \pm 33$ & $1,322 \pm 41$ & $1,290 \pm 31$ & $1,242 \pm 47$ \\
\hline Day 23 & $1,027 \pm 18$ & $1,068 \pm 29$ & $1,069 \pm 18$ & $1,074 \pm 22$ & $998 \pm 46$ & $1,069 \pm 34$ \\
\hline Week 14 & $718 \pm 22$ & $701 \pm 14$ & $711 \pm 17$ & $715 \pm 26$ & $672 \pm 23$ & $712 \pm 11$ \\
\hline \multicolumn{7}{|c|}{ Leukocytes $\left(10^{3} / \mu \mathrm{L}\right)$} \\
\hline Day 4 & $7.19 \pm 0.36$ & $7.54 \pm 0.39$ & $6.83 \pm 0.47$ & $6.84 \pm 0.70$ & $7.07 \pm 0.29$ & $7.78 \pm 0.41$ \\
\hline Day 23 & $8.26 \pm 0.92$ & $8.09 \pm 0.67$ & $7.39 \pm 0.65$ & $7.12 \pm 0.66$ & $7.47 \pm 0.71$ & $6.93 \pm 0.88$ \\
\hline Week 14 & $7.77 \pm 0.24$ & $7.34 \pm 0.15$ & $7.45 \pm 0.53$ & $7.41 \pm 0.30$ & $7.21 \pm 0.40$ & $7.82 \pm 0.35$ \\
\hline \multicolumn{7}{|c|}{ Segmented neutrophils $\left(10^{3} / \mu \mathrm{L}\right)$} \\
\hline Day 4 & $1.53 \pm 0.11$ & $1.59 \pm 0.09$ & $1.53 \pm 0.14$ & $1.53 \pm 0.20$ & $1.46 \pm 0.10$ & $1.70 \pm 0.12$ \\
\hline Day 23 & $1.52 \pm 0.20$ & $1.56 \pm 0.21$ & $1.53 \pm 0.18$ & $1.29 \pm 0.11$ & $1.41 \pm 0.13$ & $1.68 \pm 0.25$ \\
\hline Week 14 & $1.29 \pm 0.10$ & $1.35 \pm 0.09$ & $1.42 \pm 0.12$ & $1.22 \pm 0.08$ & $1.27 \pm 0.11$ & $1.43 \pm 0.17$ \\
\hline \multicolumn{7}{|c|}{ Lymphocytes $\left(10^{3} / \mu \mathrm{L}\right)$} \\
\hline Day 4 & $5.26 \pm 0.29$ & $5.53 \pm 0.36$ & $4.92 \pm 0.33$ & $4.98 \pm 0.46$ & $5.20 \pm 0.24$ & $5.65 \pm 0.29$ \\
\hline Day 23 & $6.36 \pm 0.70$ & $6.19 \pm 0.47$ & $5.52 \pm 0.46$ & $5.54 \pm 0.57$ & $5.76 \pm 0.59$ & $4.93 \pm 0.60$ \\
\hline Week 14 & $6.21 \pm 0.17$ & $5.71 \pm 0.17$ & $5.76 \pm 0.42$ & $5.88 \pm 0.25$ & $5.62 \pm 0.36$ & $6.09 \pm 0.24$ \\
\hline \multicolumn{7}{|c|}{ Monocytes $\left(10^{3} / \mu \mathrm{L}\right)$} \\
\hline Day 4 & $0.26 \pm 0.02$ & $0.26 \pm 0.02$ & $0.25 \pm 0.03$ & $0.22 \pm 0.03$ & $0.25 \pm 0.02$ & $0.28 \pm 0.02$ \\
\hline Day 23 & $0.23 \pm 0.04$ & $0.21 \pm 0.03$ & $0.19 \pm 0.03$ & $0.17 \pm 0.02$ & $0.16 \pm 0.02$ & $0.19 \pm 0.03$ \\
\hline Week 14 & $0.17 \pm 0.01$ & $0.16 \pm 0.01$ & $0.18 \pm 0.02$ & $0.19 \pm 0.02$ & $0.20 \pm 0.03$ & $0.18 \pm 0.02$ \\
\hline \multicolumn{7}{|c|}{ Basophils $\left(10^{3} / \mu \mathrm{L}\right)$} \\
\hline Day 4 & $0.070 \pm 0.016$ & $0.082 \pm 0.012$ & $0.078 \pm 0.012$ & $0.064 \pm 0.015$ & $0.077 \pm 0.007$ & $0.085 \pm 0.011$ \\
\hline Day 23 & $0.068 \pm 0.015$ & $0.053 \pm 0.005$ & $0.049 \pm 0.007$ & $0.050 \pm 0.009$ & $0.054 \pm 0.011$ & $0.045 \pm 0.008$ \\
\hline Week 14 & $0.026 \pm 0.002$ & $0.023 \pm 0.002$ & $0.023 \pm 0.003$ & $0.024 \pm 0.003$ & $0.023 \pm 0.004$ & $0.022 \pm 0.004$ \\
\hline \multicolumn{7}{|c|}{ Eosinophils $\left(10^{3} / \mu \mathrm{L}\right)$} \\
\hline Day 4 & $0.07 \pm 0.01$ & $0.08 \pm 0.02$ & $0.06 \pm 0.01$ & $0.04 \pm 0.01$ & $0.08 \pm 0.02$ & $0.07 \pm 0.02$ \\
\hline Day 23 & $0.08 \pm 0.01$ & $0.08 \pm 0.01$ & $0.09 \pm 0.01$ & $0.07 \pm 0.01$ & $0.08 \pm 0.01$ & $0.08 \pm 0.01$ \\
\hline Week 14 & $0.08 \pm 0.01$ & $0.10 \pm 0.01$ & $0.07 \pm 0.01$ & $0.10 \pm 0.01$ & $0.09 \pm 0.01$ & $0.09 \pm 0.01$ \\
\hline
\end{tabular}

\section{Clinical Chemistry}

\begin{tabular}{lcccccc}
$\mathbf{n}$ & 10 & 10 & 10 & 10 & 10 & 10 \\
\hline Urea nitrogen (mg/dL) & & & & & & \\
$\quad$ Day 4 & $10.5 \pm 0.4$ & $9.7 \pm 0.4$ & $10.2 \pm 0.4$ & $9.6 \pm 0.5$ & $10.5 \pm 0.3$ & $9.8 \pm 0.6$ \\
Day 23 & $12.1 \pm 0.3$ & $10.9 \pm 0.3$ & $10.9 \pm 0.3$ & $11.9 \pm 0.5$ & $9.9 \pm 0.3^{* *}$ & $10.6 \pm 0.3^{* *}$ \\
Week 14 & $15.4 \pm 0.5$ & $14.9 \pm 0.3$ & $14.6 \pm 0.4$ & $14.9 \pm 0.5$ & $14.7 \pm 0.5$ & $15.8 \pm 0.4$ \\
\hline
\end{tabular}


5-Amino-o-cresol, NTP TOX 89

\begin{tabular}{|c|c|c|c|c|c|c|}
\hline & $\begin{array}{l}\text { Vehicle } \\
\text { Control }\end{array}$ & $2 \mathrm{mg} / \mathrm{kg}$ & $4 \mathrm{mg} / \mathrm{kg}$ & $8 \mathrm{mg} / \mathrm{kg}$ & $16 \mathrm{mg} / \mathrm{kg}$ & $32 \mathrm{mg} / \mathrm{kg}$ \\
\hline \multicolumn{7}{|c|}{ Creatinine (mg/dL) } \\
\hline Day 4 & $0.49 \pm 0.01$ & $0.47 \pm 0.02$ & $0.49 \pm 0.01$ & $0.49 \pm 0.01$ & $0.48 \pm 0.01$ & $0.50 \pm 0.00$ \\
\hline Day 23 & $0.49 \pm 0.01$ & $0.49 \pm 0.01$ & $0.49 \pm 0.01$ & $0.49 \pm 0.01$ & $0.46 \pm 0.02$ & $0.49 \pm 0.01$ \\
\hline Week 14 & $0.69 \pm 0.02$ & $0.70 \pm 0.02$ & $0.68 \pm 0.02$ & $0.68 \pm 0.01$ & $0.72 \pm 0.02$ & $0.73 \pm 0.04$ \\
\hline \multicolumn{7}{|c|}{ Glucose (mg/dL) } \\
\hline Day 4 & $132 \pm 2$ & $135 \pm 3$ & $135 \pm 2$ & $138 \pm 4$ & $137 \pm 3$ & $133 \pm 3$ \\
\hline Day 23 & $142 \pm 3$ & $140 \pm 3$ & $144 \pm 2$ & $140 \pm 2$ & $144 \pm 2$ & $145 \pm 2$ \\
\hline Week 14 & $132 \pm 3$ & $139 \pm 4$ & $128 \pm 4$ & $133 \pm 4$ & $135 \pm 7$ & $135 \pm 4$ \\
\hline \multicolumn{7}{|c|}{ Total protein $(\mathrm{g} / \mathrm{dL})$} \\
\hline Day 4 & $5.5 \pm 0.1$ & $5.4 \pm 0.0$ & $5.5 \pm 0.1$ & $5.5 \pm 0.1$ & $5.5 \pm 0.1$ & $5.6 \pm 0.1$ \\
\hline Day 23 & $5.9 \pm 0.1$ & $5.9 \pm 0.1$ & $5.9 \pm 0.0$ & $5.9 \pm 0.1$ & $5.9 \pm 0.1$ & $5.8 \pm 0.1$ \\
\hline Week 14 & $7.3 \pm 0.1$ & $7.2 \pm 0.0$ & $7.3 \pm 0.0$ & $7.4 \pm 0.0$ & $7.3 \pm 0.1$ & $7.3 \pm 0.1$ \\
\hline \multicolumn{7}{|c|}{ Albumin (g/dL) } \\
\hline Day 4 & $4.0 \pm 0.0$ & $4.0 \pm 0.0$ & $4.0 \pm 0.0$ & $4.0 \pm 0.0$ & $4.0 \pm 0.0$ & $4.1 \pm 0.0$ \\
\hline Day 23 & $4.1 \pm 0.0$ & $4.1 \pm 0.0$ & $4.0 \pm 0.0$ & $4.1 \pm 0.0$ & $4.1 \pm 0.0$ & $4.0 \pm 0.0$ \\
\hline Week 14 & $4.6 \pm 0.0$ & $4.5 \pm 0.0$ & $4.6 \pm 0.0$ & $4.6 \pm 0.0$ & $4.6 \pm 0.0$ & $4.5 \pm 0.0$ \\
\hline \multicolumn{7}{|c|}{ Alanine aminotransferase (IU/L) } \\
\hline Day 4 & $66 \pm 1$ & $64 \pm 1$ & $68 \pm 2$ & $65 \pm 1$ & $65 \pm 1$ & $66 \pm 2$ \\
\hline Day 23 & $43 \pm 1$ & $44 \pm 1$ & $45 \pm 1$ & $45 \pm 2$ & $45 \pm 1$ & $43 \pm 1$ \\
\hline Week 14 & $76 \pm 6$ & $79 \pm 4$ & $76 \pm 3$ & $76 \pm 3$ & $75 \pm 2$ & $77 \pm 4$ \\
\hline \multicolumn{7}{|c|}{ Alkaline phosphatase (IU/L) } \\
\hline Day 4 & $660 \pm 14$ & $661 \pm 17$ & $645 \pm 14$ & $683 \pm 15$ & $650 \pm 12$ & $671 \pm 13$ \\
\hline Day 23 & $489 \pm 10$ & $487 \pm 8$ & $475 \pm 11$ & $482 \pm 8$ & $507 \pm 12$ & $489 \pm 9$ \\
\hline Week 14 & $250 \pm 6$ & $232 \pm 3$ & $231 \pm 3$ & $230 \pm 6$ & $234 \pm 4$ & $232 \pm 6$ \\
\hline \multicolumn{7}{|c|}{ Creatine kinase (IU/L) } \\
\hline Day 4 & $470 \pm 57$ & $561 \pm 101$ & $681 \pm 99$ & $470 \pm 60$ & $501 \pm 81$ & $510 \pm 94$ \\
\hline Day 23 & $334 \pm 44$ & $342 \pm 41$ & $356 \pm 39$ & $375 \pm 37$ & $248 \pm 24$ & $365 \pm 40$ \\
\hline Week 14 & $409 \pm 80$ & $625 \pm 90$ & $272 \pm 37$ & $336 \pm 53$ & $353 \pm 33$ & $338 \pm 54$ \\
\hline \multicolumn{7}{|c|}{ Sorbitol dehydrogenase (IU/L) } \\
\hline Day 4 & $13 \pm 1$ & $12 \pm 1$ & $13 \pm 0$ & $13 \pm 1$ & $12 \pm 1$ & $12 \pm 0$ \\
\hline Day 23 & $16 \pm 1$ & $15 \pm 1$ & $15 \pm 1$ & $14 \pm 1$ & $14 \pm 1$ & $14 \pm 1$ \\
\hline Week 14 & $22 \pm 1$ & $23 \pm 2$ & $24 \pm 1$ & $24 \pm 1$ & $24 \pm 1$ & $23 \pm 1$ \\
\hline
\end{tabular}


5-Amino-o-cresol, NTP TOX 89

\begin{tabular}{|c|c|c|c|c|c|c|}
\hline & $\begin{array}{l}\text { Vehicle } \\
\text { Control }\end{array}$ & $2 \mathrm{mg} / \mathrm{kg}$ & $4 \mathrm{mg} / \mathrm{kg}$ & $8 \mathrm{mg} / \mathrm{kg}$ & $16 \mathrm{mg} / \mathrm{kg}$ & $32 \mathrm{mg} / \mathrm{kg}$ \\
\hline \multicolumn{7}{|c|}{ Bile acids $(\mu \mathrm{mol} / \mathrm{L})$} \\
\hline Day 4 & $27.8 \pm 4.3$ & $28.4 \pm 4.5$ & $27.2 \pm 4.4$ & $25.4 \pm 4.2$ & $24.0 \pm 3.2$ & $32.2 \pm 4.7$ \\
\hline Day 23 & $17.2 \pm 2.9$ & $18.2 \pm 2.9$ & $19.9 \pm 2.0$ & $15.7 \pm 2.0$ & $16.2 \pm 2.4$ & $15.6 \pm 1.1$ \\
\hline Week 14 & $9.8 \pm 2.2$ & $7.2 \pm 1.3$ & $5.2 \pm 0.8$ & $5.1 \pm 0.6$ & $7.9 \pm 2.1$ & $7.8 \pm 1.4$ \\
\hline \multicolumn{7}{|c|}{ Total thyroxine $(\mathrm{mmol} / \mathrm{L})$} \\
\hline Week 14 & $5.89 \pm 0.24$ & $5.98 \pm 0.25$ & $5.89 \pm 0.15$ & $5.76 \pm 0.20$ & $5.79 \pm 0.17$ & $5.77 \pm 0.16$ \\
\hline
\end{tabular}

\section{Female}

\section{Hematology}

n

\begin{tabular}{|c|c|c|c|c|c|c|}
\hline Day 4 & 10 & 9 & 10 & 10 & 9 & 10 \\
\hline Day 23 & 9 & 10 & 9 & 10 & 10 & 10 \\
\hline Week 14 & 10 & 9 & 10 & 10 & 8 & 10 \\
\hline \multicolumn{7}{|c|}{ Hematocrit (\%) } \\
\hline Day 4 & $42.6 \pm 0.6$ & $45.9 \pm 1.2^{*}$ & $44.4 \pm 0.8$ & $43.5 \pm 0.6$ & $43.6 \pm 0.5$ & $44.3 \pm 0.6$ \\
\hline Day 23 & $42.4 \pm 0.2$ & $42.9 \pm 0.7$ & $43.8 \pm 0.5$ & $42.9 \pm 0.4$ & $41.9 \pm 0.5$ & $42.5 \pm 0.5$ \\
\hline Week 14 & $45.0 \pm 0.5$ & $44.8 \pm 0.5$ & $45.0 \pm 0.5$ & $44.9 \pm 0.3$ & $45.1 \pm 0.5$ & $44.9 \pm 0.3$ \\
\hline \multicolumn{7}{|c|}{ Hemoglobin (g/dL) } \\
\hline Day 4 & $13.7 \pm 0.2$ & $14.7 \pm 0.3$ & $14.3 \pm 0.3$ & $14.0 \pm 0.2$ & $14.0 \pm 0.2$ & $14.3 \pm 0.2$ \\
\hline Day 23 & $14.2 \pm 0.1$ & $14.3 \pm 0.2$ & $14.5 \pm 0.1$ & $14.3 \pm 0.1$ & $13.9 \pm 0.1$ & $14.2 \pm 0.1$ \\
\hline Week 14 & $15.4 \pm 0.1$ & $15.3 \pm 0.1$ & $15.3 \pm 0.2$ & $15.4 \pm 0.1$ & $15.5 \pm 0.2$ & $15.4 \pm 0.1$ \\
\hline \multicolumn{7}{|c|}{ Erythrocytes $\left(10^{6} / \mu \mathrm{L}\right)$} \\
\hline Day 4 & $7.20 \pm 0.09$ & $7.77 \pm 0.17 * *$ & $7.53 \pm 0.14$ & $7.41 \pm 0.07$ & $7.45 \pm 0.07$ & $7.43 \pm 0.09$ \\
\hline Day 23 & $7.76 \pm 0.04$ & $7.87 \pm 0.11$ & $8.00 \pm 0.09$ & $7.89 \pm 0.07$ & $7.75 \pm 0.09$ & $7.75 \pm 0.08$ \\
\hline Week 14 & $8.66 \pm 0.08$ & $8.66 \pm 0.08$ & $8.60 \pm 0.10$ & $8.62 \pm 0.06$ & $8.65 \pm 0.09$ & $8.61 \pm 0.06$ \\
\hline \multicolumn{7}{|c|}{ Reticulocytes $\left(10^{3} / \mu \mathrm{L}\right)$} \\
\hline Day 4 & $487 \pm 19$ & $479 \pm 34$ & $441 \pm 10$ & $479 \pm 20$ & $457 \pm 20$ & $497 \pm 17$ \\
\hline Day 23 & $168 \pm 4$ & $179 \pm 4$ & $169 \pm 8$ & $176 \pm 11$ & $169 \pm 8$ & $181 \pm 7$ \\
\hline Week 14 & $184 \pm 6$ & $178 \pm 11$ & $191 \pm 10$ & $189 \pm 11$ & $185 \pm 9$ & $179 \pm 7$ \\
\hline \multicolumn{7}{|c|}{ Mean cell volume (fL) } \\
\hline Day 4 & $59.2 \pm 0.3$ & $59.0 \pm 0.3$ & $59.0 \pm 0.3$ & $58.8 \pm 0.4$ & $58.5 \pm 0.4$ & $59.7 \pm 0.3$ \\
\hline Day 23 & $54.6 \pm 0.2$ & $54.5 \pm 0.3$ & $54.8 \pm 0.1$ & $54.4 \pm 0.2$ & $54.0 \pm 0.2$ & $54.8 \pm 0.1$ \\
\hline Week 14 & $52.0 \pm 0.3$ & $51.7 \pm 0.2$ & $52.3 \pm 0.2$ & $52.1 \pm 0.1$ & $52.1 \pm 0.2$ & $52.1 \pm 0.2$ \\
\hline
\end{tabular}


5-Amino-o-cresol, NTP TOX 89

\begin{tabular}{|c|c|c|c|c|c|c|}
\hline & $\begin{array}{l}\text { Vehicle } \\
\text { Control }\end{array}$ & $2 \mathrm{mg} / \mathrm{kg}$ & $4 \mathrm{mg} / \mathrm{kg}$ & $8 \mathrm{mg} / \mathrm{kg}$ & $16 \mathrm{mg} / \mathrm{kg}$ & $32 \mathrm{mg} / \mathrm{kg}$ \\
\hline \multicolumn{7}{|c|}{ Mean cell hemoglobin (pg) } \\
\hline Day 4 & $19.0 \pm 0.1$ & $18.9 \pm 0.1$ & $19.0 \pm 0.1$ & $18.9 \pm 0.2$ & $18.8 \pm 0.1$ & $19.2 \pm 0.1$ \\
\hline Day 23 & $18.4 \pm 0.1$ & $18.2 \pm 0.1$ & $18.1 \pm 0.1$ & $18.2 \pm 0.1$ & $18.0 \pm 0.1$ & $18.3 \pm 0.1$ \\
\hline Week 14 & $17.8 \pm 0.1$ & $17.7 \pm 0.1$ & $17.9 \pm 0.1$ & $17.9 \pm 0.1$ & $17.9 \pm 0.1$ & $17.8 \pm 0.1$ \\
\hline \multicolumn{7}{|c|}{ Mean cell hemoglobin concentration $(\mathrm{g} / \mathrm{dL})$} \\
\hline Day 4 & $32.2 \pm 0.1$ & $32.0 \pm 0.2$ & $32.1 \pm 0.1$ & $32.1 \pm 0.1$ & $32.1 \pm 0.2$ & $32.2 \pm 0.2$ \\
\hline Day 23 & $33.6 \pm 0.1$ & $33.3 \pm 0.1$ & $33.1 \pm 0.2$ & $33.4 \pm 0.1$ & $33.4 \pm 0.2$ & $33.4 \pm 0.2$ \\
\hline Week 14 & $34.3 \pm 0.1$ & $34.1 \pm 0.1$ & $34.1 \pm 0.1$ & $34.4 \pm 0.1$ & $34.3 \pm 0.1$ & $34.3 \pm 0.1$ \\
\hline \multicolumn{7}{|c|}{ Platelets $\left(10^{3} / \mu \mathrm{L}\right)$} \\
\hline Day 4 & $1,093 \pm 23$ & $1,031 \pm 34$ & $1,097 \pm 48$ & $1,029 \pm 30$ & $1,143 \pm 39$ & $1,064 \pm 58$ \\
\hline Day 23 & $960 \pm 41$ & $966 \pm 26$ & $855 \pm 55$ & $902 \pm 50$ & $916 \pm 29$ & $951 \pm 45$ \\
\hline Week 14 & $735 \pm 19$ & $717 \pm 24$ & $741 \pm 22$ & $739 \pm 23$ & $708 \pm 36$ & $707 \pm 13$ \\
\hline \multicolumn{7}{|c|}{ Leukocytes $\left(10^{3} / \mu \mathrm{L}\right)$} \\
\hline Day 4 & $6.92 \pm 0.49$ & $7.27 \pm 0.85$ & $7.21 \pm 0.62$ & $7.31 \pm 0.44$ & $7.01 \pm 0.50$ & $7.15 \pm 0.43$ \\
\hline Day 23 & $6.18 \pm 0.60$ & $6.76 \pm 0.66$ & $6.48 \pm 0.59$ & $7.61 \pm 0.69$ & $5.49 \pm 0.64$ & $6.79 \pm 0.64$ \\
\hline Week 14 & $5.45 \pm 0.46$ & $5.80 \pm 0.45$ & $5.50 \pm 0.55$ & $5.84 \pm 0.23$ & $5.05 \pm 0.44$ & $6.30 \pm 0.32$ \\
\hline \multicolumn{7}{|c|}{ Segmented neutrophils $\left(10^{3} / \mu \mathrm{L}\right)$} \\
\hline Day 4 & $1.20 \pm 0.09$ & $1.28 \pm 0.18$ & $1.43 \pm 0.16$ & $1.24 \pm 0.10$ & $1.18 \pm 0.10$ & $1.30 \pm 0.10$ \\
\hline Day 23 & $1.08 \pm 0.12$ & $1.38 \pm 0.16$ & $1.03 \pm 0.15$ & $1.17 \pm 0.16$ & $0.99 \pm 0.17$ & $1.34 \pm 0.13$ \\
\hline Week 14 & $1.03 \pm 0.12$ & $1.04 \pm 0.09$ & $0.99 \pm 0.08$ & $1.16 \pm 0.09$ & $1.20 \pm 0.19$ & $1.24 \pm 0.10$ \\
\hline \multicolumn{7}{|c|}{ Lymphocytes $\left(10^{3} / \mu \mathrm{L}\right)$} \\
\hline Day 4 & $5.38 \pm 0.41$ & $5.63 \pm 0.64$ & $5.40 \pm 0.44$ & $5.68 \pm 0.35$ & $5.47 \pm 0.39$ & $5.46 \pm 0.37$ \\
\hline Day 23 & $4.82 \pm 0.45$ & $5.07 \pm 0.50$ & $5.21 \pm 0.46$ & $6.15 \pm 0.57$ & $4.27 \pm 0.44$ & $5.15 \pm 0.53$ \\
\hline Week 14 & $4.15 \pm 0.35$ & $4.49 \pm 0.37$ & $4.28 \pm 0.45$ & $4.41 \pm 0.16$ & $3.60 \pm 0.25$ & $4.74 \pm 0.25$ \\
\hline \multicolumn{7}{|c|}{ Monocytes $\left(10^{3} / \mu \mathrm{L}\right)$} \\
\hline Day 4 & $0.20 \pm 0.02$ & $0.22 \pm 0.03$ & $0.23 \pm 0.02$ & $0.24 \pm 0.02$ & $0.21 \pm 0.02$ & $0.25 \pm 0.03$ \\
\hline Day 23 & $0.15 \pm 0.03$ & $0.18 \pm 0.03$ & $0.11 \pm 0.02$ & $0.15 \pm 0.03$ & $0.12 \pm 0.03$ & $0.18 \pm 0.02$ \\
\hline Week 14 & $0.18 \pm 0.03$ & $0.17 \pm 0.03$ & $0.14 \pm 0.02$ & $0.17 \pm 0.01$ & $0.15 \pm 0.02$ & $0.18 \pm 0.02$ \\
\hline \multicolumn{7}{|c|}{ Basophils $\left(10^{3} / \mu \mathrm{L}\right)$} \\
\hline Day 4 & $0.004 \pm 0.006$ & $0.052 \pm 0.012$ & $0.061 \pm 0.013$ & $0.055 \pm 0.010$ & $0.057 \pm 0.012$ & $0.058 \pm 0.007$ \\
\hline Day 23 & $0.028 \pm 0.006$ & $0.032 \pm 0.004$ & $0.021 \pm 0.007$ & $0.038 \pm 0.009$ & $0.024 \pm 0.005$ & $0.039 \pm 0.006$ \\
\hline Week 14 & $0.023 \pm 0.004$ & $0.028 \pm 0.006$ & $0.024 \pm 0.005$ & $0.029 \pm 0.003$ & $0.020 \pm 0.004$ & $0.035 \pm 0.005$ \\
\hline
\end{tabular}


5-Amino-o-cresol, NTP TOX 89

\begin{tabular}{|c|c|c|c|c|c|c|}
\hline & $\begin{array}{l}\text { Vehicle } \\
\text { Control }\end{array}$ & $2 \mathrm{mg} / \mathrm{kg}$ & $4 \mathrm{mg} / \mathrm{kg}$ & $8 \mathrm{mg} / \mathrm{kg}$ & $16 \mathrm{mg} / \mathrm{kg}$ & $32 \mathrm{mg} / \mathrm{kg}$ \\
\hline \multicolumn{7}{|c|}{ Eosinophils $\left(10^{3} / \mu \mathrm{L}\right)$} \\
\hline Day 4 & $0.09 \pm 0.01$ & $0.09 \pm 0.02$ & $0.09 \pm 0.01$ & $0.10 \pm 0.02$ & $0.10 \pm 0.02$ & $0.08 \pm 0.00$ \\
\hline Day 23 & $0.10 \pm 0.01$ & $0.10 \pm 0.01$ & $0.10 \pm 0.02$ & $0.11 \pm 0.01$ & $0.08 \pm 0.02$ & $0.09 \pm 0.01$ \\
\hline Week 14 & $0.07 \pm 0.01$ & $0.07 \pm 0.01$ & $0.07 \pm 0.01$ & $0.07 \pm 0.01$ & $0.08 \pm 0.02$ & $0.10 \pm 0.01$ \\
\hline \multicolumn{7}{|c|}{ Clinical Chemistry } \\
\hline $\mathbf{n}$ & 10 & 10 & 10 & 10 & 10 & 10 \\
\hline \multicolumn{7}{|c|}{ Urea nitrogen $(\mathrm{mg} / \mathrm{dL})$} \\
\hline Day 4 & $9.8 \pm 0.6$ & $9.7 \pm 0.3$ & $11.0 \pm 0.6$ & $10.4 \pm 0.4$ & $10.7 \pm 0.4$ & $9.8 \pm 0.4$ \\
\hline Day 23 & $12.0 \pm 0.4$ & $12.4 \pm 0.4$ & $11.4 \pm 0.3$ & $12.0 \pm 0.4$ & $12.0 \pm 0.4$ & $11.3 \pm 0.4$ \\
\hline Week 14 & $15.9 \pm 0.4$ & $15.1 \pm 0.4$ & $14.9 \pm 0.6$ & $14.5 \pm 0.5$ & $15.5 \pm 0.7$ & $14.7 \pm 0.4$ \\
\hline \multicolumn{7}{|c|}{ Creatinine (mg/dL) } \\
\hline Day 4 & $0.37 \pm 0.02$ & $0.40 \pm 0.00$ & $0.39 \pm 0.01$ & $0.38 \pm 0.01$ & $0.40 \pm 0.00$ & $0.39 \pm 0.01$ \\
\hline Day 23 & $0.49 \pm 0.01$ & $0.50 \pm 0.00$ & $0.50 \pm 0.01$ & $0.46 \pm 0.02$ & $0.48 \pm 0.01$ & $0.49 \pm 0.01$ \\
\hline Week 14 & $0.59 \pm 0.01$ & $0.60 \pm 0.00$ & $0.62 \pm 0.01$ & $0.59 \pm 0.01$ & $0.59 \pm 0.02$ & $0.59 \pm 0.01$ \\
\hline \multicolumn{7}{|c|}{ Glucose (mg/dL) } \\
\hline Day 4 & $140 \pm 4$ & $133 \pm 3$ & $137 \pm 4$ & $142 \pm 3$ & $141 \pm 2$ & $135 \pm 3$ \\
\hline Day 23 & $134 \pm 2$ & $132 \pm 2$ & $131 \pm 2$ & $133 \pm 3$ & $136 \pm 2$ & $135 \pm 2$ \\
\hline Week 14 & $126 \pm 3$ & $126 \pm 4$ & $129 \pm 4$ & $125 \pm 2$ & $133 \pm 4$ & $128 \pm 4$ \\
\hline \multicolumn{7}{|c|}{ Total protein $(\mathrm{g} / \mathrm{dL})$} \\
\hline Day 4 & $5.6 \pm 0.1$ & $5.6 \pm 0.0$ & $5.7 \pm 0.1$ & $5.6 \pm 0.1$ & $5.5 \pm 0.0$ & $5.6 \pm 0.1$ \\
\hline Day 23 & $5.9 \pm 0.1$ & $6.0 \pm 0.1$ & $6.0 \pm 0.1$ & $6.0 \pm 0.1$ & $5.8 \pm 0.1$ & $6.0 \pm 0.1$ \\
\hline Week 14 & $7.3 \pm 0.1$ & $7.4 \pm 0.1$ & $7.3 \pm 0.1$ & $7.4 \pm 0.1$ & $7.4 \pm 0.1$ & $7.2 \pm 0.1$ \\
\hline \multicolumn{7}{|c|}{ Albumin $(\mathrm{g} / \mathrm{dL})$} \\
\hline Day 4 & $4.1 \pm 0.1$ & $4.1 \pm 0.0$ & $4.2 \pm 0.1$ & $4.1 \pm 0.1$ & $4.1 \pm 0.0$ & $4.1 \pm 0.1$ \\
\hline Day 23 & $4.3 \pm 0.0$ & $4.4 \pm 0.1$ & $4.3 \pm 0.1$ & $4.4 \pm 0.0$ & $4.2 \pm 0.1$ & $4.3 \pm 0.1$ \\
\hline Week 14 & $5.0 \pm 0.1$ & $4.9 \pm 0.1$ & $4.9 \pm 0.1$ & $5.0 \pm 0.1$ & $5.0 \pm 0.1$ & $4.8 \pm 0.1$ \\
\hline \multicolumn{7}{|c|}{ Alanine aminotransferase (IU/L) } \\
\hline Day 4 & $56 \pm 1$ & $57 \pm 3$ & $54 \pm 2$ & $58 \pm 2$ & $54 \pm 2$ & $59 \pm 2$ \\
\hline Day 23 & $33 \pm 1$ & $35 \pm 1$ & $33 \pm 1$ & $33 \pm 1$ & $33 \pm 1$ & $35 \pm 1$ \\
\hline Week 14 & $60 \pm 4$ & $74 \pm 13$ & $62 \pm 5$ & $57 \pm 3$ & $57 \pm 3$ & $52 \pm 3$ \\
\hline \multicolumn{7}{|c|}{ Alkaline phosphatase (IU/L) } \\
\hline Day 4 & $587 \pm 12$ & $568 \pm 26$ & $577 \pm 8$ & $596 \pm 12$ & $562 \pm 18$ & $609 \pm 17$ \\
\hline Day 23 & $353 \pm 5$ & $349 \pm 8$ & $357 \pm 6$ & $366 \pm 6$ & $350 \pm 8$ & $350 \pm 9$ \\
\hline Week 14 & $226 \pm 5$ & $223 \pm 9$ & $225 \pm 9$ & $229 \pm 5$ & $221 \pm 5$ & $222 \pm 6$ \\
\hline
\end{tabular}


5-Amino-o-cresol, NTP TOX 89

\begin{tabular}{|c|c|c|c|c|c|c|}
\hline & $\begin{array}{l}\text { Vehicle } \\
\text { Control }\end{array}$ & $2 \mathrm{mg} / \mathrm{kg}$ & $4 \mathrm{mg} / \mathrm{kg}$ & $8 \mathrm{mg} / \mathrm{kg}$ & $16 \mathrm{mg} / \mathrm{kg}$ & $32 \mathrm{mg} / \mathrm{kg}$ \\
\hline \multicolumn{7}{|c|}{ Creatine kinase (IU/L) } \\
\hline Day 4 & $489 \pm 79$ & $607 \pm 116$ & $553 \pm 64$ & $488 \pm 53$ & $579 \pm 128$ & $441 \pm 72$ \\
\hline Day 23 & $355 \pm 48$ & $286 \pm 25$ & $337 \pm 28$ & $332 \pm 41$ & $355 \pm 42$ & $362 \pm 37$ \\
\hline Week 14 & $247 \pm 36$ & $287 \pm 57$ & $311 \pm 57$ & $293 \pm 46^{\mathrm{b}}$ & $315 \pm 63$ & $254 \pm 35$ \\
\hline \multicolumn{7}{|c|}{ Sorbitol dehydrogenase (IU/L) } \\
\hline Day 4 & $13 \pm 0$ & $12 \pm 1$ & $13 \pm 1$ & $13 \pm 1$ & $12 \pm 1$ & $13 \pm 0$ \\
\hline Day 23 & $14 \pm 1$ & $15 \pm 1$ & $15 \pm 1$ & $15 \pm 0$ & $14 \pm 1$ & $15 \pm 1$ \\
\hline Week 14 & $16 \pm 1$ & $19 \pm 3$ & $18 \pm 1$ & $16 \pm 1$ & $16 \pm 1$ & $15 \pm 1$ \\
\hline \multicolumn{7}{|c|}{ Bile acids $(\mu \mathrm{mol} / \mathrm{L})$} \\
\hline Day 4 & $25.0 \pm 3.4$ & $18.6 \pm 2.3$ & $19.6 \pm 3.3$ & $22.9 \pm 3.7$ & $24.4 \pm 3.6$ & $23.4 \pm 2.2$ \\
\hline Day 23 & $17.4 \pm 2.8$ & $11.7 \pm 2.2$ & $11.6 \pm 1.7$ & $11.2 \pm 2.1$ & $12.4 \pm 2.0$ & $11.4 \pm 1.5$ \\
\hline Week 14 & $12.8 \pm 1.9$ & $15.2 \pm 2.4$ & $14.4 \pm 2.4$ & $9.9 \pm 1.6$ & $13.3 \pm 2.3$ & $14.7 \pm 2.3$ \\
\hline \multicolumn{7}{|c|}{ Total thyroxine $(\mathrm{mmol} / \mathrm{L})$} \\
\hline Week 14 & $3.01 \pm 0.26$ & $3.17 \pm 0.20$ & $3.79 \pm 0.29$ & $3.53 \pm 0.34$ & $3.18 \pm 0.38$ & $3.59 \pm 0.33$ \\
\hline
\end{tabular}

*Significantly different $(\mathrm{P} \leq 0.05)$ from the vehicle control group by Dunn's test.

$* * \mathrm{P} \leq 0.01$.

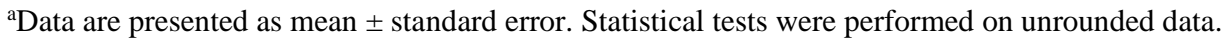
${ }^{b} \mathrm{n}=9$. 
Table B-2. Hematology Data for Mice in the Three-month Dermal Study of 5-Amino-o-cresol ${ }^{\mathrm{a}}$

\begin{tabular}{|c|c|c|c|c|c|c|}
\hline & $\begin{array}{l}\text { Vehicle } \\
\text { Control }\end{array}$ & $8 \mathrm{mg} / \mathrm{kg}$ & $16 \mathrm{mg} / \mathrm{kg}$ & $32 \mathrm{mg} / \mathrm{kg}$ & $64 \mathrm{mg} / \mathrm{kg}$ & $128 \mathrm{mg} / \mathrm{kg}$ \\
\hline \multicolumn{7}{|l|}{ Male } \\
\hline n & 10 & 10 & 10 & 9 & 10 & 9 \\
\hline Hematocrit (\%) & $51.3 \pm 0.8$ & $50.9 \pm 0.3$ & $50.7 \pm 0.7$ & $50.8 \pm 0.7$ & $50.6 \pm 0.4$ & $50.5 \pm 0.4$ \\
\hline Hemoglobin (g/dL) & $15.9 \pm 0.3$ & $15.7 \pm 0.1$ & $15.7 \pm 0.2$ & $15.7 \pm 0.2$ & $15.7 \pm 0.2$ & $15.6 \pm 0.1$ \\
\hline Erythrocytes $\left(10^{6} / \mu \mathrm{L}\right)$ & $10.36 \pm 0.15$ & $10.35 \pm 0.06$ & $10.37 \pm 0.14$ & $10.25 \pm 0.11$ & $10.30 \pm 0.07$ & $10.28 \pm 0.08$ \\
\hline Reticulocytes $\left(10^{3} / \mu \mathrm{L}\right)$ & $274 \pm 9$ & $287 \pm 8$ & $283 \pm 6$ & $280 \pm 8$ & $268 \pm 7$ & $277 \pm 13$ \\
\hline Mean cell volume (fL) & $49.5 \pm 0.1$ & $49.2 \pm 0.2$ & $48.9 \pm 0.1$ & $49.5 \pm 0.3$ & $49.2 \pm 0.2$ & $49.2 \pm 0.2$ \\
\hline $\begin{array}{l}\text { Mean cell hemoglobin } \\
\text { (pg) }\end{array}$ & $15.4 \pm 0.1$ & $15.2 \pm 0.1$ & $15.1 \pm 0.1$ & $15.3 \pm 0.1$ & $15.2 \pm 0.1$ & $15.2 \pm 0.1$ \\
\hline $\begin{array}{l}\text { Mean cell hemoglobin } \\
\text { concentration }(\mathrm{g} / \mathrm{dL})\end{array}$ & $31.1 \pm 0.1$ & $30.9 \pm 0.1$ & $31.0 \pm 0.1$ & $30.9 \pm 0.1$ & $30.9 \pm 0.1$ & $30.9 \pm 0.2$ \\
\hline Platelets $\left(10^{3} / \mu \mathrm{L}\right)$ & $999 \pm 34$ & $1,027 \pm 29$ & $966 \pm 42$ & $1,003 \pm 17$ & $995 \pm 33$ & $1,071 \pm 30$ \\
\hline Leukocytes $\left(10^{3} / \mu \mathrm{L}\right)$ & $4.81 \pm 0.52$ & $5.09 \pm 0.43$ & $4.70 \pm 0.35$ & $4.61 \pm 0.21$ & $4.70 \pm 0.31$ & $4.90 \pm 0.37$ \\
\hline $\begin{array}{l}\text { Segmented neutrophils } \\
\left(10^{3} / \mu \mathrm{L}\right)\end{array}$ & $0.64 \pm 0.05$ & $0.69 \pm 0.06$ & $0.65 \pm 0.05$ & $0.64 \pm 0.05$ & $0.69 \pm 0.07$ & $0.72 \pm 0.07$ \\
\hline Lymphocytes $\left(10^{3} / \mu \mathrm{L}\right)$ & $3.89 \pm 0.44$ & $4.13 \pm 0.38$ & $3.76 \pm 0.28$ & $3.69 \pm 0.20$ & $3.76 \pm 0.25$ & $3.89 \pm 0.31$ \\
\hline Monocytes $\left(10^{3} / \mu \mathrm{L}\right)$ & $0.19 \pm 0.03$ & $0.19 \pm 0.02$ & $0.21 \pm 0.03$ & $0.20 \pm 0.02$ & $0.17 \pm 0.03$ & $0.21 \pm 0.02$ \\
\hline Basophils $\left(10^{3} / \mu \mathrm{L}\right)$ & $0.009 \pm 0.002$ & $0.010 \pm 0.002$ & $0.009 \pm 0.001$ & $0.006 \pm 0.002$ & $0.005 \pm 0.002$ & $0.011 \pm 0.001$ \\
\hline Eosinophils $\left(10^{3} / \mu \mathrm{L}\right)$ & $0.08 \pm 0.02$ & $0.08 \pm 0.01$ & $0.08 \pm 0.01$ & $0.06 \pm 0.01$ & $0.07 \pm 0.02$ & $0.07 \pm 0.01$ \\
\hline
\end{tabular}

\section{Female}

\begin{tabular}{lcccccc}
$\mathbf{n}$ & 10 & 10 & 10 & 7 & 10 & 10 \\
\hline Hematocrit $(\%)$ & $51.2 \pm 0.7$ & $51.7 \pm 0.4$ & $52.7 \pm 0.9$ & $50.7 \pm 0.4$ & $51.3 \pm 0.6$ & $51.2 \pm 0.4$ \\
Hemoglobin $(\mathrm{g} / \mathrm{dL})$ & $16.2 \pm 0.3$ & $16.3 \pm 0.2$ & $16.6 \pm 0.3$ & $16.0 \pm 0.1$ & $16.2 \pm 0.2$ & $16.1 \pm 0.2$ \\
Erythrocytes $\left(10^{6} / \mu \mathrm{L}\right)$ & $10.33 \pm 0.15$ & $10.39 \pm 0.10$ & $10.54 \pm 0.17$ & $10.14 \pm 0.09$ & $10.31 \pm 0.11$ & $10.31 \pm 0.09$ \\
Reticulocytes $\left(10^{3} / \mu \mathrm{L}\right)$ & $273 \pm 14$ & $283 \pm 20$ & $293 \pm 12$ & $254 \pm 9$ & $279 \pm 15$ & $274 \pm 10$ \\
Mean cell volume (fL) & $49.6 \pm 0.1$ & $49.7 \pm 0.2$ & $50.0 \pm 0.2$ & $50.0 \pm 0.1$ & $49.7 \pm 0.1$ & $49.7 \pm 0.2$ \\
Mean cell hemoglobin & $15.7 \pm 0.1$ & $15.7 \pm 0.1$ & $15.8 \pm 0.1$ & $15.8 \pm 0.1$ & $15.7 \pm 0.1$ & $15.6 \pm 0.1$ \\
$\quad(\mathrm{pg})$ & & & & & & \\
Mean cell hemoglobin & $31.6 \pm 0.1$ & $31.5 \pm 0.2$ & $31.5 \pm 0.1$ & $31.6 \pm 0.1$ & $31.5 \pm 0.2$ & $31.4 \pm 0.1$ \\
$\quad$ concentration $(\mathrm{g} / \mathrm{dL})$ & & & & & & \\
Platelets $\left(10^{3} / \mu \mathrm{L}\right)$ & $907 \pm 37$ & $911 \pm 39$ & $859 \pm 30$ & $949 \pm 33$ & $905 \pm 67$ & $848 \pm 48$ \\
Leukocytes $\left(10^{3} / \mu \mathrm{L}\right)$ & $5.02 \pm 0.27$ & $5.43 \pm 0.41$ & $4.76 \pm 0.32$ & $4.97 \pm 0.35$ & $4.91 \pm 0.39$ & $5.04 \pm 0.33$ \\
Segmented neutrophils & $0.77 \pm 0.05$ & $0.70 \pm 0.06$ & $0.79 \pm 0.10$ & $0.65 \pm 0.09$ & $0.72 \pm 0.10$ & $0.77 \pm 0.08$ \\
$\quad\left(10^{3} / \mu \mathrm{L}\right)$ & & & & & & \\
Lymphocytes $\left(10^{3} / \mu \mathrm{L}\right)$ & $4.01 \pm 0.27$ & $4.50 \pm 0.34$ & $3.77 \pm 0.23$ & $4.07 \pm 0.26$ & $3.93 \pm 0.28$ & $4.07 \pm 0.30$ \\
Monocytes $\left(10^{3} / \mu \mathrm{L}\right)$ & $0.12 \pm 0.01$ & $0.14 \pm 0.02$ & $0.13 \pm 0.02$ & $0.15 \pm 0.04$ & $0.14 \pm 0.02$ & $0.11 \pm 0.02$ \\
Basophils $\left(10^{3} / \mu \mathrm{L}\right)$ & $0.015 \pm 0.002$ & $0.015 \pm 0.003$ & $0.010 \pm 0.002$ & $0.011 \pm 0.003$ & $0.011 \pm 0.003$ & $0.011 \pm 0.003$ \\
Eosinophils $\left(10^{3} / \mu \mathrm{L}\right)$ & $0.10 \pm 0.01$ & $0.08 \pm 0.01$ & $0.06 \pm 0.01$ & $0.09 \pm 0.02$ & $0.11 \pm 0.02$ & $0.08 \pm 0.01$ \\
\hline
\end{tabular}

a Data are presented as mean \pm standard error. Statistical tests were performed on unrounded data. 


\section{Appendix C. Organ Weights and Organ-Weight-to-Body- Weight Ratios}

\section{Tables}

Table C-1. Organ Weights and Organ-Weight-to-Body-Weight Ratios for Rats in the Three-month Dermal Study of 5-Amino-o-cresol.

Table C-2. Organ Weights and Organ-Weight-to-Body-Weight Ratios for Mice in the Three-month Dermal Study of 5-Amino-o-cresol. C-3 
Table C-1. Organ Weights and Organ-Weight-to-Body-Weight Ratios for Rats in the Three-month Dermal Study of 5-Amino-o-cresol ${ }^{\mathrm{a}}$

\begin{tabular}{|c|c|c|c|c|c|c|}
\hline & $\begin{array}{l}\text { Vehicle } \\
\text { Control }\end{array}$ & $2 \mathrm{mg} / \mathrm{kg}$ & $4 \mathrm{mg} / \mathrm{kg}$ & $8 \mathrm{mg} / \mathrm{kg}$ & $16 \mathrm{mg} / \mathrm{kg}$ & $32 \mathrm{mg} / \mathrm{kg}$ \\
\hline $\mathbf{n}$ & 10 & 10 & 10 & 10 & 10 & 10 \\
\hline \multicolumn{7}{|l|}{ Male } \\
\hline Necropsy body wt & $324 \pm 6$ & $324 \pm 5$ & $329 \pm 7$ & $339 \pm 5$ & $333 \pm 7$ & $333 \pm 4$ \\
\hline \multicolumn{7}{|l|}{ Heart } \\
\hline Absolute & $0.95 \pm 0.02$ & $0.95 \pm 0.02$ & $0.98 \pm 0.02$ & $1.02 \pm 0.03^{*}$ & $0.99 \pm 0.02$ & $0.98 \pm 0.01$ \\
\hline Relative & $2.93 \pm 0.05$ & $2.94 \pm 0.04$ & $2.98 \pm 0.04$ & $3.02 \pm 0.08$ & $2.98 \pm 0.04$ & $2.94 \pm 0.04$ \\
\hline \multicolumn{7}{|l|}{ R. Kidney } \\
\hline Absolute & $1.07 \pm 0.03$ & $1.05 \pm 0.01$ & $1.10 \pm 0.04$ & $1.13 \pm 0.02$ & $1.09 \pm 0.02$ & $1.12 \pm 0.02$ \\
\hline Relative & $3.30 \pm 0.06$ & $3.23 \pm 0.05$ & $3.35 \pm 0.05$ & $3.34 \pm 0.05$ & $3.27 \pm 0.04$ & $3.37 \pm 0.03$ \\
\hline \multicolumn{7}{|l|}{ Liver } \\
\hline Absolute & $12.46 \pm 0.36$ & $12.69 \pm 0.33$ & $12.99 \pm 0.35$ & $13.90 \pm 0.29 * *$ & $13.12 \pm 0.24$ & $13.34 \pm 0.25$ \\
\hline Relative & $38.39 \pm 0.53$ & $39.12 \pm 0.84$ & $39.52 \pm 0.49$ & $41.02 \pm 0.62 *$ & $39.44 \pm 0.44$ & $40.04 \pm 0.69$ \\
\hline \multicolumn{7}{|l|}{ Lung } \\
\hline Absolute & $1.87 \pm 0.09$ & $2.00 \pm 0.08$ & $2.04 \pm 0.10$ & $2.01 \pm 0.06$ & $2.08 \pm 0.11$ & $2.00 \pm 0.07$ \\
\hline Relative & $5.76 \pm 0.25$ & $6.16 \pm 0.20$ & $6.22 \pm 0.28$ & $5.95 \pm 0.18$ & $6.25 \pm 0.29$ & $6.00 \pm 0.22$ \\
\hline \multicolumn{7}{|l|}{ R. Testis } \\
\hline Absolute & $1.385 \pm 0.025$ & $1.375 \pm 0.020$ & $1.397 \pm 0.015$ & $1.375 \pm 0.020$ & $1.393 \pm 0.019$ & $0.410 \pm 0.018$ \\
\hline Relative & $4.279 \pm 0.079$ & $4.250 \pm 0.104$ & $4.264 \pm 0.067$ & $4.061 \pm 0.055$ & $4.197 \pm 0.092$ & $4.233 \pm 0.051$ \\
\hline \multicolumn{7}{|l|}{ Thymus } \\
\hline Absolute & $0.346 \pm 0.012$ & $0.325 \pm 0.006$ & $0.357 \pm 0.014$ & $0.368 \pm 0.017$ & $0.339 \pm 0.016$ & $0.334 \pm 0.010$ \\
\hline Relative & $1.070 \pm 0.041$ & $1.001 \pm 0.016$ & $1.085 \pm 0.034$ & $1.089 \pm 0.052$ & $1.013 \pm 0.031$ & $1.001 \pm 0.026$ \\
\hline \multicolumn{7}{|l|}{ Female } \\
\hline Necropsy body wt & $186 \pm 3$ & $188 \pm 4$ & $192 \pm 3$ & $185 \pm 3$ & $187 \pm 4$ & $184 \pm 3$ \\
\hline \multicolumn{7}{|l|}{ Heart } \\
\hline Absolute & $0.67 \pm 0.01$ & $0.67 \pm 0.02$ & $0.71 \pm 0.02$ & $0.66 \pm 0.01$ & $0.67 \pm 0.02$ & $0.66 \pm 0.01$ \\
\hline Relative & $3.62 \pm 0.06$ & $3.56 \pm 0.06$ & $3.68 \pm 0.11$ & $3.57 \pm 0.07$ & $3.60 \pm 0.05$ & $3.60 \pm 0.10$ \\
\hline \multicolumn{7}{|l|}{ R. Kidney } \\
\hline Absolute & $0.68 \pm 0.01$ & $0.69 \pm 0.02$ & $0.67 \pm 0.01$ & $0.67 \pm 0.01$ & $0.68 \pm 0.02$ & $0.66 \pm 0.01$ \\
\hline Relative & $3.68 \pm 0.04$ & $3.66 \pm 0.06$ & $3.50 \pm 0.04$ & $3.64 \pm 0.05$ & $3.64 \pm 0.06$ & $3.61 \pm 0.06$ \\
\hline \multicolumn{7}{|l|}{ Liver } \\
\hline Absolute & $7.04 \pm 0.12$ & $7.10 \pm 0.22$ & $7.19 \pm 0.20$ & $6.96 \pm 0.13$ & $6.99 \pm 0.23$ & $6.81 \pm 0.18$ \\
\hline Relative & $37.90 \pm 0.37$ & $37.82 \pm 0.77$ & $37.45 \pm 0.79$ & $37.62 \pm 0.42$ & $37.39 \pm 0.67$ & $37.11 \pm 0.92$ \\
\hline
\end{tabular}




\begin{tabular}{|c|c|c|c|c|c|c|}
\hline & $\begin{array}{l}\text { Vehicle } \\
\text { Control }\end{array}$ & $2 \mathrm{mg} / \mathrm{kg}$ & $4 \mathrm{mg} / \mathrm{kg}$ & $8 \mathrm{mg} / \mathrm{kg}$ & $16 \mathrm{mg} / \mathrm{kg}$ & $32 \mathrm{mg} / \mathrm{kg}$ \\
\hline \multicolumn{7}{|l|}{ Lung } \\
\hline Absolute & $1.46 \pm 0.06$ & $1.37 \pm 0.06$ & $1.53 \pm 0.07$ & $1.40 \pm 0.04$ & $1.37 \pm 0.04$ & $1.40 \pm 0.10$ \\
\hline Relative & $7.83 \pm 0.28$ & $7.29 \pm 0.24$ & $8.00 \pm 0.41$ & $7.59 \pm 0.21$ & $7.36 \pm 0.26$ & $7.64 \pm 0.56$ \\
\hline \multicolumn{7}{|l|}{ Thymus } \\
\hline Absolute & $0.257 \pm 0.007$ & $0.270 \pm 0.013$ & $0.282 \pm 0.012$ & $0.258 \pm 0.010$ & $0.271 \pm 0.008$ & $0.261 \pm 0.009$ \\
\hline Relative & $1.387 \pm 0.044$ & $1.436 \pm 0.058$ & $1.471 \pm 0.058$ & $1.392 \pm 0.040$ & $1.456 \pm 0.044$ & $1.417 \pm 0.038$ \\
\hline \multirow{2}{*}{\multicolumn{7}{|c|}{$\begin{array}{l}\text { *Significantly different }(\mathrm{P} \leq 0.05) \text { from the vehicle control group by Dunnett's test. } \\
\text { **P } \leq 0.01 \text {. } \\
\text { aOrgan weights (absolute weights) and body weights are given in grams; organ-weight-to-body-weight ratios (relative weights) } \\
\text { are given as mg organ weight/g body weight (mean } \pm \text { standard error). } \\
\text { Table C-2. Organ Weights and Organ-Weight-to-Body-Weight Ratios for Mice in the Three-month } \\
\text { Dermal Study of 5-Amino-o-cresol }\end{array}$}} \\
\hline & & & & & & \\
\hline & $\begin{array}{l}\text { Vehicle } \\
\text { Control }\end{array}$ & $8 \mathrm{mg} / \mathrm{kg}$ & $16 \mathrm{mg} / \mathrm{kg}$ & $32 \mathrm{mg} / \mathrm{kg}$ & $64 \mathrm{mg} / \mathrm{kg}$ & $128 \mathrm{mg} / \mathrm{kg}$ \\
\hline \multicolumn{7}{|l|}{ Male } \\
\hline $\mathbf{n}$ & 10 & 10 & 10 & 10 & 10 & 10 \\
\hline Necropsy body wt & $41.8 \pm 0.8$ & $41.1 \pm 0.9$ & $42.3 \pm 0.7$ & $42.7 \pm 1.1$ & $42.1 \pm 1.0$ & $42.5 \pm 1.1$ \\
\hline \multicolumn{7}{|l|}{ Heart } \\
\hline Absolute & $0.19 \pm 0.01$ & $0.20 \pm 0.01$ & $0.21 \pm 0.01$ & $0.21 \pm 0.01$ & $0.19 \pm 0.01$ & $0.19 \pm 0.01$ \\
\hline Relative & $4.62 \pm 0.17$ & $4.96 \pm 0.09$ & $4.85 \pm 0.18$ & $4.78 \pm 0.24$ & $4.54 \pm 0.14$ & $4.46 \pm 0.21$ \\
\hline \multicolumn{7}{|l|}{ R. Kidney } \\
\hline Absolute & $0.31 \pm 0.01$ & $0.30 \pm 0.01$ & $0.31 \pm 0.00$ & $0.31 \pm 0.01$ & $0.32 \pm 0.01$ & $0.30 \pm 0.01$ \\
\hline Relative & $7.34 \pm 0.21$ & $7.37 \pm 0.14$ & $7.23 \pm 0.09$ & $7.26 \pm 0.11$ & $7.53 \pm 0.11$ & $7.04 \pm 0.19$ \\
\hline \multicolumn{7}{|l|}{ Liver } \\
\hline Absolute & $1.92 \pm 0.06$ & $1.85 \pm 0.08$ & $1.92 \pm 0.05$ & $2.03 \pm 0.08$ & $2.03 \pm 0.09$ & $2.00 \pm 0.09$ \\
\hline Relative & $45.84 \pm 0.84$ & $44.68 \pm 1.07$ & $45.26 \pm 0.79$ & $47.39 \pm 0.79$ & $48.17 \pm 1.09$ & $47.04 \pm 1.06$ \\
\hline \multicolumn{7}{|l|}{ Lung } \\
\hline Absolute & $0.28 \pm 0.02$ & $0.26 \pm 0.01$ & $0.26 \pm 0.02$ & $0.28 \pm 0.02$ & $0.25 \pm 0.01$ & $0.25 \pm 0.01$ \\
\hline Relative & $6.69 \pm 0.55$ & $6.24 \pm 0.37$ & $6.22 \pm 0.33$ & $6.57 \pm 0.31$ & $6.04 \pm 0.36$ & $5.85 \pm 0.25$ \\
\hline \multicolumn{7}{|l|}{ R. Testis } \\
\hline Absolute & $0.119 \pm 0.002$ & $0.123 \pm 0.002$ & $0.120 \pm 0.003$ & $0.123 \pm 0.003$ & $0.118 \pm 0.005$ & $0.118 \pm 0.002$ \\
\hline Relative & $2.850 \pm 0.064$ & $3.006 \pm 0.058$ & $2.839 \pm 0.081$ & $2.884 \pm 0.070$ & $2.799 \pm 0.087$ & $2.796 \pm 0.075$ \\
\hline \multicolumn{7}{|l|}{ Thymus } \\
\hline Absolute & $0.071 \pm 0.007$ & $0.065 \pm 0.004$ & $0.065 \pm 0.005$ & $0.074 \pm 0.003$ & $0.066 \pm 0.004$ & $0.067 \pm 0.005$ \\
\hline Relative & $1.686 \pm 0.158$ & $1.585 \pm 0.111$ & $1.520 \pm 0.107$ & $1.726 \pm 0.078$ & $1.581 \pm 0.097$ & $1.571 \pm 0.098$ \\
\hline
\end{tabular}


5-Amino-o-cresol, NTP TOX 89

\begin{tabular}{|c|c|c|c|c|c|c|}
\hline & $\begin{array}{l}\text { Vehicle } \\
\text { Control }\end{array}$ & $8 \mathrm{mg} / \mathrm{kg}$ & $16 \mathrm{mg} / \mathrm{kg}$ & $32 \mathrm{mg} / \mathrm{kg}$ & $64 \mathrm{mg} / \mathrm{kg}$ & $128 \mathrm{mg} / \mathrm{kg}$ \\
\hline \multicolumn{7}{|l|}{ Female } \\
\hline $\mathbf{n}$ & 10 & 10 & 9 & 10 & 10 & 10 \\
\hline Necropsy body wt & $37.6 \pm 1.0$ & $37.7 \pm 1.6$ & $38.8 \pm 1.1$ & $39.0 \pm 1.5$ & $36.4 \pm 1.7$ & $36.3 \pm 1.1$ \\
\hline \multicolumn{7}{|l|}{ Heart } \\
\hline Absolute & $0.18 \pm 0.01$ & $0.18 \pm 0.01$ & $0.20 \pm 0.01$ & $0.18 \pm 0.00$ & $0.18 \pm 0.01$ & $0.17 \pm 0.01$ \\
\hline Relative & $4.75 \pm 0.26$ & $4.69 \pm 0.19$ & $5.13 \pm 0.23$ & $4.61 \pm 0.18$ & $5.12 \pm 0.34$ & $4.58 \pm 0.25$ \\
\hline \multicolumn{7}{|l|}{ R. Kidney } \\
\hline Absolute & $0.20 \pm 0.00$ & $0.20 \pm 0.01$ & $0.20 \pm 0.00$ & $0.20 \pm 0.00$ & $0.19 \pm 0.01$ & $0.19 \pm 0.00$ \\
\hline Relative & $5.39 \pm 0.17$ & $5.32 \pm 0.19$ & $5.25 \pm 0.12$ & $5.16 \pm 0.19$ & $5.08 \pm 0.39$ & $5.34 \pm 0.15$ \\
\hline \multicolumn{7}{|l|}{ Liver } \\
\hline Absolute & $1.62 \pm 0.02$ & $1.60 \pm 0.05$ & $1.64 \pm 0.04$ & $1.64 \pm 0.05$ & $1.61 \pm 0.04$ & $1.57 \pm 0.03$ \\
\hline Relative & $43.25 \pm 0.72$ & $42.67 \pm 0.98$ & $42.27 \pm 0.69$ & $42.22 \pm 0.80$ & $44.63 \pm 1.26$ & $43.28 \pm 0.86$ \\
\hline \multicolumn{7}{|l|}{ Lung } \\
\hline Absolute & $0.27 \pm 0.02$ & $0.29 \pm 0.02$ & $0.29 \pm 0.02$ & $0.28 \pm 0.01$ & $0.27 \pm 0.01$ & $0.27 \pm 0.01$ \\
\hline Relative & $7.19 \pm 0.54$ & $7.59 \pm 0.45$ & $7.63 \pm 0.45$ & $7.36 \pm 0.28$ & $7.60 \pm 0.58$ & $7.43 \pm 0.41$ \\
\hline \multicolumn{7}{|l|}{ Thymus } \\
\hline Absolute & $0.075 \pm 0.005$ & $0.068 \pm 0.004$ & $0.070 \pm 0.005$ & $0.067 \pm 0.004$ & $0.065 \pm 0.003$ & $0.068 \pm 0.005$ \\
\hline Relative & $1.984 \pm 0.100$ & $1.807 \pm 0.108$ & $1.801 \pm 0.098$ & $1.730 \pm 0.081$ & $1.786 \pm 0.067$ & $1.852 \pm 0.106$ \\
\hline
\end{tabular}

argan weights (absolute weights) and body weights are given in grams; organ-weight-to-body-weight ratios (relative weights) are given as $\mathrm{mg}$ organ weight/g body weight (mean \pm standard error). Differences from the vehicle control group were not significant by Dunnett's test. 


\section{Appendix D. Reproductive Tissue Evaluations and Estrous Cycle Characterization}

\section{Tables}

Table D-1. Summary of Reproductive Tissue Evaluations for Male Rats in the Threemonth Dermal Study of 5-Amino-o-cresol

Table D-2. Estrous Cycle Characterization for Female Rats in the Three-month Dermal Study of 5-Amino- $\mathrm{O}$-cresol......................................................................... D-2

Table D-3. Summary of Reproductive Tissue Evaluations for Male Mice in the Threemonth Dermal Study of 5-Amino-o-cresol

Table D-4. Estrous Cycle Characterization for Female Mice in the Three-month Dermal

Study of 5-Amino-o-cresol D-3 
Table D-1. Summary of Reproductive Tissue Evaluations for Male Rats in the Three-month Dermal Study of 5-Amino-o-cresol ${ }^{\mathrm{a}}$

\begin{tabular}{|c|c|c|c|c|}
\hline & $\begin{array}{l}\text { Vehicle } \\
\text { Control }\end{array}$ & $8 \mathrm{mg} / \mathrm{kg}$ & $16 \mathrm{mg} / \mathrm{kg}$ & $32 \mathrm{mg} / \mathrm{kg}$ \\
\hline $\mathbf{n}$ & 10 & 10 & 10 & 10 \\
\hline \multicolumn{5}{|l|}{ Weights (g) } \\
\hline Necropsy body wt & $324 \pm 6$ & $339 \pm 5$ & $333 \pm 7$ & $333 \pm 4$ \\
\hline L. Cauda epididymis & $0.1387 \pm 0.0045$ & $0.1358 \pm 0.0023$ & $0.1387 \pm 0.0039$ & $0.1426 \pm 0.0046$ \\
\hline L. Epididymis & $0.4109 \pm 0.0080$ & $0.4094 \pm 0.0054$ & $0.4121 \pm 0.0048$ & $0.4135 \pm 0.0055$ \\
\hline L. Testis & $1.4154 \pm 0.0148$ & $1.4127 \pm 0.0137$ & $1.4519 \pm 0.0156$ & $1.4611 \pm 0.0165$ \\
\hline \multicolumn{5}{|l|}{ Spermatid measurements } \\
\hline Spermatid heads ( $10^{6} / \mathrm{g}$ testis) & $157.0 \pm 4.6$ & $157.0 \pm 5.4$ & $160.0 \pm 5.1$ & $153.1 \pm 5.3$ \\
\hline Spermatid heads ( $10^{6} /$ testis $)$ & $187.4 \pm 6.1$ & $185.9 \pm 5.2$ & $196.1 \pm 6.5$ & $183.8 \pm 4.3$ \\
\hline \multicolumn{5}{|l|}{ Epididymal spermatozoal measurements } \\
\hline Sperm motility (\%) & $84 \pm 0$ & $84 \pm 0$ & $85 \pm 1$ & $85 \pm 0$ \\
\hline Sperm ( $10^{6} / g$ cauda epididymis $)$ & $789.1 \pm 48.3$ & $744.2 \pm 84.7$ & $811.9 \pm 36.9$ & $787.7 \pm 30.2$ \\
\hline Sperm (10\%/cauda epididymis) & $109.3 \pm 7.1$ & $100.8 \pm 11.1$ & $112.1 \pm 4.8$ & $113.0 \pm 6.9$ \\
\hline \multirow{2}{*}{\multicolumn{5}{|c|}{$\begin{array}{l}\text { 'Data are presented as mean } \pm \text { standard error. Differences from the vehicle control group are not significant by Dunnett's test } \\
\text { (body and tissue weights) or Dunn's test (spermatid and epididymal spermatozoal measurements). } \\
\text { Table D-2. Estrous Cycle Characterization for Female Rats in the Three-month Dermal Study of } \\
\text { 5-Amino-o-cresol }{ }^{\text {a }}\end{array}$}} \\
\hline & & & & \\
\hline & Vehicle Control & $8 \mathrm{mg} / \mathrm{kg}$ & $16 \mathrm{mg} / \mathrm{kg}$ & $32 \mathrm{mg} / \mathrm{kg}$ \\
\hline Number weighed at necropsy & 10 & 10 & 10 & 10 \\
\hline Necropsy body wt (g) & $186 \pm 3$ & $185 \pm 3$ & $187 \pm 4$ & $184 \pm 3$ \\
\hline Proportion of regular cycling females ${ }^{b}$ & $10 / 10$ & $9 / 10$ & $10 / 10$ & $10 / 10$ \\
\hline Estrous cycle length (days) & $5.0 \pm 0.00$ & $5.0 \pm 0.05$ & $5.0 \pm 0.00$ & $5.0 \pm 0.00$ \\
\hline \multicolumn{5}{|l|}{ Estrous stages ( $\%$ of cycle) } \\
\hline Diestrus & 58.8 & 62.5 & 60.0 & 60.0 \\
\hline Proestrus & 13.8 & 15.0 & 17.5 & 18.8 \\
\hline Estrus & 26.9 & 21.9 & 21.3 & 20.6 \\
\hline Metestrus & 0.6 & 0.6 & 1.3 & 0.6 \\
\hline
\end{tabular}

${ }^{a}$ Necropsy body weights and estrous cycle length data are presented as mean \pm standard error. Differences from the vehicle control group are not significant by Dunnett's test (body weights) or Dunn's test (estrous cycle length). By multivariate analysis of variance, dosed females do not differ significantly from the vehicle control females in the relative length of time spent in the estrous stages. Tests for equality of transition probability matrices among all groups and between the vehicle control group and each dosed group indicated no significant differences in the probability of an altered cycle for any treated group compared to the vehicle controls.

${ }^{\mathrm{b}}$ Number of females with a regular cycle/number of females cycling. 
Table D-3. Summary of Reproductive Tissue Evaluations for Male Mice in the Three-month Dermal Study of 5-Amino-o-cresol ${ }^{\mathrm{a}}$

\begin{tabular}{lcccc}
\hline & Vehicle Control & $\mathbf{3 2} \mathbf{~ m g / k g}$ & $\mathbf{6 4} \mathbf{~ m g} / \mathbf{k g}$ & $\mathbf{1 2 8} \mathbf{~ m g} / \mathbf{k g}$ \\
\hline $\mathbf{n}$ & 10 & 10 & 10 & 10 \\
\hline Weights (g) & & & & \\
$\quad$ Necropsy body wt & $41.8 \pm 0.8$ & $42.7 \pm 1.1$ & $42.1 \pm 1.0$ & $42.5 \pm 1.1$ \\
L. Cauda epididymis & $0.0145 \pm 0.0004$ & $0.0137 \pm 0.0004$ & $0.0144 \pm 0.0006$ & $0.0144 \pm 0.0006$ \\
L. Epididymis & $0.0422 \pm 0.0006$ & $0.0417 \pm 0.0008$ & $0.0419 \pm 0.0011$ & $0.0418 \pm 0.0007$ \\
L. Testis & $0.1147 \pm 0.0018$ & $0.1150 \pm 0.0021$ & $0.1120 \pm 0.0029$ & $0.1112 \pm 0.0027$ \\
Spermatid measurements & & & & \\
$\quad$ Spermatid heads (10\%/g testis) & $233.4 \pm 7.8$ & $225.6 \pm 8.0$ & $220.1 \pm 8.4$ & $228.2 \pm 7.3$ \\
Spermatid heads (10\%/testis) & $23.2 \pm 0.8$ & $22.0 \pm 1.1$ & $21.1 \pm 1.2$ & $20.7 \pm 0.9$ \\
Epididymal spermatozoal measurements & & & & \\
$\quad$ Sperm motility (\%) & $87 \pm 1$ & $88 \pm 0$ & $88 \pm 0$ & $88 \pm 1$ \\
Sperm (10\%/g cauda epididymis) & $1,440.3 \pm 82.6$ & $1,451.0 \pm 140.5$ & $1,192.7 \pm 98.4$ & $1,383.7 \pm 147.1$ \\
$\quad$ Sperm (10\%/cauda epididymis) & $20.8 \pm 1.2$ & $19.7 \pm 1.7$ & $17.0 \pm 1.3$ & $19.6 \pm 1.9$ \\
\hline
\end{tabular}

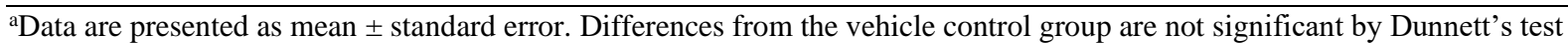
(body and tissue weights) or Dunn's test (spermatid and epididymal spermatozoal measurements).

Table D-4. Estrous Cycle Characterization for Female Mice in the Three-month Dermal Study of 5Amino-o-cresol ${ }^{\mathrm{a}}$

\section{Vehicle Control $\quad 32 \mathrm{mg} / \mathrm{kg} \quad 64 \mathrm{mg} / \mathrm{kg} \quad 128 \mathrm{mg} / \mathrm{kg}$}

\begin{tabular}{lcccc}
\hline Number weighed at necropsy & 10 & 9 & 10 & 10 \\
Necropsy body wt (g) & $37.6 \pm 1.0$ & $39.0 \pm 1.5$ & $36.4 \pm 1.7$ & $36.3 \pm 1.1$ \\
Proportion of regular cycling females ${ }^{\mathrm{b}}$ & $9 / 10$ & $9 / 9$ & $9 / 10$ & $8 / 10$ \\
Estrous cycle length (days) & $4.4 \pm 0.13$ & $4.9 \pm 0.10$ & $4.7 \pm 0.19$ & $4.8 \pm 0.24$ \\
Estrous stages (\% of cycle) & & & & \\
Diestrus & 31.9 & 38.9 & 35.6 & 36.9 \\
Proestrus & 0.0 & 0.7 & 0.0 & 0.0 \\
Estrus & 45.6 & 40.3 & 43.1 & 41.9 \\
Metestrus & 22.5 & 20.1 & 21.3 & 21.3 \\
\hline
\end{tabular}

${ }^{a}$ Necropsy body weights and estrous cycle length data are presented as mean \pm standard error. Differences from the vehicle control group are not significant by Dunnett's test (body weight) or Dunn's test (estrous cycle length). By multivariate analysis of variance, dosed females do not differ significantly from the vehicle control females in the relative length of time spent in the estrous stages. Tests for equality of transition probability matrices among all groups and between the vehicle control group and each dosed group indicated no significant differences in the probability of an altered cycle for any treated group compared to the vehicle controls.

${ }^{\mathrm{b}}$ Number of females with a regular cycle/number of females cycling. 


\section{Appendix E. Genetic Toxicology}

\section{Tables}

Table E-1. Mutagenicity of 5-Amino-o-cresol in Salmonella typhimurium...

Table E-2. Frequency of Micronuclei in Peripheral Blood Erythrocytes of Mice Following Dermal Application of 5-Amino-o-cresol for Three Months....................E-4

Table E-3. Frequency of Micronuclei in Peripheral Blood Erythrocytes of Male Mice Following Administration of 5-Amino-o-cresol by Gavage for Three Days .............E-5

Table E-4. Induction of Micronuclei in Bone Marrow Erythrocytes of Male Mice Following Administration of 5-Amino-o-cresol by Gavage for Three Days .............E-6 
Table E-1. Mutagenicity of 5-Amino-o-cresol in Salmonella typhimurium ${ }^{\text {a }}$

\begin{tabular}{|c|c|c|c|c|c|c|c|}
\hline Strain & $\begin{array}{c}\text { Dose } \\
\text { ( } \mu \mathrm{g} / \text { Plate })\end{array}$ & $\begin{array}{l}\text { Without } \\
\text { S9 }\end{array}$ & $\begin{array}{c}\text { Without } \\
\text { S9 }\end{array}$ & $\begin{array}{l}\text { With } 10 \% \\
\text { Hamster S9 }\end{array}$ & $\begin{array}{l}\text { With } 10 \% \\
\text { Hamster S9 }\end{array}$ & $\begin{array}{c}\text { With } 10 \% \\
\text { Rat S9 }\end{array}$ & $\begin{array}{c}\text { With } 10 \% \\
\text { Rat S9 }\end{array}$ \\
\hline \multirow[t]{8}{*}{ TA100 } & 0 & $89 \pm 10$ & $74 \pm 10$ & $86 \pm 3$ & $71 \pm 3$ & $83 \pm 4$ & $72 \pm 1$ \\
\hline & 33 & $83 \pm 5$ & $78 \pm 5$ & & $78 \pm 6$ & & $79 \pm 5$ \\
\hline & 100 & $80 \pm 7$ & $73 \pm 2$ & $85 \pm 9$ & $83 \pm 5$ & $76 \pm 1$ & $85 \pm 5$ \\
\hline & 333 & $94 \pm 5$ & $89 \pm 2$ & $116 \pm 7$ & $107 \pm 6$ & $94 \pm 6$ & $107 \pm 6$ \\
\hline & 1,000 & $105 \pm 3$ & $91 \pm 8$ & $213 \pm 12$ & $205 \pm 9$ & $137 \pm 10$ & $193 \pm 10$ \\
\hline & 2,000 & $112 \pm 4$ & & & & & \\
\hline & 3,333 & & Toxic & $476 \pm 29$ & $369 \pm 13$ & $210 \pm 17$ & $263 \pm 13$ \\
\hline & 6,666 & & & $166 \pm 6^{b}$ & & $317 \pm 2$ & \\
\hline Trial summary & & Negative & Negative & Positive & Positive & Positive & Positive \\
\hline Positive control $^{\mathrm{c}}$ & & $241 \pm 5$ & $337 \pm 20$ & $181 \pm 12$ & $308 \pm 4$ & $862 \pm 57$ & $502 \pm 44$ \\
\hline \multirow[t]{8}{*}{ TA97 } & 0 & $93 \pm 4$ & & $110 \pm 5$ & $131 \pm 9$ & $123 \pm 9$ & $76 \pm 4$ \\
\hline & 33 & $85 \pm 2$ & & & $129 \pm 4$ & & $94 \pm 4$ \\
\hline & 100 & $97 \pm 9$ & & $117 \pm 3$ & $125 \pm 7$ & $158 \pm 2$ & $100 \pm 5$ \\
\hline & 333 & $106 \pm 14$ & & $208 \pm 8$ & $180 \pm 10$ & $207 \pm 14$ & $128 \pm 4$ \\
\hline & 1,000 & $102 \pm 7$ & & $443 \pm 6$ & $391 \pm 19$ & $303 \pm 10$ & $303 \pm 25$ \\
\hline & 2,000 & $110 \pm 8^{b}$ & & & & & \\
\hline & 3,333 & & & $949 \pm 21$ & $824 \pm 21$ & $792 \pm 18$ & $432 \pm 31$ \\
\hline & 6,666 & & & $116 \pm 15^{\mathrm{b}}$ & & $277 \pm 62$ & \\
\hline Trial summary & & Negative & - & Positive & Positive & Positive & Positive \\
\hline Positive control & & $147 \pm 3$ & - & $548 \pm 21$ & $664 \pm 37$ & $1,343 \pm 64$ & $1,277 \pm 107^{\mathrm{d}}$ \\
\hline \multirow[t]{8}{*}{ TA98 } & 0 & $17 \pm 1$ & $16 \pm 1$ & $27 \pm 3$ & $35 \pm 2$ & $33 \pm 2$ & $27 \pm 2$ \\
\hline & 33 & $18 \pm 1$ & $21 \pm 1$ & & $34 \pm 4$ & & $39 \pm 2$ \\
\hline & 100 & $20 \pm 3$ & $17 \pm 1$ & $60 \pm 10$ & $59 \pm 6$ & $64 \pm 3$ & $55 \pm 6$ \\
\hline & 333 & $20 \pm 3$ & $22 \pm 2$ & $216 \pm 21$ & $179 \pm 17$ & $191 \pm 4$ & $180 \pm 8$ \\
\hline & 1,000 & $23 \pm 5$ & $21 \pm 1$ & $984 \pm 13$ & $824 \pm 25$ & $797 \pm 4$ & $779 \pm 20$ \\
\hline & 2,000 & $41 \pm 5$ & & & & & \\
\hline & 3,333 & & $21 \pm 3$ & $2,011 \pm 30$ & $1,703 \pm 79$ & $1,159 \pm 101$ & $1,121 \pm 82$ \\
\hline & 6,666 & & & $848 \pm 38$ & & $234 \pm 39$ & \\
\hline Trial summary & & Equivocal & Negative & Positive & Positive & Positive & Positive \\
\hline Positive control & & $218 \pm 7$ & $180 \pm 9$ & $121 \pm 2$ & $109 \pm 9$ & $262 \pm 7$ & $205 \pm 9$ \\
\hline
\end{tabular}




\begin{tabular}{lccccccc}
\hline Strain & $\begin{array}{c}\text { Dose } \\
(\boldsymbol{\mu g} / \text { Plate) }\end{array}$ & $\begin{array}{c}\text { Without } \\
\text { S9 }\end{array}$ & $\begin{array}{c}\text { Without } \\
\text { S9 }\end{array}$ & $\begin{array}{c}\text { With 10\% } \\
\text { Hamster S9 }\end{array}$ & $\begin{array}{c}\text { With 10\% } \\
\text { Hamster S9 }\end{array}$ & $\begin{array}{c}\text { With 10\% } \\
\text { Rat S9 }\end{array}$ & $\begin{array}{c}\text { With 10\% } \\
\text { Rat S9 }\end{array}$ \\
\hline TA1535 & 0 & $24 \pm 1$ & $19 \pm 3$ & $9 \pm 2$ & $13 \pm 3$ & $12 \pm 1$ & $9 \pm 1$ \\
& 33 & $24 \pm 5$ & $22 \pm 4$ & & $9 \pm 2$ & & $10 \pm 1$ \\
& 100 & $20 \pm 2$ & $19 \pm 3$ & $10 \pm 2$ & $10 \pm 1$ & $8 \pm 1$ & $8 \pm 1$ \\
& 333 & $21 \pm 3$ & $20 \pm 1$ & $13 \pm 1$ & $15 \pm 1$ & $7 \pm 0$ & $11 \pm 1$ \\
& 1,000 & $23 \pm 3$ & $14 \pm 2$ & $11 \pm 3$ & $16 \pm 3$ & $8 \pm 0$ & $8 \pm 2$ \\
& 2,000 & $15 \pm 2$ & & & & & \\
& 3,333 & & Toxic & $11 \pm 2$ & $11 \pm 1$ & $13 \pm 1$ & $11 \pm 3$ \\
Trial summary & 6,666 & & & $9 \pm 2^{\mathrm{b}}$ & & $7 \pm 1$ & \\
Positive control & & Negative & Negative & Negative & Negative & Negative & Negative \\
& & $130 \pm 5$ & $173 \pm 10$ & $35 \pm 5$ & $46 \pm 2$ & $211 \pm 12$ & $170 \pm 4$ \\
\hline
\end{tabular}

${ }^{a}$ Study was performed at BioReliance Corporation. Data are presented as revertants/plate (mean \pm standard error) from three plates. $0 \mu \mathrm{g} / \mathrm{plate}$ was the solvent control. The detailed protocol and these data are presented by Zeiger et al. ${ }^{34}$.

${ }^{\mathrm{b}}$ Slight toxicity.

'The positive controls in the absence of metabolic activation were sodium azide (TA100 and TA1535), 9-aminoacridine (TA97), and 4-nitro-o-phenylenediamine (TA98). The positive control for metabolic activation with all strains was 2-aminoanthracene.

${ }^{\mathrm{d}}$ Contamination. 
Table E-2. Frequency of Micronuclei in Peripheral Blood Erythrocytes of Mice Following Dermal Application of 5-Amino-o-cresol for Three Months ${ }^{\mathrm{a}}$

$\begin{array}{lcccc}\text { Dose }(\mathrm{mg} / \mathrm{kg}) & \begin{array}{c}\text { Number of Mice } \\ \text { with Erythrocytes } \\ \text { Scored }\end{array} & \begin{array}{c}\text { Micronucleated } \\ \text { NCEs/1,000 NCEs }\end{array} & \text { P Value }^{\mathrm{c}} & \text { PCEs }^{\mathrm{b}}(\%)\end{array}$

\begin{tabular}{lccccc}
\hline Male & & & & & \\
Ethanol $^{\mathrm{d}}$ & 0 & 5 & $1.50 \pm 0.35$ & & $3.52 \pm 0.20$ \\
5-Amino-o-cresol & 8 & 5 & $1.30 \pm 0.25$ & 0.6474 & $4.12 \pm 0.18$ \\
& 16 & 5 & $1.00 \pm 0.35$ & 0.8415 & $3.48 \pm 0.22$ \\
& 32 & 5 & $1.10 \pm 0.29$ & 0.7838 & $3.52 \pm 0.07$ \\
& 64 & 5 & $1.30 \pm 0.60$ & 0.6474 & $3.36 \pm 0.22$ \\
& 128 & 5 & $1.60 \pm 0.48$ & 0.4287 & $3.52 \pm 0.18$ \\
Female & & $\mathrm{P}=0.241^{\mathrm{e}}$ & & \\
Ethanol & & & & \\
5-Amino- $O$-cresol & 8 & 5 & $2.10 \pm 0.24$ & & $3.64 \pm 0.14$ \\
& 16 & 5 & $1.00 \pm 0.42$ & 0.9760 & $3.44 \pm 0.23$ \\
& 32 & 5 & $1.30 \pm 0.20$ & 0.9151 & $3.64 \pm 0.28$ \\
& 64 & 5 & $1.90 \pm 0.37$ & 0.6242 & $3.14 \pm 0.11$ \\
& 128 & 5 & $0.80 \pm 0.20$ & 0.9921 & $3.40 \pm 0.29$ \\
& & 5 & $1.20 \pm 0.37$ & 0.9416 & $3.56 \pm 0.08$ \\
\hline
\end{tabular}

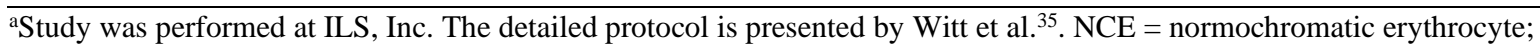

$\mathrm{PCE}=$ polychromatic erythrocyte.

${ }^{\mathrm{b}}$ Mean \pm standard error.

'Pairwise comparison with the vehicle control group; dosed group values are significant at $\mathrm{P} \leq 0.005$.

dVehicle control.

e Significance of micronucleated NCEs/1,000 NCEs tested by the one-tailed Cochran-Armitage trend test; significant at P $\leq 0.025$. 
Table E-3. Frequency of Micronuclei in Peripheral Blood Erythrocytes of Male Mice Following Administration of 5-Amino-o-cresol by Gavage for Three Days ${ }^{\mathrm{a}}$

\begin{tabular}{|c|c|c|c|c|c|c|c|}
\hline Dose (mg/kg) & $\begin{array}{l}\text { Number of } \\
\text { Mice with } \\
\text { Erythrocytes } \\
\text { Scored }\end{array}$ & $\begin{array}{c}\text { Micronucleated } \\
\text { PCEs/1,000 } \\
\text { PCEs }^{\mathrm{b}}\end{array}$ & $\begin{array}{c}\mathbf{P} \\
\text { Value }^{\mathrm{c}}\end{array}$ & $\begin{array}{c}\text { Micronucleated } \\
\text { PCEs/1,000 } \\
\text { PCEs }{ }^{\text {b }}\end{array}$ & $\begin{array}{c}\mathbf{P} \\
\text { Value }^{\mathrm{c}}\end{array}$ & $\operatorname{PCEs}^{\mathrm{b}}(\%)$ & $\begin{array}{c}\mathbf{P} \\
\text { Value }^{\mathrm{c}}\end{array}$ \\
\hline \multicolumn{8}{|l|}{ Corn oil ${ }^{\mathrm{d}}$} \\
\hline 0 & 5 & $2.44 \pm 0.18$ & & $1.59 \pm 0.05$ & & $1.695 \pm 0.06$ & \\
\hline \multicolumn{8}{|l|}{ 5-Amino-o-cresol } \\
\hline 100 & 5 & $2.41 \pm 0.19$ & 0.6870 & $1.54 \pm 0.03$ & 0.7323 & $1.720 \pm 0.07$ & 1.000 \\
\hline 200 & 5 & $2.06 \pm 0.24$ & 0.7732 & $1.52 \pm 0.05$ & 0.8137 & $1.633 \pm 0.11$ & 0.654 \\
\hline 400 & 5 & $2.34 \pm 0.16$ & 0.7669 & $1.57 \pm 0.03$ & 0.7311 & $1.418 \pm 0.07$ & 0.026 \\
\hline & & $\mathrm{P}=0.696^{\mathrm{e}}$ & & $\mathrm{P}=0.562$ & & $\mathrm{P}=0.009$ & \\
\hline
\end{tabular}

Cyclophosphamide ${ }^{\mathrm{f}}$

$$
\begin{array}{llllllll}
50 & 5 & 28.0 \pm 1.09 & 0.0000 & 1.91 \pm 0.03 & 0.0000 & 0.149 \pm 0.01 & 0.000
\end{array}
$$

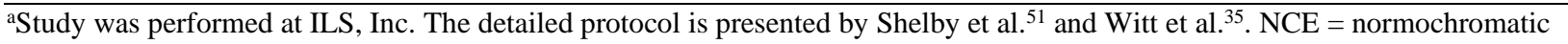
erythrocyte; $\mathrm{PCE}=$ polychromatic erythrocyte.

${ }^{b}$ Mean \pm standard error.

'Pairwise comparison with the vehicle control group; significant at $\mathrm{P} \leq 0.025$ by Williams' test.

${ }^{\mathrm{d}}$ Vehicle control.

${ }^{\mathrm{e}}$ Dose-related trend; significant at $\mathrm{P} \leq 0.025$ by linear regression.

fPositive control. 
Table E-4. Induction of Micronuclei in Bone Marrow Erythrocytes of Male Mice Following Administration of 5-Amino-o-cresol by Gavage for Three Days ${ }^{\mathrm{a}}$

\begin{tabular}{|c|c|c|c|c|c|}
\hline & Dose (mg/kg) & $\begin{array}{l}\text { Number of Mice } \\
\text { with Erythrocytes } \\
\text { Scored }\end{array}$ & $\begin{array}{c}\text { Micronucleated } \\
\text { PCEs/1,000 PCEs }\end{array}$ & P Value ${ }^{c}$ & $\operatorname{PCEs}^{\mathrm{b}}(\%)$ \\
\hline \multicolumn{6}{|l|}{ Trial 1} \\
\hline Corn oil $^{\mathrm{d}}$ & 0 & 5 & $1.10 \pm 0.51$ & & $68.80 \pm 1.55$ \\
\hline \multirow[t]{4}{*}{ 5-Amino- $O$-cresol } & 100 & 5 & $2.78 \pm 0.60$ & 0.0039 & $62.30 \pm 4.39$ \\
\hline & 200 & 5 & $1.60 \pm 0.56$ & 0.1678 & $65.20 \pm 2.08$ \\
\hline & 400 & 5 & $2.20 \pm 0.46$ & 0.0277 & $66.50 \pm 2.95$ \\
\hline & & & $\mathrm{P}=0.137^{\mathrm{e}}$ & & \\
\hline Cyclophosphamide $^{\mathrm{f}}$ & 50 & & $39.90 \pm 4.46$ & 0.0000 & $27.30 \pm 2.31$ \\
\hline \multicolumn{6}{|l|}{ Trial 2} \\
\hline Corn oil & 0 & 5 & $3.00 \pm 0.74$ & & $63.10 \pm 2.51$ \\
\hline \multirow[t]{5}{*}{ 5-Amino- $O$-cresol } & 50 & 5 & $2.10 \pm 0.58$ & 0.8965 & $57.10 \pm 4.15$ \\
\hline & 100 & 5 & $2.90 \pm 0.48$ & 0.5519 & $64.60 \pm 3.07$ \\
\hline & 200 & 5 & $2.10 \pm 0.37$ & 0.8965 & $61.40 \pm 4.79$ \\
\hline & 400 & 4 & $2.25 \pm 0.32$ & 0.8339 & $64.75 \pm 3.71$ \\
\hline & & & $P=0.805$ & & \\
\hline Cyclophosphamide & 50 & & $42.50 \pm 1.54$ & 0.0000 & $26.00 \pm 3.84$ \\
\hline \multicolumn{6}{|c|}{$\begin{array}{l}\text { a Study was performed at ILS, Inc. The detailed protocol and these data are presented by Witt et al. }{ }^{35} \text {. PCE }=\text { polychromatic } \\
\text { erythrocyte. } \\
\text { b Mean } \pm \text { standard error. } \\
\text { 'Pairwise comparison with the vehicle control group; dosed group values are significant at } \mathrm{P} \leq 0.008 \text { (trial } 1 \text { ) or } \mathrm{P} \leq 0.006 \text { (trial } \\
\text { 2); positive control values are significant at } \mathrm{P} \leq 0.025 \text {. } \\
\text { dVehicle control. }\end{array}$} \\
\hline
\end{tabular}




\section{Appendix F. Chemical Characterization and Dose Formulation Studies}

\section{Table of Contents}

F.1. Procurement and Characterization.

F-2

F.2. Preparation and Analysis of Dose Formulations

\section{Tables}

Table F-1. Gas Chromatography Systems Used in the Three-month Dermal Studies of 5-Amino-o-cresol

Table F-2. High-Performance Liquid Chromatography Systems Used in the Three-month Dermal Studies of 5-Amino- $O$-cresol

Table F-3. Preparation and Storage of Dose Formulations in the Three-month Dermal Studies of 5-Amino- $O$-cresol

Table F-4. Results of Analyses of Dose Formulations Administered to Rats and Mice in the Three-month Dermal Studies of 5-Amino-o-cresol.

\section{Figures}

Figure F-1. Infrared Absorption Spectrum of 5-Amino- $O$-cresol F-8

Figure F-2. Proton Nuclear Magnetic Resonance Spectrum of 5-Amino- $O$-cresol F-8

Figure F-3. Electron Ionization Mass Spectrum of 5-Amino-o-cresol F-9 


\section{F.1. Procurement and Characterization}

\section{F.1.1. 5-Amino-o-cresol}

5-Amino-o-cresol was obtained from Fluka Chemical Company (Buchs, Switzerland) in one lot (385913/1) that was used in the 3-month dermal studies. Identity, purity, and stability analyses were conducted by the analytical chemistry laboratory at Research Triangle Institute (Research Triangle Park, NC) and the study laboratory at Battelle Columbus Operations (Columbus, $\mathrm{OH}$ ). Karl Fischer titration was performed by Galbraith Laboratories (Knoxville, TN). Reports on analyses performed in support of the 5-amino- $O$-cresol studies are on file at the National Institute of Environmental Health Sciences.

The test chemical, a beige powder, was identified as 5-amino- $o$-cresol by the analytical chemistry laboratory and the study laboratory using infrared (IR) spectroscopy; the analytical chemistry laboratory also used proton nuclear magnetic resonance (NMR) spectroscopy, gas chromatography (GC) with mass spectrometry, and melting point determination. All spectra were consistent with the structure of 5-amino- $O$-cresol, and the mass spectrum and IR spectrum were consistent with the literature spectra ${ }^{63}$. Representative IR, NMR, and electron ionization mass spectra are presented in Figure F-1, Figure F-2, and Figure F-3, respectively. The melting point was consistent with the melting point reported on the manufacturer's Certificate of Analysis.

For lot 385913/1, Karl Fischer titration was used to determine the water content of the test chemical. The purity was determined by the analytical chemistry laboratory using GC with flame ionization detection (FID) by systems A and B (Table F-1), and high-performance liquid chromatography (HPLC) with ultraviolet light (UV) detection by system A (Table F-2).

Karl Fischer titration indicated a range of $0.14 \%$ to $0.48 \%$ water. GC/FID analysis by system A (Table F-1) indicated one major peak with three impurities greater than $0.1 \%$ of the total peak area, with a combined total of $0.80 \%$ of the total peak area. GC/FID analysis by system B (Table F-1) indicated one major peak and one impurity with an area of $0.37 \%$ relative to the total peak area. HPLC/UV by system A (Table F-2) indicated one major peak and no impurities. The overall purity of lot $385913 / 1$ was estimated to be greater than $99 \%$.

Stability studies of the test chemical were performed by the analytical chemistry laboratory using GC/FID by system C (Table F-1). Stability was confirmed for at least 2 weeks for samples stored in sealed amber glass vials at temperatures up to $25^{\circ} \mathrm{C}$. To ensure stability, the test chemical was stored in sealed amber glass vials at room temperature $\left(\sim 25^{\circ} \mathrm{C}\right)$. Periodic reanalyses of the test chemical were performed by the study laboratory using HPLC/UV by system B (Table F-2); no degradation was observed.

\section{F.1.2. Ethanol}

USP-grade 95\% ethanol was obtained from Spectrum Chemical and Laboratory Products (Gardena, CA) in one lot (UO0008) that was used as the vehicle in the 3-month dermal studies. Lot UO0008, a clear liquid, was identified as ethanol by the study laboratory using IR spectroscopy; the IR spectrum was consistent with a literature spectrum of ethanol ${ }^{64}$. 
The purity of lot UO0008 was determined by the study laboratory using GC/FID by systems D and $\mathrm{E}$ (Table F-1). Analysis by system D indicated there were no impurities greater than $0.1 \%$ of the total peak area; analysis by system $\mathrm{E}$ indicated no benzene in the vehicle. The overall purity was determined to be greater than $99 \%$.

To ensure stability, lot UO0008 of the vehicle was stored at ambient conditions. Reanalyses of the vehicle were performed by the study laboratory using GC/FID by system D, and no degradation was observed.

\section{F.2. Preparation and Analysis of Dose Formulations}

The dose formulations were prepared by mixing 5 -amino-o-cresol with $95 \%$ ethanol to give the required concentrations (Table F-3). The dose formulations were stored in amber glass bottles sealed with Teflon ${ }^{\circledR}$-lined lids at room temperature $\left(\sim 25^{\circ} \mathrm{C}\right)$ and used within 35 days. The dose formulations were prepared four times during the 3 -month studies.

Stability studies of the $4 \mathrm{mg} / \mathrm{mL}$ dose formulation were performed by the analytical chemistry laboratory with HPLC/UV using system B (Table F-2). Stability was confirmed for at least 42 days for dose formulations stored in glass containers sealed with Teflon ${ }^{\circledR}$-lined lids, protected from light, at temperatures up to $25^{\circ} \mathrm{C}$, and for 3 hours under simulated animal room conditions. A dose simulation (skin paint) stability study was also performed using HPLC/UV by system B. Samples of the $4 \mathrm{mg} / \mathrm{mL}$ dose formulation were placed in partially covered Teflon ${ }^{\circledR}$ Petri dishes under a hood; stability was confirmed for at least 5 hours.

The dose formulations were analyzed three times by the study laboratory using HPLC/UV by system B. All 15 dose formulations analyzed for rats and mice were within 10\% of the target concentrations (Table F-4). Animal room samples of these dose formulations were also analyzed; all 15 samples for rats and all 15 samples for mice were within $10 \%$ of the target concentrations. 
Table F-1. Gas Chromatography Systems Used in the Three-month Dermal Studies of 5-Amino-o-cresol ${ }^{\text {a }}$

\begin{tabular}{|c|c|c|c|}
\hline Detection System & Column & Carrier Gas & $\begin{array}{c}\text { Oven Temperature } \\
\text { Program }\end{array}$ \\
\hline
\end{tabular}

\section{System A}

Flame ionization

Equity $^{\circledR}-5,30 \mathrm{~m} \times 0.32 \mathrm{~mm}$, $0.25 \mu \mathrm{m}$ film (Supelco, Inc., Bellefonte, PA)

Helium at $1.2 \mathrm{~mL} / \mathrm{minute}$

$50^{\circ} \mathrm{C}$ for 15 minutes, then $10^{\circ} \mathrm{C} /$ minute to $250^{\circ} \mathrm{C}$, held for 25 minutes

System B

Flame ionization

DBTM-624, $30 \mathrm{~m} \times 0.548 \mathrm{~mm}$, $3.0 \mu \mathrm{m}$ film (J\&W Scientific, Folsom, CA)

Helium at $3.9 \mathrm{~mL} /$ minute

$40^{\circ} \mathrm{C}$ for 10 minutes, then $5^{\circ} \mathrm{C} /$ minute to $200^{\circ} \mathrm{C}$, held for 18 minutes

System C

Flame ionization

Equity ${ }^{\circledR}-5,30 \mathrm{~m} \times 0.32 \mathrm{~mm}$, $0.25 \mu \mathrm{m}$ film (Supelco, Inc.)

Helium at $1.0 \mathrm{~mL} /$ minute

$40^{\circ} \mathrm{C}$ for 10 minutes, then $5^{\circ} \mathrm{C} /$ minute to $200^{\circ} \mathrm{C}$, held for 18 minutes

\section{System D}

Flame ionization

DBTM_WAX, $30 \mathrm{~m} \times 0.53 \mathrm{~mm}$, $1.0 \mu \mathrm{m}$ film (J\&W Scientific)

Helium at $10 \mathrm{~mL} /$ minute

$40^{\circ} \mathrm{C}$ for 5 minutes, then $10^{\circ} \mathrm{C} /$ minute to $220^{\circ} \mathrm{C}$, held for 5 minutes

\section{System E}

Flame ionization

Rtx $^{\circledR}-5,30 \mathrm{~m} \times 0.53 \mathrm{~mm}, 1.5 \mu \mathrm{m} \quad$ Helium at $10 \mathrm{~mL} /$ minute film (Restek, Bellefonte, PA) $40^{\circ} \mathrm{C}$ for 3 minutes, then $10^{\circ} \mathrm{C} /$ minute to $200^{\circ} \mathrm{C}$, held for 3 minutes

The gas chromatographs were manufactured by Hewlett-Packard (Palo Alto, CA).

Table F-2. High-Performance Liquid Chromatography Systems Used in the Three-month Dermal Studies of 5-Amino-o-cresol ${ }^{\mathrm{a}}$
Detection System
Column
Solvent System

\section{System A}

Ultraviolet $(210 \mathrm{~nm})$ light Atlantis ${ }^{\mathrm{TM}} \mathrm{dC}_{18}, 15 \mathrm{~cm} \times 3.9 \mathrm{~mm}, 20 \mathrm{mM} \mathrm{NH}_{4} \mathrm{H}_{2} \mathrm{PO}_{4}$ buffer $(\mathrm{pH} 3.0)$ :methanol $5 \mu \mathrm{m}$ film (Waters-Millipore, Milford, MA) (95:5); isocratic, flow rate $1.0 \mathrm{~mL} /$ minute

\section{System B}

Ultraviolet $(210 \mathrm{~nm})$ light ZORBAX Eclipse XDBTM $-\mathrm{C}_{8}$, $250 \mathrm{~mm} \times 4.6 \mathrm{~mm}, 5.0 \mu \mathrm{m}$ film (Agilent Technologies, Inc., Santa Clara, CA)

A) 10:90 methanol:water with $20 \mathrm{mM} \mathrm{NH}_{4} \mathrm{H}_{2} \mathrm{PO}_{4}$ buffer adjusted to $\mathrm{pH} 2.5$ with $\mathrm{H}_{3} \mathrm{PO}_{4}$ B) $90: 10$ methanol:water with $20 \mathrm{mM} \mathrm{NH}_{4} \mathrm{H}_{2} \mathrm{PO}_{4}$ buffer adjusted to $\mathrm{pH} 2.5$ with $\mathrm{H}_{3} \mathrm{PO}_{4}$; $100 \%$ A for 2 minutes, then linear gradient to $50 \%$ A:50\% B in 10 minutes, held for 2 minutes, then linear gradient to $100 \% \mathrm{~A}$ in 2 minutes, held 13 minutes; flow rate $1.0 \mathrm{~mL} /$ minute

\footnotetext{
aThe high-performance liquid chromatographs were manufactured by Waters Corporation (Milford, MA).
} 
Table F-3. Preparation and Storage of Dose Formulations in the Three-month Dermal Studies of 5-Amino-o-cresol

\section{Three-month Studies}

\section{Preparation}

Dose formulations were prepared by weighing the appropriate amount of 5-amino-o-cresol into a beaker, then transferring with three 95\% ethanol rinses to a calibrated mixing container half-filled with $95 \%$ ethanol, diluted to final volume, stirred on a stirplate for 5 minutes or until dissolved; if necessary, sonicated to get into solution.

\section{Chemical Lot Number}

$385913 / 1$

\section{Maximum Storage Time}

35 days

\section{Storage Conditions}

The dose formulations were stored in amber glass vials sealed with Teflon ${ }^{\circledR}$-lined lids at $25^{\circ} \mathrm{C}$.

Study Laboratory

Battelle Columbus Operations (Columbus, $\mathrm{OH}$ ) 
Table F-4. Results of Analyses of Dose Formulations Administered to Rats and Mice in the Threemonth Dermal Studies of 5-Amino-o-cresol

\begin{tabular}{|c|c|c|c|c|}
\hline Date Prepared & Date Analyzed & $\begin{array}{c}\text { Target } \\
\text { Concentration } \\
(\mathbf{m g} / \mathbf{m L})\end{array}$ & $\begin{array}{l}\text { Determined } \\
\text { Concentration }^{\mathrm{a}} \\
(\mathrm{mg} / \mathrm{mL})\end{array}$ & $\begin{array}{c}\text { Difference } \\
\text { from Target } \\
(\%)\end{array}$ \\
\hline \multicolumn{5}{|l|}{ Rats } \\
\hline \multirow[t]{10}{*}{ April 26, 2006} & May 1-2, 2006 & 4 & 3.889 & -3 \\
\hline & & 8 & 7.806 & -2 \\
\hline & & 16 & 15.65 & -2 \\
\hline & & 32 & 31.05 & -3 \\
\hline & & 64 & 60.88 & -5 \\
\hline & May 31-June 1, 2006 & 4 & 3.894 & -3 \\
\hline & & 8 & 7.843 & -2 \\
\hline & & 16 & 15.61 & -2 \\
\hline & & 32 & 31.44 & -2 \\
\hline & & 64 & 61.68 & -4 \\
\hline \multirow[t]{4}{*}{ May 19, 2006} & May 22-23, 2006 & 4 & 3.871 & -3 \\
\hline & & 8 & 7.593 & -5 \\
\hline & & 16 & 15.20 & -5 \\
\hline & & 32 & 29.76 & -7 \\
\hline \multirow[t]{6}{*}{ May 24, 2006} & May 24, 2006 & 64 & 63.94 & 0 \\
\hline & June $26-27,2006^{\mathrm{b}}$ & 4 & 3.914 & -2 \\
\hline & & 8 & 7.834 & -2 \\
\hline & & 16 & 15.63 & -2 \\
\hline & & 32 & 31.15 & -3 \\
\hline & & 64 & 61.90 & -3 \\
\hline \multirow[t]{10}{*}{ July 11, 2006} & July 12-13, 2006 & 4 & 3.784 & -5 \\
\hline & & 8 & 7.401 & -8 \\
\hline & & 16 & 15.23 & -5 \\
\hline & & 32 & 29.13 & -9 \\
\hline & & 64 & 59.37 & -7 \\
\hline & September $6-7,2006^{\mathrm{b}}$ & 4 & 3.814 & -5 \\
\hline & & 8 & 7.660 & -4 \\
\hline & & 16 & 15.48 & -3 \\
\hline & & 32 & 29.63 & -7 \\
\hline & & 64 & 61.41 & -4 \\
\hline
\end{tabular}




\begin{tabular}{|c|c|c|c|c|}
\hline Date Prepared & Date Analyzed & $\begin{array}{c}\text { Target } \\
\text { Concentration } \\
(\mathrm{mg} / \mathrm{mL})\end{array}$ & $\begin{array}{c}\text { Determined } \\
\text { Concentration }^{\mathrm{a}} \\
(\mathrm{mg} / \mathrm{mL})\end{array}$ & $\begin{array}{c}\text { Difference } \\
\text { from Target } \\
(\%)\end{array}$ \\
\hline \multicolumn{5}{|l|}{ Mice } \\
\hline \multirow[t]{10}{*}{ April 26, 2006} & May 1-2, 2006 & 4 & 3.889 & -3 \\
\hline & & 8 & 7.806 & -2 \\
\hline & & 16 & 15.65 & -2 \\
\hline & & 32 & 31.05 & -3 \\
\hline & & 64 & 60.88 & -5 \\
\hline & May $31-$ June $1,2006^{c}$ & 4 & 3.871 & -3 \\
\hline & & 8 & 7.715 & -4 \\
\hline & & 16 & 15.57 & -3 \\
\hline & & 32 & 31.52 & -2 \\
\hline & & 64 & 61.23 & -4 \\
\hline \multirow[t]{4}{*}{ May 19, 2006} & May 22-23, 2006 & 4 & 3.871 & -3 \\
\hline & & 8 & 7.593 & -5 \\
\hline & & 16 & 15.20 & -5 \\
\hline & & 32 & 29.76 & -7 \\
\hline May 24, 2006 & May 24, 2006 & 64 & 63.94 & 0 \\
\hline \multirow[t]{5}{*}{ May 19, 2006} & June $26-27,2006^{c}$ & 4 & 3.854 & -4 \\
\hline & & 8 & 7.759 & -3 \\
\hline & & 16 & 15.57 & -3 \\
\hline & & 32 & 30.13 & -6 \\
\hline & & 64 & 61.15 & -5 \\
\hline \multirow[t]{10}{*}{ July 11, 2006} & July 12-13, 2006 & 4 & 3.784 & -5 \\
\hline & & 8 & 7.401 & -8 \\
\hline & & 16 & 15.23 & -5 \\
\hline & & 32 & 29.13 & -9 \\
\hline & & 64 & 59.37 & -7 \\
\hline & August $11-12,2006^{\mathrm{c}}$ & 4 & 3.802 & -5 \\
\hline & & 8 & 7.764 & -3 \\
\hline & & 16 & 15.75 & -2 \\
\hline & & 32 & 31.33 & -2 \\
\hline & & 64 & 62.86 & -2 \\
\hline
\end{tabular}

${ }^{\mathrm{a}}$ Results of duplicate analyses. For rats, dosing volume $=0.5 \mathrm{~mL} / \mathrm{kg} ; 4 \mathrm{mg} / \mathrm{mL}=2 \mathrm{mg} / \mathrm{kg}, 8 \mathrm{mg} / \mathrm{mL}=4 \mathrm{mg} / \mathrm{kg}$,

$16 \mathrm{mg} / \mathrm{mL}=8 \mathrm{mg} / \mathrm{kg}, 32 \mathrm{mg} / \mathrm{mL}=16 \mathrm{mg} / \mathrm{kg}, 64 \mathrm{mg} / \mathrm{mL}=32 \mathrm{mg} / \mathrm{kg}$. For mice, dosing volume $=2 \mathrm{~mL} / \mathrm{kg} ; 4 \mathrm{mg} / \mathrm{mL}=8 \mathrm{mg} / \mathrm{kg}$, $8 \mathrm{mg} / \mathrm{mL}=16 \mathrm{mg} / \mathrm{kg}, 16 \mathrm{mg} / \mathrm{mL}=32 \mathrm{mg} / \mathrm{kg}, 32 \mathrm{mg} / \mathrm{mL}=64 \mathrm{mg} / \mathrm{kg}, 64 \mathrm{mg} / \mathrm{mL}=128 \mathrm{mg} / \mathrm{kg}$.

${ }^{\mathrm{b}}$ Animal room samples for rats.

${ }^{\mathrm{c} A n i m a l}$ room samples for mice. 


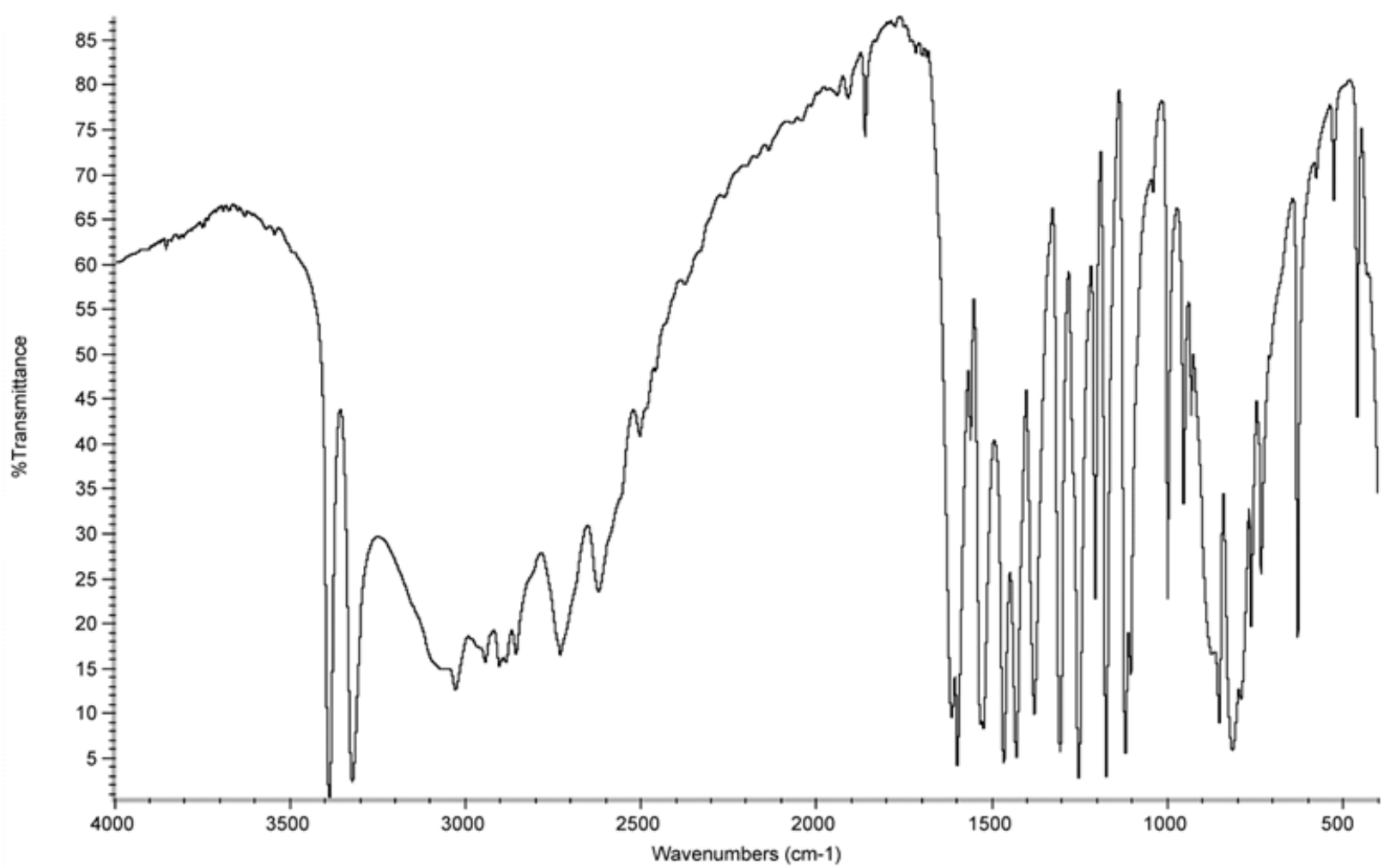

Figure F-1. Infrared Absorption Spectrum of 5-Amino-o-cresol

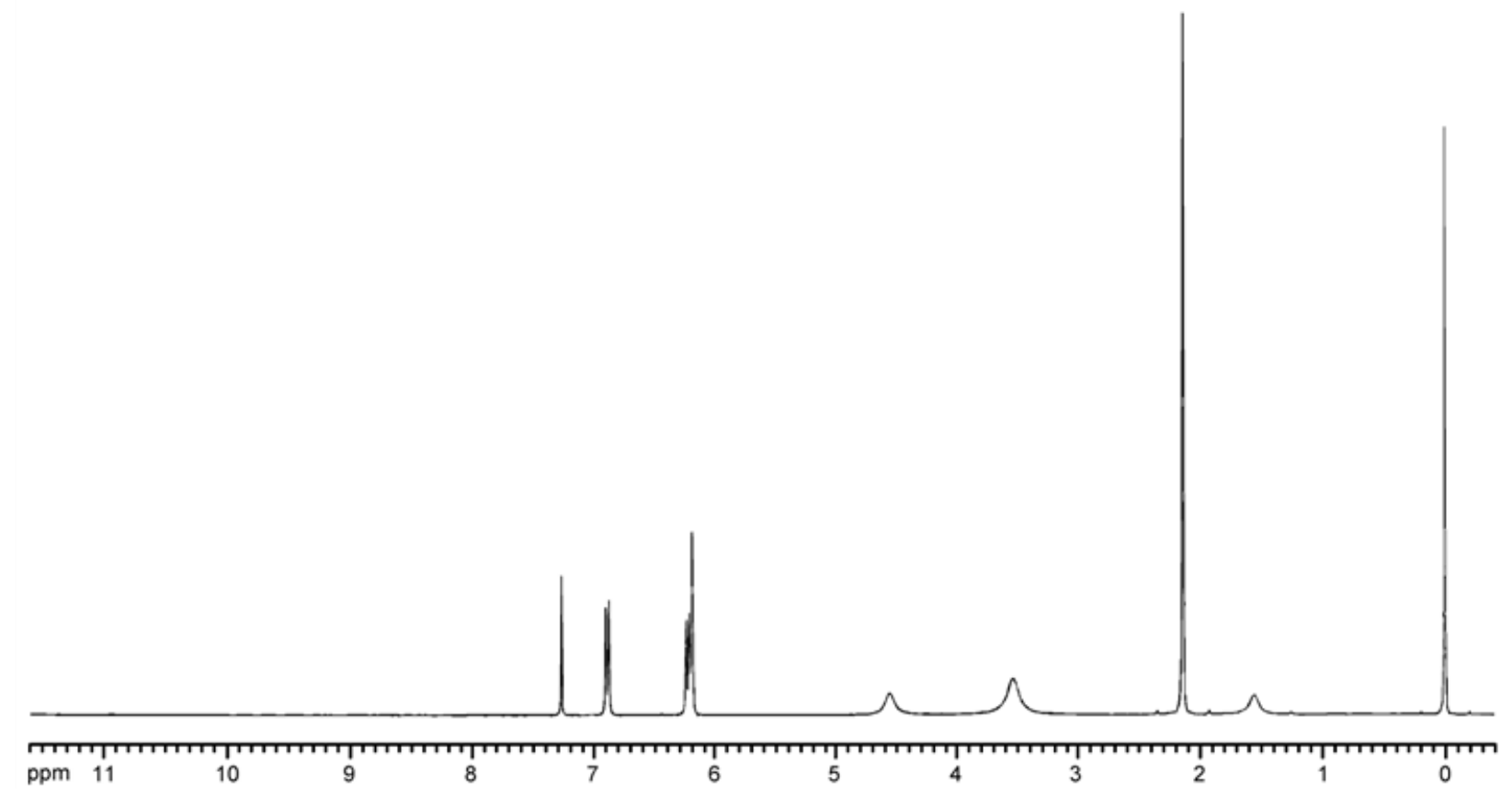

Figure F-2. Proton Nuclear Magnetic Resonance Spectrum of 5-Amino-o-cresol 
5-Amino-o-cresol, NTP TOX 89

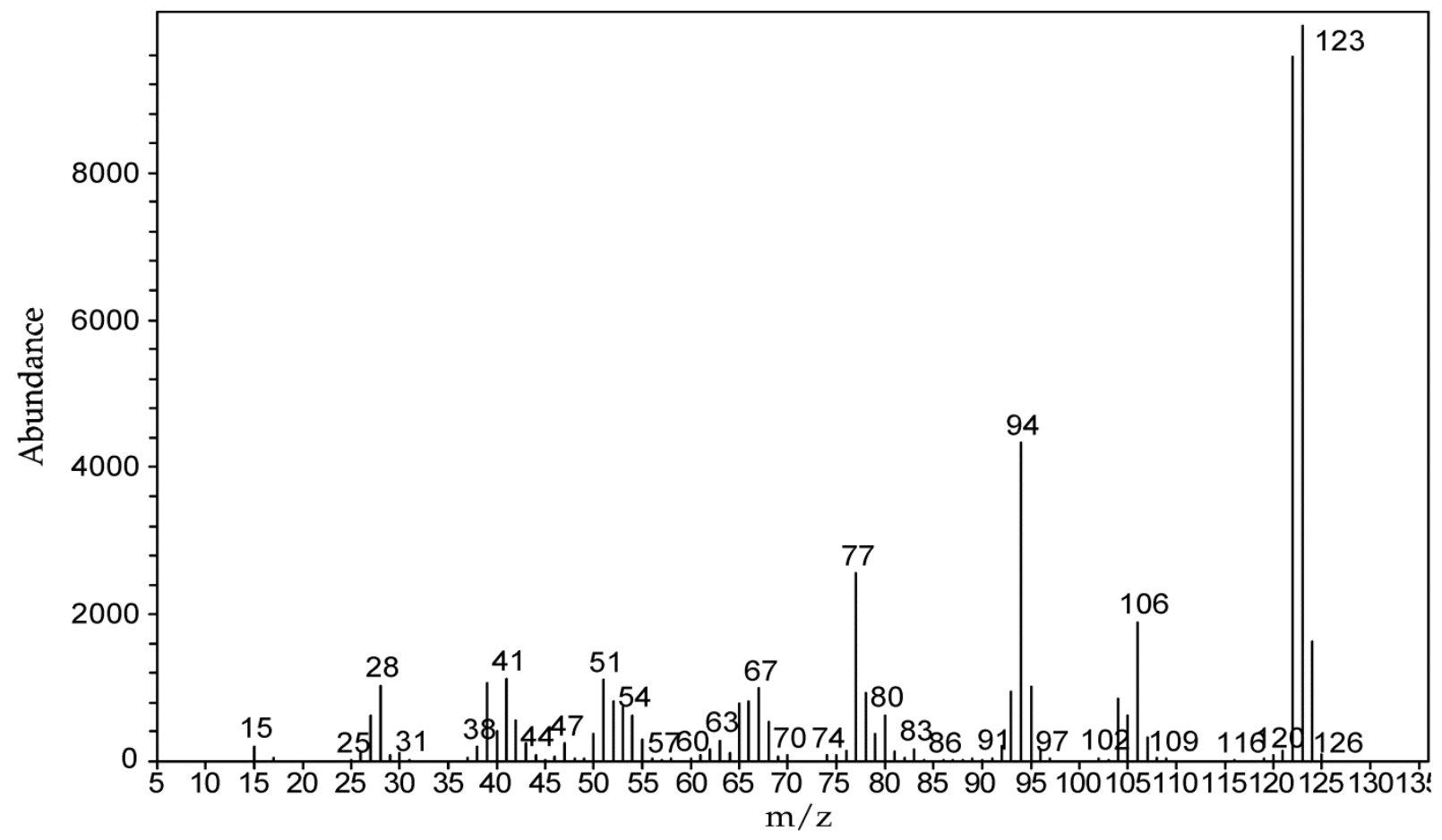

Figure F-3. Electron Ionization Mass Spectrum of 5-Amino-o-cresol 


\section{Appendix G. Ingredients, Nutrient Composition, and Contaminant Levels in NTP-2000 Rat and Mouse Ration}

\section{Tables}

Table G-1. Ingredients of NTP-2000 Rat and Mouse Ration ..... G-2

Table G-2. Vitamins and Minerals in NTP-2000 Rat and Mouse Ration G-2

Table G-3. Nutrient Composition of NTP-2000 Rat and Mouse Ration G-3

Table G-4. Contaminant Levels in NTP-2000 Rat and Mouse Ration G-5 
Table G-1. Ingredients of NTP-2000 Rat and Mouse Ration

\section{Ingredients}

Ground hard winter wheat

Ground \#2 yellow shelled corn

Wheat middlings

Oat hulls

Alfalfa meal (dehydrated, $17 \%$ protein)

Purified cellulose

Soybean meal (49\% protein)

Fish meal (60\% protein)

Corn oil (without preservatives)

Soy oil (without preservatives)

Dried brewer's yeast

Calcium carbonate (USP)

Vitamin premix ${ }^{\mathrm{a}}$

Mineral premix ${ }^{\mathrm{b}}$

Calcium phosphate, dibasic (USP)

Sodium chloride

Choline chloride (70\% choline)

Methionine

${ }^{\mathrm{a} W h e a t ~ m i d d l i n g s ~ a s ~ c a r r i e r . ~}$

${ }^{\mathrm{b}}$ Calcium carbonate as carrier.

\section{Percent by Weight}

22.26

22.18

15.0

8.5

7.5

5.5

5.0

4.0

3.0

3.0

1.0

0.9

0.5

0.5

0.4

0.3

0.26

0.2

Table G-2. Vitamins and Minerals in NTP-2000 Rat and Mouse Ration ${ }^{a}$

\begin{tabular}{lcc}
\hline & Amount & Source \\
\hline Vitamins & & \\
$\mathrm{A}$ & $4,000 \mathrm{IU}$ & Stabilized vitamin A palmitate or acetate \\
$\mathrm{D}$ & $1,000 \mathrm{IU}$ & D-activated animal sterol \\
$\mathrm{K}$ & $1.0 \mathrm{mg}$ & Menadione sodium bisulfite complex \\
$\alpha$-Tocopheryl acetate & $100 \mathrm{IU}$ & - \\
Niacin & $23 \mathrm{mg}$ & - \\
Folic acid & $1.1 \mathrm{mg}$ & - \\
$d$-Pantothenic acid & $10 \mathrm{mg}$ & $d$-Calcium pantothenate \\
Riboflavin & $3.3 \mathrm{mg}$ & - \\
Thiamine & $4 \mathrm{mg}$ & Thiamine mononitrate \\
B $_{12}$ & $52 \mu \mathrm{g}$ & - \\
Pyridoxine & $6.3 \mathrm{mg}$ & Pyridoxine hydrochloride \\
Biotin & $0.2 \mathrm{mg}$ & $d$-Biotin \\
\hline
\end{tabular}




\begin{tabular}{lcl}
\hline & Amount & \multicolumn{1}{c}{ Source } \\
\hline Minerals & & \\
Magnesium & $514 \mathrm{mg}$ & Magnesium oxide \\
Iron & $35 \mathrm{mg}$ & Iron sulfate \\
Zinc & $12 \mathrm{mg}$ & Zinc oxide \\
Manganese & $10 \mathrm{mg}$ & Manganese oxide \\
Copper & $2.0 \mathrm{mg}$ & Copper sulfate \\
Iodine & $0.2 \mathrm{mg}$ & Calcium iodate \\
Chromium & $0.2 \mathrm{mg}$ & Chromium acetate \\
\hline
\end{tabular}

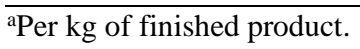

Table G-3. Nutrient Composition of NTP-2000 Rat and Mouse Ration

\begin{tabular}{|c|c|c|c|}
\hline Nutrient & $\begin{array}{c}\text { Mean } \pm \text { Standard } \\
\text { Deviation }\end{array}$ & Range & Number of Samples \\
\hline Protein ( $\%$ by weight) & $14.1 \pm 0.43$ & $13.5-14.7$ & 5 \\
\hline Crude fat ( $\%$ by weight) & $8.4 \pm 0.37$ & $8.0-8.9$ & 5 \\
\hline Crude fiber ( $\%$ by weight) & $9.1 \pm 0.4$ & $8.6-9.7$ & 5 \\
\hline Ash (\% by weight) & $4.9 \pm 0.15$ & $4.7-5.0$ & 5 \\
\hline \multicolumn{4}{|c|}{ Amino Acids ( $\%$ of total diet) } \\
\hline Arginine & $0.783 \pm 0.070$ & $0.670-0.970$ & 22 \\
\hline Cystine & $0.220 \pm 0.024$ & $0.150-0.250$ & 22 \\
\hline Glycine & $0.701 \pm 0.041$ & $0.620-0.800$ & 22 \\
\hline Histidine & $0.352 \pm 0.077$ & $0.270-0.680$ & 22 \\
\hline Isoleucine & $0.546 \pm 0.044$ & $0.430-0.660$ & 22 \\
\hline Leucine & $1.095 \pm 0.067$ & $0.960-1.240$ & 22 \\
\hline Lysine & $0.711 \pm 0.114$ & $0.310-0.860$ & 22 \\
\hline Methionine & $0.409 \pm 0.046$ & $0.260-0.490$ & 22 \\
\hline Phenylalanine & $0.628 \pm 0.040$ & $0.540-0.720$ & 22 \\
\hline Threonine & $0.505 \pm 0.043$ & $0.430-0.610$ & 22 \\
\hline Tryptophan & $0.150 \pm 0.028$ & $0.110-0.200$ & 22 \\
\hline Tyrosine & $0.401 \pm 0.061$ & $0.280-0.540$ & 22 \\
\hline Valine & $0.665 \pm 0.043$ & $0.550-0.730$ & 22 \\
\hline \multicolumn{4}{|c|}{ Essential Fatty Acids (\% of total diet) } \\
\hline Linoleic & $3.95 \pm 0.259$ & $3.49-4.55$ & 22 \\
\hline Linolenic & $0.30 \pm 0.032$ & $0.21-0.35$ & 22 \\
\hline \multicolumn{4}{|l|}{ Vitamins } \\
\hline Vitamin A (IU/kg) & $3,226 \pm 57$ & $2,340-3,820$ & 5 \\
\hline Vitamin D (IU/kg) & $1,000^{\mathrm{a}}$ & - & - \\
\hline
\end{tabular}




\begin{tabular}{|c|c|c|c|}
\hline Nutrient & $\begin{array}{c}\text { Mean } \pm \text { Standard } \\
\text { Deviation }\end{array}$ & Range & Number of Samples \\
\hline$\alpha$-Tocopherol (ppm) & $80.6 \pm 22.03$ & $27.0-124.0$ & 22 \\
\hline Thiamine (ppm) $)^{\mathrm{b}}$ & $7.1 \pm 0.66$ & $6.5-8.1$ & 5 \\
\hline Riboflavin (ppm) & $7.6 \pm 2.89$ & $4.20-17.50$ & 22 \\
\hline Niacin (ppm) & $78.9 \pm 9.08$ & $66.4-98.2$ & 22 \\
\hline Pantothenic acid (ppm) & $26.9 \pm 12.63$ & $17.4-81.0$ & 22 \\
\hline Pyridoxine (ppm) ${ }^{\mathrm{b}}$ & $9.54 \pm 1.99$ & $6.44-13.7$ & 22 \\
\hline Folic acid (ppm) & $1.62 \pm 0.48$ & $1.15-3.27$ & 22 \\
\hline Biotin (ppm) & $0.32 \pm 0.10$ & $0.20-0.704$ & 22 \\
\hline Vitamin $B_{12}(p p b)$ & $53.6 \pm 39.6$ & $18.3-174.0$ & 22 \\
\hline Choline (ppm) $)^{\mathrm{b}}$ & $2,846 \pm 485$ & $1,820-3,790$ & 22 \\
\hline \multicolumn{4}{|l|}{ Minerals } \\
\hline Calcium (\%) & $0.971 \pm 0.050$ & $0.920-1.030$ & 5 \\
\hline Phosphorus (\%) & $0.547 \pm 0.020$ & $0.515-0.566$ & 5 \\
\hline Potassium (\%) & $0.666 \pm 0.030$ & $0.626-0.733$ & 22 \\
\hline Chloride (\%) & $0.386 \pm 0.039$ & $0.300-0.474$ & 22 \\
\hline Sodium (\%) & $0.189 \pm 0.016$ & $0.160-0.222$ & 22 \\
\hline Magnesium (\%) & $0.216 \pm 0.062$ & $0.185-0.490$ & 22 \\
\hline Sulfur $(\%)$ & $0.170 \pm 0.029$ & $0.116-0.209$ & 14 \\
\hline Iron (ppm) & $186 \pm 39.2$ & $135-311$ & 22 \\
\hline Manganese (ppm) & $51.4 \pm 10.28$ & $21.0-73.1$ & 22 \\
\hline Zinc (ppm) & $53.4 \pm 8.46$ & $43.3-78.5$ & 22 \\
\hline Copper (ppm) & $7.01 \pm 2.562$ & $3.21-16.3$ & 22 \\
\hline Iodine (ppm) & $0.503 \pm 0.206$ & $0.158-0.972$ & 22 \\
\hline Chromium (ppm) & $0.694 \pm 0.276$ & $0.330-1.380$ & 22 \\
\hline Cobalt (ppm) & $0.256 \pm 0.164$ & $0.098-0.864$ & 20 \\
\hline
\end{tabular}

aFrom formulation.

${ }^{\mathrm{b}}$ As hydrochloride (thiamine and pyridoxine) or chloride (choline). 
Table G-4. Contaminant Levels in NTP-2000 Rat and Mouse Ration ${ }^{\text {a }}$

\begin{tabular}{|c|c|c|c|}
\hline & Mean \pm Standard Deviation & Range & Number of Samples \\
\hline \multicolumn{4}{|l|}{ Contaminants } \\
\hline Arsenic (ppm) & $0.20 \pm 0.040$ & $0.16-0.26$ & 5 \\
\hline Cadmium (ppm) & $0.05 \pm 0.006$ & $0.04-0.05$ & 5 \\
\hline Lead (ppm) & $0.09 \pm 0.006$ & $0.08-0.09$ & 5 \\
\hline Mercury (ppm) & $<0.02$ & - & 5 \\
\hline Selenium (ppm) & $0.31 \pm 0.096$ & $0.18-0.40$ & 5 \\
\hline Aflatoxins (ppb) & $<5.00$ & - & 5 \\
\hline Nitrate nitrogen $(\mathrm{ppm})^{\mathrm{c}}$ & $14.6 \pm 6.6$ & $5.09-23.7$ & 5 \\
\hline Nitrite nitrogen $(\mathrm{ppm})^{\mathrm{c}}$ & $1.34 \pm 1.34$ & $0.30-3.04$ & 5 \\
\hline BHA $(\mathrm{ppm})^{\mathrm{d}}$ & $<1.0$ & - & 5 \\
\hline BHT $(\mathrm{ppm})^{\mathrm{d}}$ & $<1.0$ & - & 5 \\
\hline Aerobic plate count (CFU/g) & $10 \pm 0.0$ & 10 & 5 \\
\hline Coliform (MPN/g) & $3.0 \pm 0.0$ & 3.0 & 5 \\
\hline Escherichia coli (MPN/g) & $<10$ & - & 5 \\
\hline Salmonella (MPN/g) & Negative & - & 5 \\
\hline Total nitrosoamines $(\mathrm{ppb})^{\mathrm{e}}$ & $4.0 \pm 1.66$ & $2.2-5.8$ & 5 \\
\hline$N$-Nitrosodimethylamine (ppb) ${ }^{\mathrm{e}}$ & $2.0 \pm 1.29$ & $1.0-4.0$ & 5 \\
\hline$N$-Nitrosopyrrolidine $(\mathrm{ppb})^{\mathrm{e}}$ & $2.0 \pm 0.833$ & $1.1-3.1$ & 5 \\
\hline \multicolumn{4}{|l|}{ Pesticides (ppm) } \\
\hline$\alpha-\mathrm{BHC}$ & $<0.01$ & - & 22 \\
\hline$\beta$-BHC & $<0.02$ & - & 22 \\
\hline$\gamma$-BHC & $<0.01$ & - & 22 \\
\hline$\delta$-BHC & $<0.01$ & - & 22 \\
\hline Heptachlor & $<0.01$ & - & 22 \\
\hline Aldrin & $<0.01$ & - & 22 \\
\hline Heptachlor epoxide & $<0.01$ & - & 22 \\
\hline DDE & $<0.01$ & - & 22 \\
\hline DDD & $<0.01$ & - & 22 \\
\hline DDT & $<0.01$ & - & 22 \\
\hline $\mathrm{HCB}$ & $<0.01$ & - & 22 \\
\hline Mirex & $<0.01$ & - & 22 \\
\hline Methoxychlor & $<0.05$ & - & 22 \\
\hline Dieldrin & $<0.01$ & - & 22 \\
\hline Endrin & $<0.01$ & - & 22 \\
\hline
\end{tabular}




\begin{tabular}{lccc}
\hline & Mean \pm Standard Deviation & Range & Number of Samples \\
\hline Telodrin & $<0.01$ & - & 22 \\
Chlordane & $<0.05$ & - & 22 \\
Toxaphene & $<0.10$ & - & 22 \\
Estimated PCBs & $<0.20$ & - & 22 \\
Ronnel & $<0.01$ & - & 22 \\
Ethion & $<0.02$ & - & 22 \\
Trithion & $<0.05$ & - & 22 \\
Diazinon & $<0.10$ & - & 22 \\
Methyl chlorpyrifos & $0.068 \pm 0.015$ & - & 5 \\
Methyl parathion & $<0.02$ & - & 22 \\
Ethyl parathion & $<0.02$ & $-0.074-0.581$ & 5 \\
Malathion & $0.273 \pm 0.186$ & - & 22 \\
Endosulfan I & $<0.01$ & - & 22 \\
Endosulfan II & $<0.01$ & - & 22 \\
Endosulfan sulfate & $<0.03$ & & - \\
\hline
\end{tabular}

${ }^{\mathrm{a}}$ All samples were irradiated. $\mathrm{CFU}=$ colony-forming units; MPN $=$ most probable number; $\mathrm{BHC}=$ hexachlorocyclohexane or benzene hexachloride.

${ }^{b}$ For values less than the limit of detection, the detection limit is given as the mean.

${ }^{\mathrm{c}}$ Sources of contamination: alfalfa, grains, and fish meal.

${ }^{\mathrm{d}}$ Sources of contamination: soy oil and fish meal.

${ }^{\mathrm{e}} \mathrm{All}$ values were corrected for percent recovery. 


\section{Appendix H. Sentinel Animal Program \\ Table of Contents}

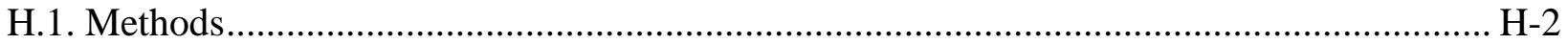

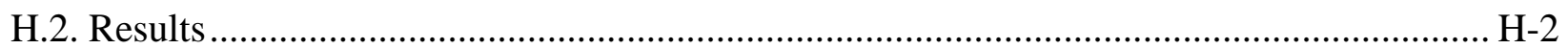

\section{Tables}

Table H-1. Laboratory Methods and Agents Tested for in the Sentinel Animal Program ......... H-2 


\section{H.1. Methods}

Rodents used in the National Toxicology Program are produced in optimally clean facilities to eliminate potential pathogens that may affect study results. The Sentinel Animal Program is part of the periodic monitoring of animal health that occurs during the toxicologic evaluation of test compounds. Under this program, the disease state of the rodents is monitored via sera or feces from extra (sentinel) or dosed animals in the study rooms. The sentinel animals and the study animals are subject to identical environmental conditions. Furthermore, the sentinel animals come from the same production source and weanling groups as the animals used for the studies of test compounds.

Blood samples were collected and allowed to clot, and the serum was separated. All samples were processed appropriately and tested at BioReliance Corporation, Rockville, MD, for determination of the presence of pathogens. The laboratory methods and agents for which testing was performed are tabulated below; the times at which samples were collected during the studies are also listed.

Table H-1. Laboratory Methods and Agents Tested for in the Sentinel Animal Program

\begin{tabular}{|c|c|}
\hline Method and Test & Time of Collection \\
\hline \multicolumn{2}{|l|}{ Rats } \\
\hline \multicolumn{2}{|l|}{ ELISA } \\
\hline PVM (pneumonia virus of mice) & 1 and 4 weeks, study termination \\
\hline RCV/SDA (rat coronavirus/sialodacryoadenitis virus) & 1 and 4 weeks, study termination \\
\hline Sendai & 1 and 4 weeks, study termination \\
\hline \multicolumn{2}{|l|}{ Immunofluorescence Assay } \\
\hline Parvovirus & 1 and 4 weeks, study termination \\
\hline \multicolumn{2}{|l|}{ Mice } \\
\hline \multicolumn{2}{|l|}{ ELISA } \\
\hline Ectromelia virus & 1 and 4 weeks, study termination \\
\hline EDIM (epizootic diarrhea of infant mice) & 1 and 4 weeks, study termination \\
\hline GDVII (mouse encephalomyelitis virus) & 1 and 4 weeks, study termination \\
\hline LCM (lymphocytic choriomeningitis virus) & 1 and 4 weeks, study termination \\
\hline Mouse adenoma virus-1 & 1 and 4 weeks, study termination \\
\hline MHV (mouse hepatitis virus) & 1 and 4 weeks, study termination \\
\hline MMV (mouse minute virus, viral protein 2) & 1 and 4 weeks, study termination \\
\hline MPV (mouse parvovirus, viral protein 2) & 1 and 4 weeks, study termination \\
\hline PVM & 1 and 4 weeks, study termination \\
\hline Reovirus 3 & 1 and 4 weeks, study termination \\
\hline Sendai & 1 and 4 weeks, study termination \\
\hline \multicolumn{2}{|l|}{ Immunofluorescence Assay } \\
\hline MMV & Study termination \\
\hline GDVII & Study termination \\
\hline
\end{tabular}

\section{H.2. Results}

All test results were negative. 


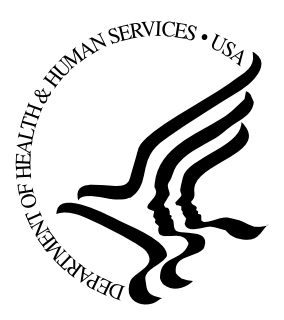

\title{
National Toxicology Program
}

\author{
NTP Central Data Management, MD EC-03
}

National Institute of Environmental Health Sciences

P.O. Box 12233

Research Triangle Park, NC 27709

http://ntp.niehs.nih.gov 